\title{
Republic of Slovenia: Selected Issues
}

This Selected Issues paper for the Republic of Slovenia was prepared by a staff team of the International Monetary Fund as background documentation for the periodic consultation with the member country. It is based on the information available at the time it was completed on May 2, 2007. The views expressed in this document are those of the staff team and do not necessarily reflect the views of the government of the Republic of Slovenia or the Executive Board of the IMF.

The policy of publication of staff reports and other documents by the IMF allows for the deletion of market-sensitive information.

To assist the IMF in evaluating the publication policy, reader comments are invited and may be sent by e-mail to publicationpolicy@imf.org.

Copies of this report are available to the public from

International Monetary Fund $\bullet$ Publication Services

$70019^{\text {th }}$ Street, N.W. • Washington, D.C. 20431

Telephone: (202) 623-7430 • Telefax: (202) 623-7201

E-mail: publications@imf.org • Internet: http://www.imf.org

Price: $\$ 18.00$ a copy

\section{International Monetary Fund \\ Washington, D.C.}





\title{
INTERNATIONAL MONETARY FUND
}

\section{REPUBLIC OF SLOVENIA}

\author{
Selected Issues \\ Prepared by Anita Tuladhar, Rudolfs Bems (both EUR), \\ and Jochen Andritzky (MCM) \\ Approved by European Department
}

May 2, 2007

Contents

Page

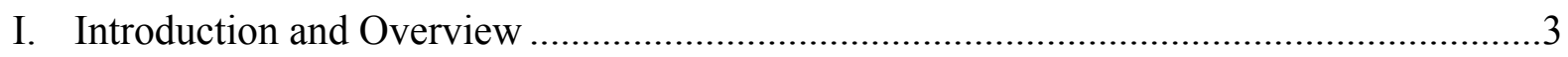

II. Efficiency of Slovene Banking Sector in the EU Context..............................................

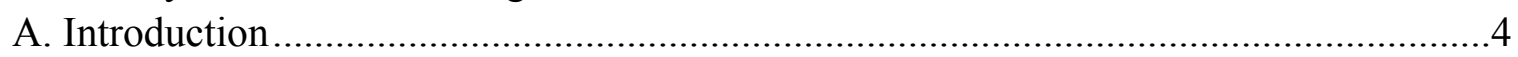

B. Qualitative Indicators of Bank Efficiency.................................................................

C. Estimates of the Distance of Slovene Banks from a Cost Efficiency Frontier ............... 7

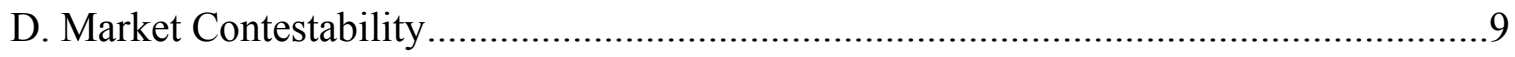

E. Determinants of Efficiency and Contestability and Policy Issues................................12

Tables

1. Summary of Stochastic Frontier Estimates of Cost Functions ......................................14

2. Details of Baseline Regression Results for Market Contestability ................................14

3. Baseline Competitiveness Index and Tests of Long-Run Equilibrium...........................15

Appendix

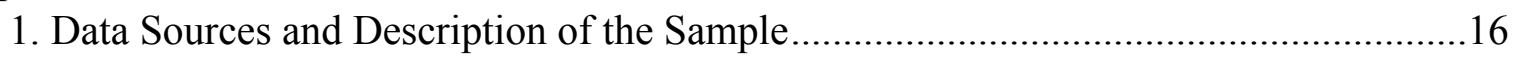

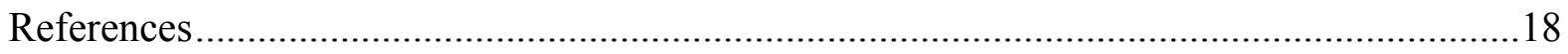

III. Bank Risks from Cross-Border Lending and Borrowing in Slovenia ..............................19

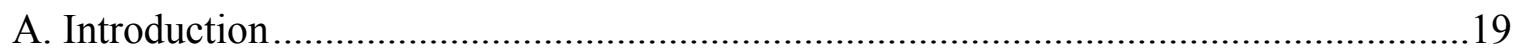

B. Extent of Cross-Border Lending and Borrowing ......................................................2

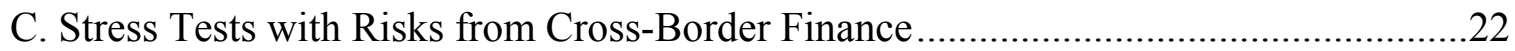

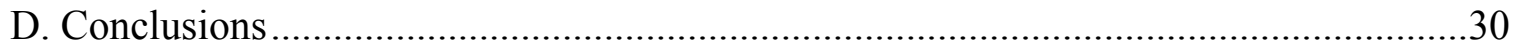

Box

1. Foreign Expansion of Nova Ljubljanska Banka (NLB) ..............................................22 
Figure

1. Foreign Bank and Portfolio Investment by Residence of Investor, 2005

Appendix

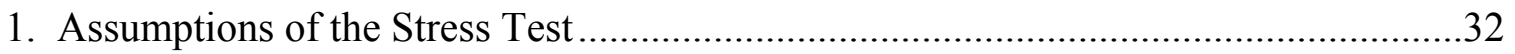

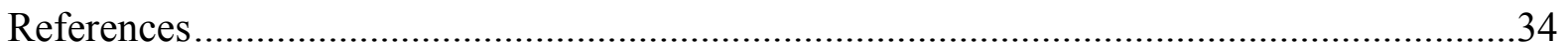

IV. Issues with Capital Market Development in Slovenia..................................................35

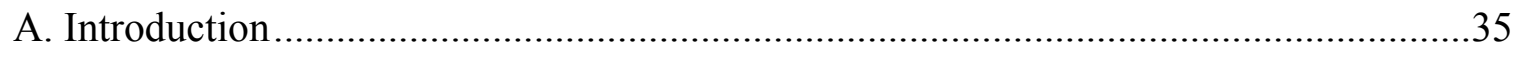

B. State of Development of the Slovene Capital Markets ...........................................36

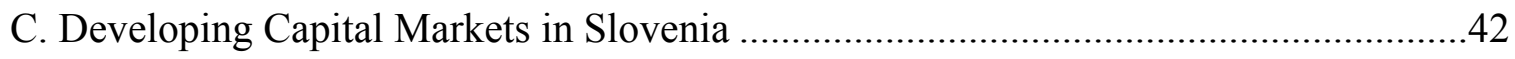

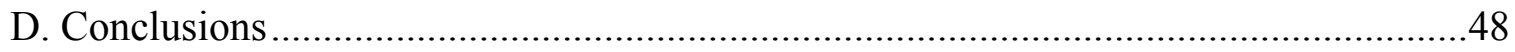

Boxes

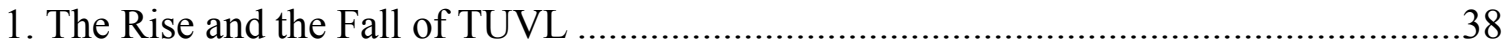

2. SME Securitization: The Spanish Case .....................................................................46

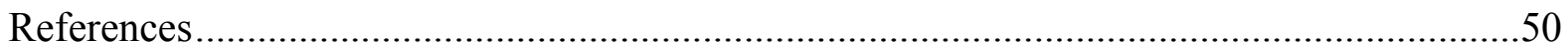

V. A Fiscal Framework for Slovenia .........................................................................51

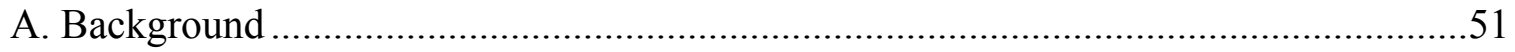

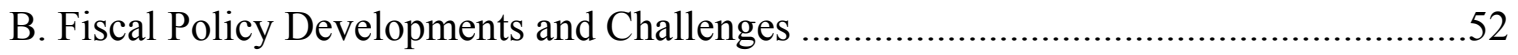

C. The Current Fiscal Framework in Slovenia ..............................................................56

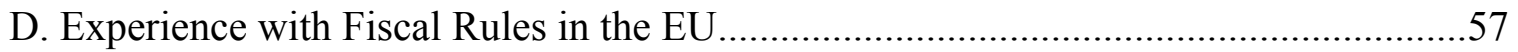

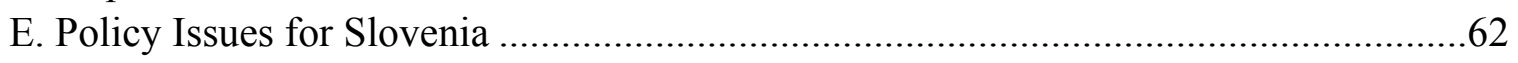

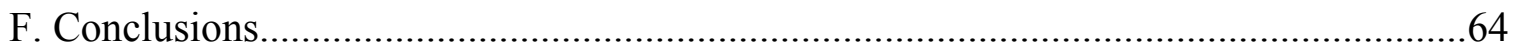

Figures

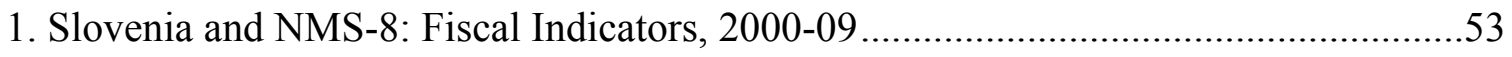

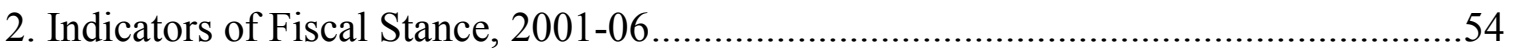

Tables

1. Deficit Target Rules in Select EU Countries .......................................................58

2. Key Features of Expenditure Rules in Select Countries ..............................................60

3. Key Features of Independent Fiscal Institutions in Select Countries .........................62

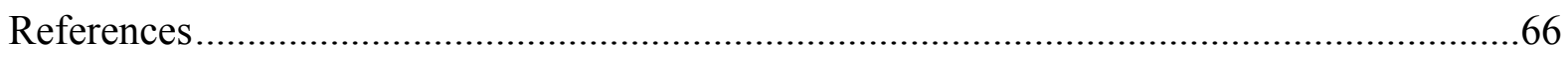




\section{INTRODUCTION AND OVERVIEW}

1. While Slovenia's economy is presently doing well, it faces several challenges in the coming years. In the financial sector, growing EU financial integration raises questions about vulnerabilities from increasing cross-border activities and about the ability of the statedominated banking sector to deal with greater competition. Also, the relatively low level of development of Slovene capital market compared to EU peers may constrain growth and opportunities for diversification of risk. As for fiscal policy, the rigid structure of public spending limits Slovenia's ability to adjust to shocks and meet medium-term fiscal targets in the face of declining revenues as a result of the ongoing tax reform.

2. This paper looks into these challenges and how they can be met. Specifically, the following four issues will be covered: (i) how efficient is the Slovene banking sector in the EU context and how contestable is the market; (ii) to what extent has the rapid rise in crossborder financial flows increased vulnerabilities in Slovene banks; (iii) what is the state of development of Slovene capital markets and how can the contribution of these markets to growth and financial stability be enhanced; and (iv) how could the fiscal institutional framework be strengthened to advance expenditure reform and preserve fiscal discipline?

3. To face the challenges of increasing EU financial integration, Slovene banks need to improve efficiency and profitability. Using both qualitative and quantitative empirical analysis, Chapter II finds that Slovene banks are among the least efficient in Europe, which can reflect low contestability compared to EU peers. Efficiency and contestability may have been influenced by market concentration and ownership. As state banks are the least efficient, privatization and other measures to increase bank efficiency could have important benefits.

4. Slovene banks' rapidly expanding cross-border borrowing and lending warrants close monitoring of underlying vulnerabilities. Chapter III examines recent trends in foreign funding of Slovene banks and their exposures in the region, and using stress tests, assesses their resiliency to shocks. While stress tests do not point to high vulnerabilities, information on foreign credit exposure could be improved.

\section{Deepening of capital markets could improve efficiency of financial}

intermediation. Chapter IV shows that the Slovene equity and bond markets remain narrow and illiquid offering limited investment opportunities. To deepen the capital market, a hybrid strategy should be pursued that seeks integration with international capital markets while continuing to enhance domestic markets tailored to local needs.

\section{A stronger fiscal framework could help Slovenia preserve the discipline and} credibility in implementing its fiscal reform program. Chapter IV discusses the experiences in the EU with medium-term expenditure frameworks and how to strengthen Slovenia's framework. Given the need for an expenditure-based consolidation to achieve the fiscal targets, an expenditure rule should be considered. 


\section{EFFiciency OF Slovene Banking Sector In THE EU CONTEXT ${ }^{1}$}

\section{Summary}

- $\quad$ The Slovene banking sector is dominated by a few large, state-owned banks and has low profitability by regional standards. Its performance will be increasingly tested by deepening EU financial integration and capital market development.

- $\quad$ To assess Slovene banks' readiness to face these challenges, the paper analyzes bank efficiency and contestability in Slovenia. It finds that Slovene banks are among the least efficient in Europe, which can reflect the low contestability compared to EU peers. Efficiency and contestability may have been influenced by market concentration and ownership.

- $\quad$ As state banks are the least efficient, privatization and other measures to increase banks efficiency could have important benefits.

\section{A. Introduction}

7. European integration poses new challenges for Slovene banks. The sector remains dominated by domestic, largely state-controlled banks. Competition has increased recently because of the presence of smaller foreign-owned banks and deepening integration with European financial markets since EU accession in 2004 and euro adoption in 2007. As a result, interest margins are declining, which, together with the loss of exchange rate revenues, is squeezing the already regionally low profitability. This raises questions about the efficiency of the Slovene banking sector in the European context, market contestability, and the ability of Slovene banks to function in a more competitive integrated market.

8. To assess Slovene banks' readiness to face these challenges and identify potential policy measures, the paper analyzes how efficient Slovene banks are in the EU context. Using detailed bank-specific data, the paper develops quantitative and qualitative indicators of bank efficiency and market contestability for Slovenia and compares them with regional competitors.

\section{Results show that the performance of the Slovene banking sector is lagging its} regional rivals. Slovene banks are on average less efficient and less profitable than those in the EMU and new member states (NMS), and the sector is among the least contested in Europe. Although the paper does not estimate determinants of efficiency and contestability, possible explanations can be the dominance of one large bank and the important share of state ownership in the sector, especially given that the large state-dominated banks are the

\footnotetext{
${ }^{1}$ Prepared by Rudolfs Bems (EUR).
} 
least efficient. This situation points to potentially large benefits from further privatization and measures to enhance local market competition.

10. The paper is organized as follows. Section B analyzes indicators of bank efficiency by comparing performance indicators for banks in Slovenia, EMU and NMS. Section C presents results from cross-country econometric estimates of banking sector cost efficiency, while Section D reports results from estimates of cross-country banking sector contestability. Finally, Section E discusses determinants of efficiency and contestability.

\section{B. Qualitative Indicators of Bank Efficiency}

11. The analysis covers commercial banks in Slovenia and in comparable EMU and NMS countries. The choice of appropriate comparators is crucial, as indicators of bank structure and performance vary systematically with factors such as the size of the market and bank's core business (ECB, 2006). To address such concerns, the study is limited to commercial banks in the smaller EMU markets and in the NMS. ${ }^{2}$ Slovene commercial banks are divided into two groups - the three largest state-dominated banks and all other.

\section{The study draws on bank-level balance sheet and income statement data from}

the BankScope database. Given the difficulties in evaluating and comparing bank performance from a single perspective, the study relies on both qualitative assessment of banking sectors' structure and performance, and quantitative estimates of banking sector cost efficiency and contestability. Because of limited availability of historical data, the main emphasis is on cross-section comparisons rather than time trends. For further details on the sample data see Appendix I.

\section{Cost indicators point to Slovenia's lagging behind} comparators in improving its relatively low efficiency. Cost-to-income ratios in the NMS have been falling toward EMU levels in recent years, as banks are increasing efficiency. In Slovenia, these ratios have remained higher, especially in the three largest, state-dominated banks. ${ }^{3}$ Other cost-efficiency indicators, such as the ratio of noninterest expenses to average assets, show a similar pattern. However, this result may be biased by the large differences in total banking sector asset size between the groups.

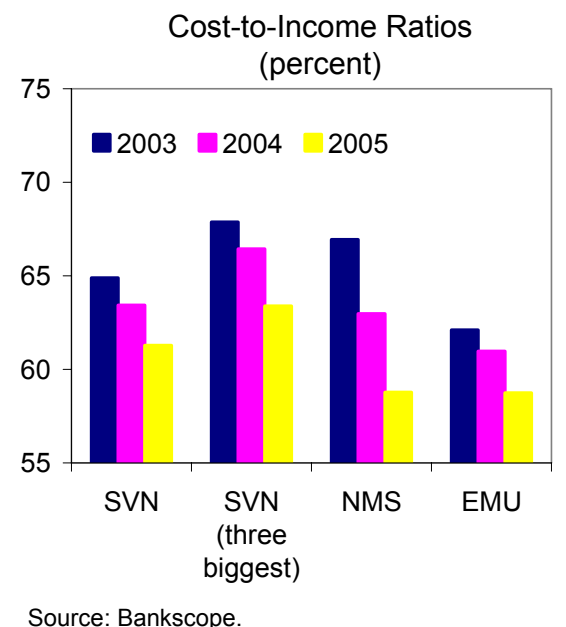

\footnotetext{
${ }^{2}$ The excluded larger EMU markets are Germany, Italy, France, and Luxembourg. NMS include the Czech Republic, Hungary, Poland, the Slovak Republic, Estonia, Latvia, and Lithuania. Slovenia is excluded from both groups. Unless noted otherwise, these definitions of EMU and NMS are followed throughout the paper.

${ }^{3}$ Measured by asset size, these banks constitute 60 percent of the Slovene banking sector.
} 


\section{The higher cost-to-income ratios in Slovenia are}

driven by labor costs. The share of labor costs in total costs in both the NMS and Slovenia has increased in recent years. While the share in the NMS remains at 80 percent of EMU levels, in Slovenia it is only 5 percent below the EMU average. ${ }^{4}$ In general, this is to be expected, because, when income and wages in NMS catch up with those in the EMU, labor costs shares should also converge. However, in Slovenia the large labor cost share points to overstaffing as wages remain regionally low. Personnel expenses per employee in Slovenia in 2005 were about one third of those in the EMU and broadly similar to those in the NMS. This suggests that the Slovene banking sector is overstaffed in a regional comparison - despite low wages, the labor share in operating costs is already at the level of the EMU average. Cost efficiency problems are also more pronounced in the three largest statedominated banks.
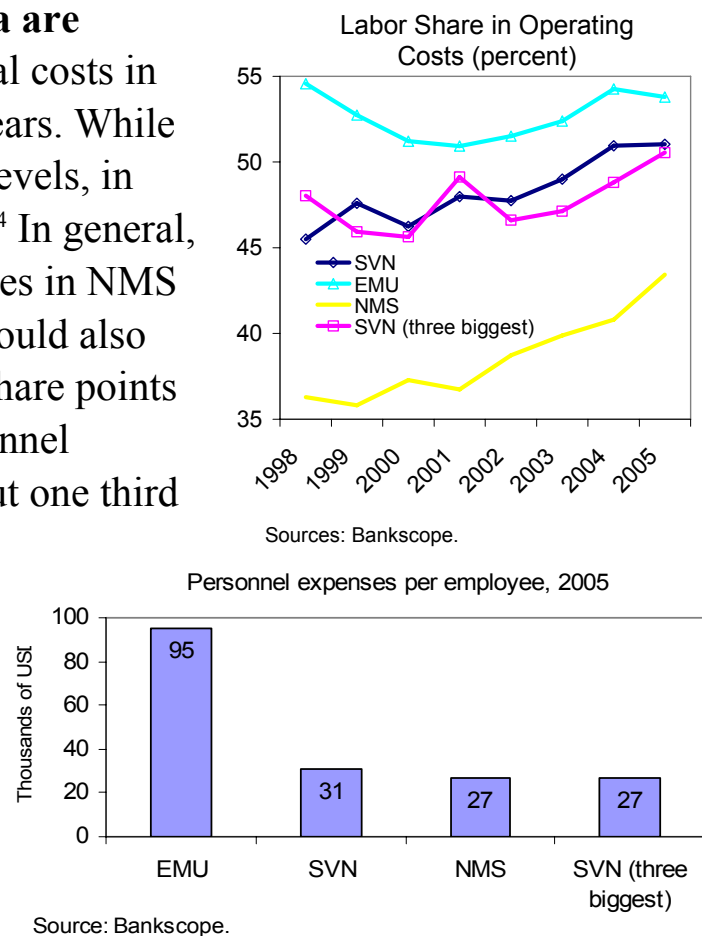

\section{Profitability indicators also show that Slovene banks lag regional comparators.}

The share of pre-tax profits in total operating income and the return on average equity (ROAE) in Slovenia was considerably lower than in the NMS and the EMU in 2005, and showed no increase from previous years. This is partly explained by stricter regulations on loan loss provisions in Slovenia until 2006, when the adoption of International Financial
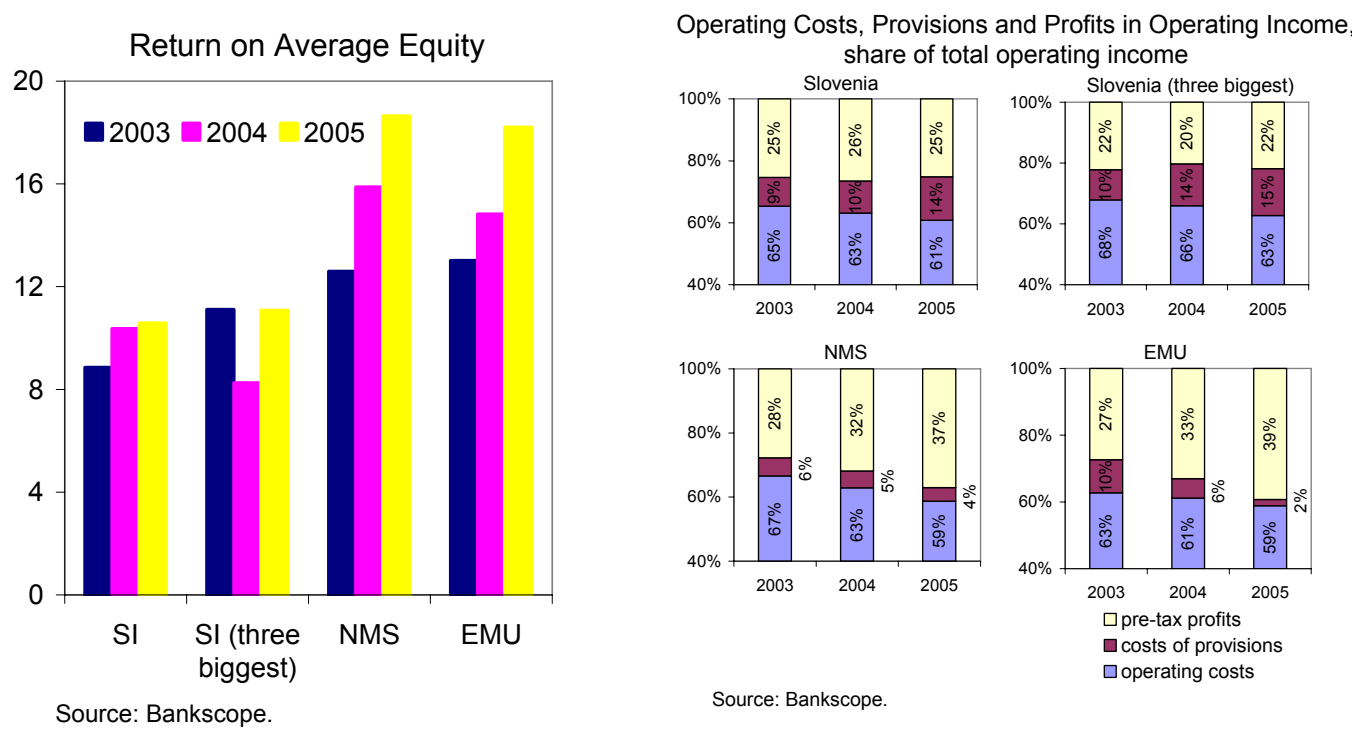

\footnotetext{
${ }^{4}$ Labor cost share and its trend for Slovenia in Bankscope data are very similar to what is reported in Bank of Slovenia (2006). The latter is based on the aggregated banking sector balance sheet for Slovenia.
} 
Reporting Standards (IFRS) harmonized provisioning rules. Preliminary estimates show that provisions in Slovene banks decreased from 13 to 8 percent of operating income during 2005-06. However, profitability in 2006 still remained below EMU and NMS levels.

16. Profits in Slovenia have been affected by declining net interest margins. While these have been broadly flat over the past five years in the EMU and the NMS, they have declined in Slovenia over the same period by around 2 percentage points. This can mean that competition has only recently increased in Slovenia when it joined the EU in 2004 and after interest rates started to converge toward EU levels in anticipation of euro adoption in 2007. By end-2006, net interest margins in Slovenia had decreased further, but remained about 1 percentage point above the EMU average. This suggests that pressure on profitability of Slovene banks will continue.
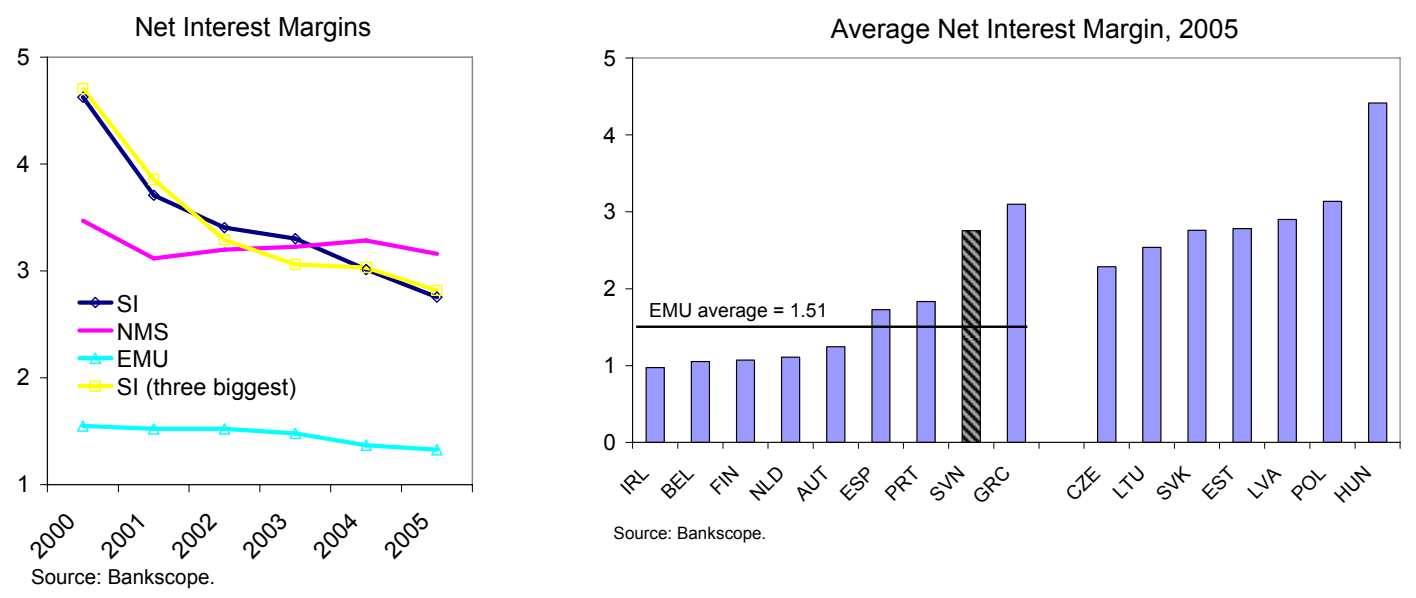

17. In sum, these indicators suggests that the Slovene banking sector is less efficient and profitable than its regional rivals. The problems appear more pronounced in the larger state-dominated banks. The still high interest margins suggest that poor performance may reflect problems with market contestability. To complement these simple comparisons of cost efficiency and profitability, bank efficiency in Slovenia is also analyzed econometrically. This allows for a better control for the impact of size, input costs and business models on performance.

\section{Estimates of the Distance of Slovene Banks from a Cost Efficiency Frontier}

\section{Banking sector efficiency can be assessed by a stochastic "best practices"}

frontier analysis. This approach estimates indirect levels of costs for a given level of outputs and prices of inputs. ${ }^{5}$ In line with intermediation approach to banking, assumes that bank's output, represented by interest earning assets, is produced using labor, capital and funds as

\footnotetext{
${ }^{5}$ The method builds on the assumption that all banks in the sample face a common production function. For further details on stochastic frontier analysis methodology, see Kumbhakar and Lovell (2000).
} 
inputs. One can then define a total cost frontier, characterized by $T C_{i}=f\left(Y_{i}, p_{i}{ }^{k}\right)$, where $p_{i}{ }^{k}$ is a vector of input prices and $Y_{i}$ represents outputs. Total cost equation is used to estimate the cost frontier for the whole sample and distance from the frontier for each of the sample banks.

\section{Benchmark estimates are based on the following specification:}

$$
\ln T C_{i}=\alpha+\sum_{j=\{K, L, F\}} \beta^{j} \ln p_{i}^{j}+\delta \ln Y_{i}+v_{i}+u_{i}
$$

where $Y_{i}$ is output captured with total earning assets; $p^{L}$ is personnel expenses divided by the number of employees and is a proxy for the price of labor; $p^{K}$ is other operating and administrative expenses divided by fixed assets and is a proxy for the input price of equipment and fixed capital; $p^{F}$ is interest expenses divided by all funding and proxies the price of funding; and $T C_{i}$ is total costs obtained as the sum of interest expenses and total operating expenses. ${ }^{6}$ The error term consists of two components: a two-sided random noise component, $v_{i}$, and nonnegative cost efficiency component, $u_{i}$. The measure of cost efficiency is provided by $C E_{i}=\exp \left\{-u_{i}\right\}$, where $C E_{i}=1$ represents the efficiency frontier. The specification imposes homogeneity in prices by normalizing input prices with the price of funds, $p_{i}^{F}$. To minimize heteroscedasticity in the error term, output and total costs are normalized with equity.

\section{The results confirm that Slovene banks are on average less efficient than those in} the EMU and NMS (left panel in text figure and Table 1). The estimation also shows that there are no clear differences in efficiency between EMU and NMS banks.

\footnotetext{
${ }^{6}$ These definitions of regression variables are standard in the literature. The only notable deviation is the definition of the price of labor. General practice in the literature, due to lack of data on employment, has been to express it as personnel expenses over total assets. Although using data on employment meant a somewhat smaller number of observations, correlations between the price of labor expressed using the two methods were close to zero, and, therefore, the series with a more appealing economic interpretation was chosen.
} 
Average Bank Efficiency Scores by Country, 2005

(Distance from cost frontier, frontier=1)

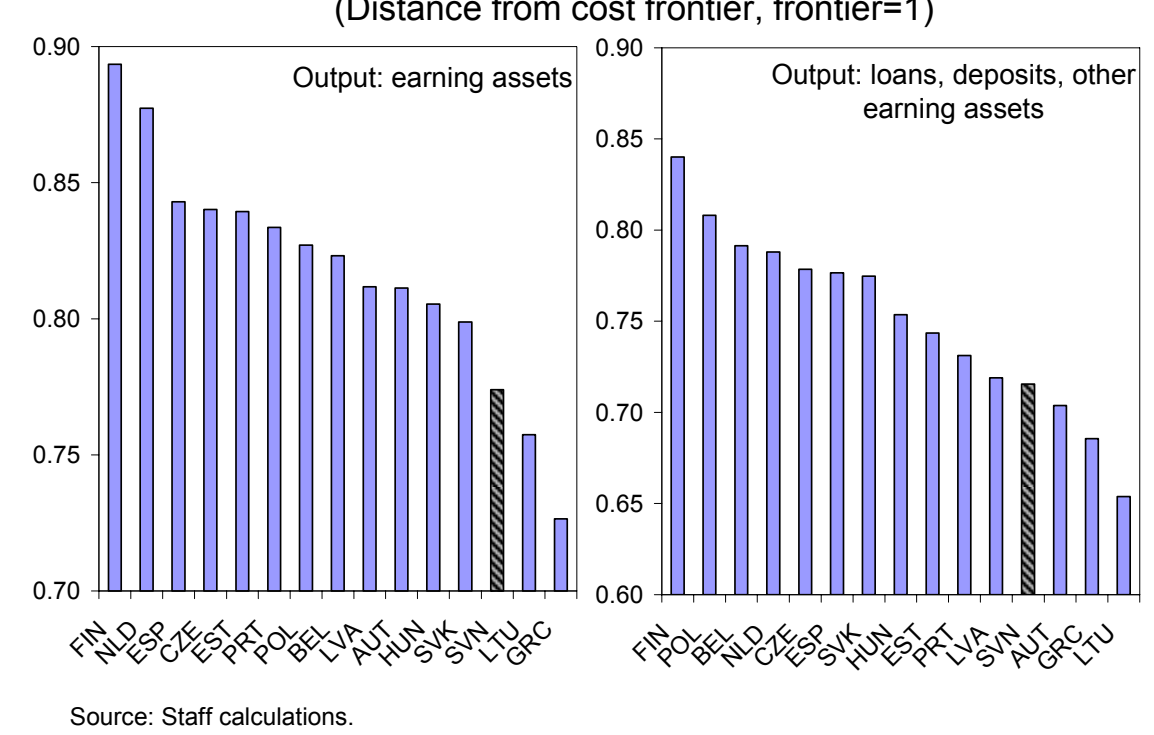

\section{The results are robust to alternative model assumptions and regression}

specifications. The results are broadly unchanged with an alternative specification for the production function, whereby the output of the sector is characterized by loans, deposits, and other earning assets rather than by earning assets alone (right panel of text figure). ${ }^{7}$ A common cost frontier was also estimated for 2000-05 using time dummies for each year and showed similar results for average banking sector efficiency. Other specifications examined included (i) separate cost frontier estimates for the NMS and the EMU; (ii) the addition of loans/assets, deposits/assets and equity/assets ratios as control variables; (iii) the inclusion/exclusion of commission and fees from interest income and expenses; and (iv) the normalization of the price of capital with fixed or total assets. These all gave broadly similar results about banking sector efficiency in Slovenia.

22. The estimates are also consistent with other efficiency indicators. Cost-to-income ratios already showed that Slovene banks are on average less efficient than banks in the NMS and the EMU, while in general there is no clear difference between the two regions. Also, in line with results from the previous section, the average efficiency in the three biggest Slovene banks is below the banking sector average.

\section{Market Contestability}

23. Market contestability is analyzed using an index that measures the extent of the pass-through of changes in input prices to revenues in banks. The methodology was developed by Panzar and Rosse (1987) (hereafter PR), who measure contestability based on a

\footnotetext{
${ }^{7}$ With more than one output variable, the regression equation takes a translog form.
} 
concept that, under certain assumptions ${ }^{8}$, bank revenues under perfect competition increase by the same amount as input prices, with output quantity staying constant and output prices increasing proportionally. With less-than-perfect competition, the pass-through to output prices is less than one-to-one and decreases with lower competition. Thus, market contestability is measured by an estimate of the response of output prices to changes in input prices. This methodology is then used to estimate a competitiveness index for each market in the sample, and markets are ranked according to contestability. In line with benchmark estimates of market efficiency, the study assumes that banks are in the business of producing interest-earning assets using capital, labor, and interest-bearing funds as inputs. Based on the banks' revenue equation, the contestability of the market can then be inferred from the $H$ statistic, which measures the extent to which changes in factor prices are reflected in revenues. If the $H$-statistic assumes a value of 1 , the market is perfectly competitive, while, in case of monopolistic competition, the values of the $H$-statistic are between 0 and 1.

\section{The benchmark estimates of market contestability are based on the following specification:}

$$
\ln p_{i t}^{Y}=a+\beta^{L} \ln p_{i t}^{L}+\beta^{K} \ln p_{i t}^{K}+\beta^{F} \ln p_{i t}^{F}+\varepsilon_{i t},
$$

where $p^{Y}$ is interest income divided by all earning assets and proxies the price of bank output; $p^{L}, p^{K}$, and $p^{F}$ are input prices already defined in the previous section; and the $H$ statistic is defined by $H=\sum_{j=\{L, K, F\}} \beta^{j}$.

\section{Results show that the Slovene} banking sector is among the least contested among the EMU and NMS. For the total sample period, 1995-2005, market contestability was the lowest in Slovenia and several NMS (Lithuania, Hungary, and Slovak Republic), and EMU markets were generally more competitive, with Belgium, Austria, and the Netherlands having the highest scores. Further details are presented in Tables 2 and 3.

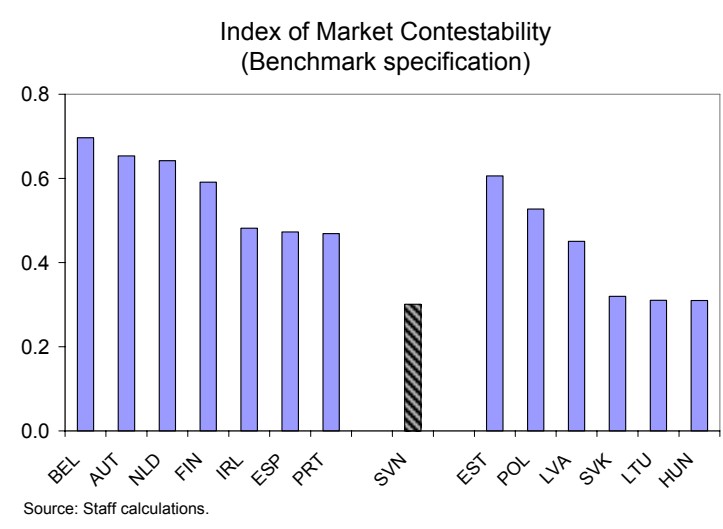

\footnotetext{
${ }^{8} \mathrm{PR}$ methodology assumes, among other things, that bank cost structure is homogenous and banks operate in a long-run equilibrium with exogenous input prices. For a more detailed discussion of underlying assumptions, see, e. g., Bikker and Haaf (2002). This paper tests for the presence of long-run equilibrium in each market with an approach previously used in the literature (see, e.g., Claessens and Laeven (2004)). Results of the long-run equilibrium test are reported in Table 3.
} 


\section{The results are robust to alternative specifications of the revenue function and}

other alterations. Robustness was tested by (i) adding time dummies and loans/assets deposits/assets and equity/assets ratios as control variables; ${ }^{9}$ (ii) including commission and fee income in the calculation of the price of funds and output; (iii) changing the normalization of the price of capital from fixed assets to total assets; and (iv) performing estimates with OLS and GLS with fixed bank-specific effects. Each of the resulting 16 specifications has its appeal. Although results for several banking sectors exhibited significant variations, the majority of the specifications showed that the Slovene banking sector was among the least contested in Europe. Also, in line with the baseline results, the average contestability index was higher in the EMU than in the NMS. ${ }^{10}$ The results were also robust to a shortening of the sample period to 1999-2005.

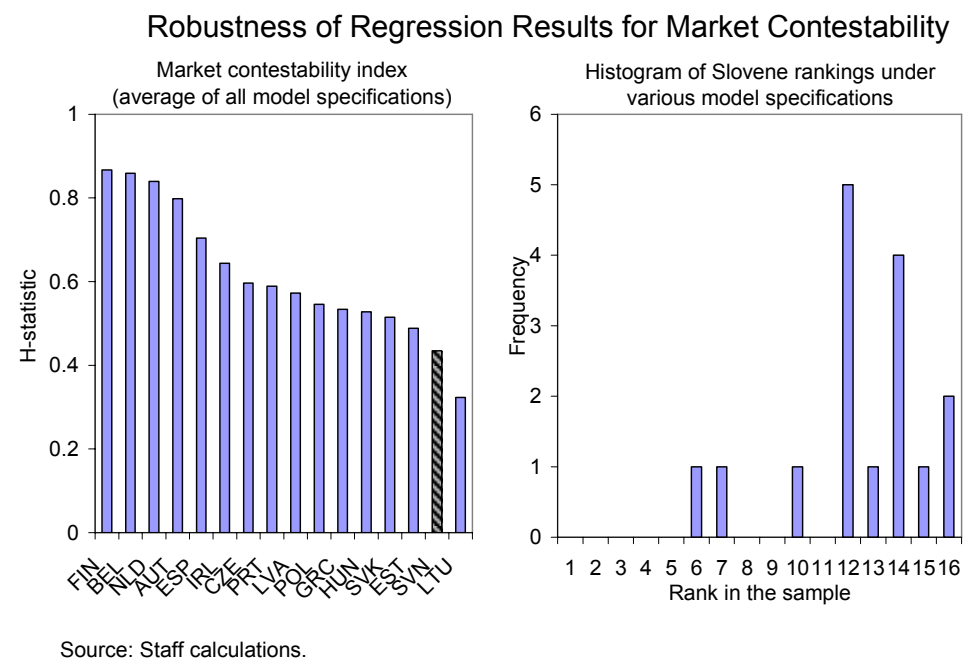

27. Tests detect no significant variation in contestability over time. Given the limited number of observations for each year, estimates of an annual trend in contestability index are not feasible. However, estimates for three subperiods with time dummies - 1995-99, 2000-02 and 2003-05 - show no evidence of a statistically significant variation in the $H$-statistic. This is somewhat surprising, as one would expect that greater competition from deepening EU integration would have increased contestability in Slovenia. This outcome can, however, reflect the fact that the sample ends in 2005, and the financial integration has accelerated only recently.

28. The findings are consistent with similar estimates in the literature. Bikker and others (2006) report $H$-statistics for a large set of countries, including the EMU and the NMS, that show that Slovenia ranks low in contestability $-10^{\text {th }}, 14^{\text {th }}$ and $15^{\text {th }}$ out of 16 , depending on the model specification. Their results also confirm that market contestability in the EMU is greater than in the NMS and that Slovenia lags both country groups.

\footnotetext{
${ }^{9}$ Our baseline specification already includes the absolute size of assets as a control, since the price of bank output is expressed as the ratio of revenues to all earning assets.

${ }^{10}$ In calculating the average index values and rankings, we have ignored long-run equilibrium test results. For Slovenia, existence of a long-run equilibrium was not rejected in any of the specifications.
} 


\section{E. Determinants of Efficiency and Contestability and Policy Issues}

\section{The results raise questions about the determinants of efficiency and}

contestability. Data limitation did not allow testing for this formally for Slovenia. However, simple correlations show a negative correlation of -0.74 between the contestability index and the net interest margin of a banking sector, and a positive correlation of 0.61 between the estimates of contestability and cost efficiency. This points to a possible link between efficiency and contestability, in that lack of competition would have led to low efficiency.

30. Market entry and activity restrictions, structure of ownership, bank size, and market concentration have been the main determinants of bank efficiency and contestability in larger cross-country studies. ${ }^{11}$ Although some of the empirical findings are conflicting, the studies have generally found that market entry and activity restrictions reduce market contestability and, thereby, efficiency. State ownership is also found to have a negative effect on bank efficiency and market contestability, while the opposite holds for foreign ownership. Bank size and market concentration also affect efficiency and contestability negatively, although the empirical evidence here is less clear cut.

31. The Slovene banking sector has faced many of these constraints, which may have contributed to low efficiency and contestability. The share of direct and indirect state ownership of banks in Slovenia is high by regional standards. For example, the government owns directly 35 percent of the largest bank, while it holds indirectly another 16 percent through state-owned investment funds and nonbank corporations. The Slovene banking sector is also highly concentrated, with one large, state-controlled bank accounting for 40 percent of total assets - one of the highest ratios in Europe. The Herfindahl index ${ }^{12}$ for 2005 also ranks Slovenia as the $6^{\text {th }}$ most concentrated among 16 sample countries $(\mathrm{ECB}$, 2006). This situation may have discouraged bank entry and limited competition in the sector.

32. Improving the efficiency and contestability of banks in Slovenia would enhance growth and financial stability. As growth is becoming increasingly dependent on productivity, a more contestable and efficient banking sector that intermediates finance to the most efficient uses is important for competitiveness and continued convergence toward EMU income levels. Given the underperformance of the sector to date, with greater efficiency its contribution to growth can be substantial. ${ }^{13}$ A more efficient banking sector can also better

\footnotetext{
${ }^{11}$ See, e.g., Bikker and Haaf (2002), Gelos and Roldos (2002), Micco, Panizza, and Yanez (2004), and Claessens and Laeven (2004). Berger and others (2004) provide a detailed survey of the relevant literature.

${ }^{12}$ Calculated as $H=\sum\left(s_{i j} \cdot 100\right)^{2}$, where $s_{i j}$ represents total assets of bank i in country $\mathrm{j}$ as a share of country j total bank assets.

${ }^{13}$ As a reference, further financial integration within EMU is estimated to add 1 percentage point to GDP growth over the next 10 years (Giannetti and others 2002).
} 
deal with a rapidly aging population by providing more sophisticated financial products for pension savings. Greater efficiency and profitability would also help reduce vulnerabilities stemming from credit and market risks. ${ }^{14}$

\section{Going forward, European integration, capital market development, and the role} of the state will all be important for the performance of banks. Deeper EU integration and capital market development will no doubt add to competitive pressures and force Slovene banks to improve efficiency. The government is also planning to further privatize banks, which can enhance efficiency and profitability. However, as the government is keen to retain majority shares in the key banks, more active measures may be needed to ensure that efficiency continues to improve. Measures, for example, to raise corporate governance standards to EU levels for board members, define a longer-term growth strategy in banks in which the state remains a dominant shareholder, and to list these banks in the stock exchange, can increase management accountability and transparency of operations. Strong bank supervision should also be maintained to monitor bank performance and risks.

\footnotetext{
${ }^{14}$ See Chapter III on "Bank Risks from Cross-Border Lending and Borrowing in Slovenia."
} 
Table 1. Summary of Stochastic Frontier Estimates of Cost Functions

\begin{tabular}{lcc}
\hline & $\begin{array}{c}\text { Assumed Bank Output: } \\
\text { Earning Assets }\end{array}$ & $\begin{array}{c}\text { Assumed Bank Output: } \\
\text { Loans, Deposits, Other } \\
\text { Earning Assets }\end{array}$ \\
\hline Log likelihood & -2.42 & -74.7 \\
sigmaU/sigmaV & $2.68(0.04)$ & $2.23(0.08)$ \\
sigma2 & $0.14(0.02)$ & $0.26(.004)$ \\
sigmaU2/sigma2 & 0.878 & 0.832 \\
Mean efficiency & 0.826 & 0.756 \\
\hline
\end{tabular}

Sources: Bankscope; and staff calculations.

Notes: Log likelihood reports the value of log likelihood function; sigmaU is standard deviation of the inefficiency component of disturbance: sigmaV is standard deviation of the random component of disturbance; sigma2 is variance of the composite disturbance; where applicable standard errors are shown in parentheses.

Table 2. Details of Baseline Regression Results for Market Contestability

\begin{tabular}{lcccccccccc}
\hline Country & $\beta F$ & $\mid t$-stat $\mid$ & $\beta L$ & $\mid t$-stat $\mid$ & $\beta K$ & $\mid t$-stat $\mid$ & Const & $\mid t$-stat $\mid$ & No. of obs. & $R 2$ \\
\hline AUT & 0.64 & $18.84^{* *}$ & 0.00 & 0.09 & 0.01 & 0.44 & -0.82 & $3.83^{* *}$ & 192 & 0.66 \\
BEL & 0.67 & $11.88^{* *}$ & -0.01 & 0.29 & 0.04 & 1.66 & -0.70 & $2.75^{* *}$ & 170 & 0.46 \\
CZE & 0.42 & $10.19^{* *}$ & -0.28 & $4.58^{* *}$ & 0.00 & 0.12 & -0.63 & $3.67^{* *}$ & 136 & 0.61 \\
EST & 0.75 & $8.07^{* *}$ & -0.22 & $2.34^{*}$ & 0.07 & 0.98 & 0.64 & $2.33^{*}$ & 44 & 0.82 \\
ESP & 0.62 & $9.83^{* *}$ & -0.11 & 0.95 & -0.04 & 0.98 & -0.36 & 0.9 & 53 & 0.77 \\
FIN & 0.61 & $9.07^{* *}$ & -0.04 & 0.43 & 0.02 & 0.43 & -0.85 & 1.85 & 44 & 0.68 \\
GRC & 0.54 & $16.90^{* *}$ & -0.21 & $3.62^{* *}$ & -0.03 & 1 & -0.16 & 0.92 & 92 & 0.88 \\
HUN & 0.49 & $7.46^{* *}$ & -0.22 & $3.34^{* *}$ & 0.04 & 1.4 & -0.16 & 0.61 & 71 & 0.55 \\
IRL & 0.76 & $23.89^{* *}$ & -0.22 & $5.93^{* *}$ & -0.06 & $3.06^{* *}$ & 0.44 & $2.09^{*}$ & 110 & 0.86 \\
LTU & 0.59 & $9.20^{* *}$ & -0.25 & $3.75^{* *}$ & -0.03 & -0.48 & 0.06 & 0.33 & 72 & 0.82 \\
LVA & 0.65 & $14.65^{* *}$ & -0.11 & $2.38^{*}$ & -0.09 & $2.27^{*}$ & -0.08 & 0.45 & 166 & 0.65 \\
NLD & 0.74 & $28.60^{* *}$ & -0.05 & 1.09 & -0.05 & $2.98^{* *}$ & -0.32 & 1.67 & 171 & 0.86 \\
POL & 0.67 & $14.10^{* *}$ & -0.11 & $2.91^{* *}$ & -0.04 & 1.25 & -0.10 & 0.85 & 111 & 0.81 \\
PRT & 0.67 & $13.93^{* *}$ & -0.25 & $5.52^{* *}$ & 0.05 & 1.83 & 0.35 & 1.69 & 101 & 0.75 \\
SVN & 0.58 & $15.43^{* *}$ & -0.31 & $5.75^{* *}$ & 0.03 & 1.39 & 0.27 & 1.53 & 124 & 0.76 \\
SVK & 0.50 & $14.99^{* *}$ & -0.10 & $2.06^{*}$ & -0.07 & $3.62^{* *}$ & -0.77 & $7.97^{* *}$ & 102 & 0.86 \\
\hline SOur & & & & & & & & & &
\end{tabular}

Sources: Bankscope; and staff calculations.

Notes: Dependent variable: interest income to total earning assets. ${ }^{*}$ significant at 5 percent; ${ }^{* *}$ significant at 1 percent. 
Table 3. Baseline Competitiveness Index and Tests of Long-Run Equilibrium

\begin{tabular}{|c|c|c|c|c|c|}
\hline \multirow[t]{2}{*}{ Country } & \multicolumn{2}{|c|}{$\begin{array}{l}\text { Competitiveness } \\
\text { index }\end{array}$} & \multicolumn{3}{|c|}{$\begin{array}{l}\text { Test of LR Equilibrium, i.e. } \\
\qquad \beta F+\beta L+\beta K=0\end{array}$} \\
\hline & $\beta F+\beta L+\beta K$ & $\mid t$-stat $\mid$ & $\beta F+\beta L+\beta K$ & $\mid t$-stat $\mid$ & No. of obs. \\
\hline$\overline{\mathrm{AUT}}$ & 0.65 & $11.13^{* *}$ & 0.003 & 0.63 & 192 \\
\hline BEL & 0.70 & $8.94^{* *}$ & -0.010 & $2.70^{*}$ & 170 \\
\hline CZE & 0.15 & 1.77 & 0.043 & $3.57^{* *}$ & 136 \\
\hline EST & 0.61 & $3.70^{* *}$ & -0.028 & 1.34 & 44 \\
\hline ESP & 0.47 & $2.90^{* *}$ & -0.002 & 0.35 & 53 \\
\hline FIN & 0.59 & $6.21^{* *}$ & 0.002 & 0.44 & 44 \\
\hline GRC & 0.30 & $3.47^{* *}$ & 0.022 & $2.70^{*}$ & 92 \\
\hline HUN & 0.31 & $3.12^{* *}$ & -0.006 & 0.80 & 71 \\
\hline IRL & 0.48 & $10.24^{* *}$ & -0.004 & 1.45 & 110 \\
\hline LTU & 0.31 & $2.50^{*}$ & -0.039 & 1.63 & 72 \\
\hline LVA & 0.45 & $4.97^{\star *}$ & -0.025 & 1.84 & 166 \\
\hline NLD & 0.64 & $11.43^{* *}$ & 0.001 & 0.17 & 171 \\
\hline POL & 0.53 & $6.67^{\star *}$ & 0.003 & 0.71 & 111 \\
\hline PRT & 0.47 & $6.36^{* *}$ & 0.009 & $2.31^{*}$ & 101 \\
\hline SVN & 0.30 & $4.04^{* *}$ & -0.003 & 0.44 & 124 \\
\hline SVK & 0.32 & $4.38^{* *}$ & 0.005 & 0.67 & 102 \\
\hline
\end{tabular}

Sources: Bankscope; and staff calculations.

Notes: Competitiveness index is calculated from regression results in Table 2. Test for long-run equilibrium estimates the response of pre-tax profits to changes in input prices. A banking sector is in long-run equilibrium if the sum of the response of pre-tax profits to input prices is not significantly different from zero, i.e., $\beta F+\beta L+\beta K=0$. Since profits can be negative, the dependent variable for estimates of the long-run equilibrium is defined as $\ln (1+$ pre-tax profits/total assets). * significant at 5 percent; ** significant at $1 \%$. 


\section{Appendix I. Data Sources and Description of the Sample}

The paper uses Bankscope data, which is a comprehensive database with harmonized, detailed balance sheets and income statements of individual banks in various countries. This database allows for a reasonably consistent cross-country comparison of banking systems. The sample in the study only covers commercial banks, and all values are expressed in U.S. dollars. When available, sample data are based on consolidated statements; otherwise, to maximize sample size, unconsolidated statements are used.

To improve data quality, plausible value ranges are defined for some of the key variables. For example, an observation is excluded from the sample if bank balance sheets for a particular year show a negative value for equity or a value that exceeds 50 percent of banks assets. Similarly, an observation is excluded if average yearly personnel expenses per employee in a bank are below US $\$ 1,000$ or above US $\$ 1$ million. All the imposed rules are defined in Table A1, and this data filter eliminates 10.2 percent of the sample observations.

Table A1. Rules for Data Filtering

\begin{tabular}{lccc}
\hline Variable & Lower Bound & Upper Bound & Fallout (percent) \\
\hline Commisions and fee income/interest income & 0 & 10 & 3.7 \\
Equity/total assets & 0.01 & 0.5 & 3.4 \\
Other administrative and operating expenditures/fixed assets & 0 & 15 & 2.7 \\
Interest income/total earning assets & 0 & 0.25 & 1.1 \\
Interest, commision and fee income/total earning assets & 0 & 0.35 & 0.9 \\
Personnel expenses/employment & 1 & 1000 & 0.2 \\
\hline
\end{tabular}

The remaining dataset covers 16 countries over an eleven-year period from 1995 to 2005. It includes a total of 579 banks. Table A2 lists the number of banks included in the sample for each year and each country. Selected sample statistics for 2005 are summarized in Table A3.

Table A2. Number of Banks Included in the Sample, 1995-2005

\begin{tabular}{lcccccccccccc}
\hline & All years & 1995 & 1996 & 1997 & 1998 & 1999 & 2000 & 2001 & 2002 & 2003 & 2004 & 2005 \\
\hline AUT & 73 & 34 & 35 & 35 & 39 & 38 & 42 & 42 & 44 & 43 & 45 & 43 \\
BEL & 52 & 36 & 39 & 38 & 30 & 29 & 28 & 25 & 29 & 32 & 29 & 23 \\
CZE & 31 & 13 & 16 & 18 & 13 & 17 & 18 & 19 & 18 & 17 & 20 & 17 \\
EST & 11 & 6 & 8 & 9 & 3 & 4 & 5 & 5 & 5 & 5 & 5 & 6 \\
ESP & 93 & 29 & 39 & 37 & 34 & 26 & 27 & 25 & 25 & 18 & 27 & 50 \\
FIN & 10 & 6 & 5 & 6 & 6 & 6 & 4 & 2 & 2 & 2 & 4 & 5 \\
GRC & 27 & 11 & 13 & 13 & 12 & 8 & 7 & 5 & 10 & 12 & 18 & 16 \\
HUN & 28 & 11 & 11 & 15 & 11 & 13 & 17 & 16 & 14 & 15 & 17 & 15 \\
IRL & 34 & 8 & 8 & 9 & 8 & 8 & 8 & 12 & 13 & 14 & 19 & 22 \\
LTU & 13 & 3 & 7 & 10 & 10 & 10 & 10 & 9 & 9 & 9 & 9 & 9 \\
LVA & 29 & 16 & 18 & 21 & 18 & 19 & 19 & 18 & 20 & 22 & 22 & 22 \\
NLD & 52 & 23 & 25 & 21 & 18 & 17 & 14 & 18 & 17 & 18 & 30 & 27 \\
POL & 55 & 19 & 22 & 24 & 27 & 22 & 23 & 17 & 23 & 25 & 33 & 24 \\
PRT & 30 & 18 & 19 & 19 & 19 & 18 & 15 & 12 & 10 & 10 & 13 & 12 \\
SVN & 20 & 11 & 12 & 14 & 15 & 15 & 16 & 15 & 13 & 14 & 15 & 12 \\
SVK & 21 & 8 & 12 & 15 & 12 & 11 & 12 & 13 & 14 & 14 & 14 & 15 \\
Total & 579 & 252 & 289 & 304 & 275 & 261 & 265 & 253 & 266 & 270 & 320 & 318 \\
\hline
\end{tabular}

Source: Bankscope. 
Table A3. Sample Statistics, 2005

\begin{tabular}{|c|c|c|c|c|c|c|c|c|c|c|c|c|c|c|c|c|c|c|}
\hline & \multicolumn{3}{|c|}{$\begin{array}{c}\text { Total assets (bn } \\
\text { USD) }\end{array}$} & \multicolumn{3}{|c|}{$\begin{array}{l}\text { Total earning assets } \\
\text { (bn USD) }\end{array}$} & \multicolumn{3}{|c|}{$\begin{array}{c}\text { Fixed assets (ml } \\
\text { USD) } \\
\end{array}$} & \multicolumn{3}{|c|}{$\begin{array}{c}\text { Deposits, short term } \\
\text { and other funding (bn } \\
\text { USD) }\end{array}$} & \multicolumn{3}{|c|}{ Equity (ml USD) } & \multicolumn{3}{|c|}{ Employment ('000) } \\
\hline & $\begin{array}{l}\text { No. } \\
\text { of } \\
\text { obs. }\end{array}$ & Mean & $\begin{array}{l}\text { St. } \\
\text { Dev. }\end{array}$ & $\begin{array}{l}\text { No. } \\
\text { of } \\
\text { obs. }\end{array}$ & Mean & $\begin{array}{l}\text { St. } \\
\text { Dev. }\end{array}$ & $\begin{array}{l}\text { No. } \\
\text { of } \\
\text { obs. }\end{array}$ & Mean & $\begin{array}{l}\text { St. } \\
\text { Dev. }\end{array}$ & $\begin{array}{l}\text { No. } \\
\text { of } \\
\text { obs. }\end{array}$ & Mean & $\begin{array}{l}\text { St. } \\
\text { Dev. }\end{array}$ & $\begin{array}{l}\text { No. } \\
\text { of } \\
\text { obs. }\end{array}$ & Mean & $\begin{array}{l}\text { St. } \\
\text { Dev. }\end{array}$ & $\begin{array}{l}\text { No. } \\
\text { of } \\
\text { obs. }\end{array}$ & Mean & $\begin{array}{l}\text { St. } \\
\text { Dev. }\end{array}$ \\
\hline$\overline{\text { AUT }}$ & 43 & 8.8 & 30.3 & 43 & 8.3 & 28.2 & 39 & 71.5 & 231.4 & 43 & 7.9 & 27.1 & 43 & 386.9 & $1,359.1$ & 29 & 1.6 & 5.7 \\
\hline BEL & 23 & 66.6 & 165.0 & 23 & 61.2 & 150.0 & 22 & 578.6 & $1,559.8$ & 23 & 58.8 & 146.0 & 23 & $1,967.8$ & $4,500.3$ & 11 & 3.5 & 5.4 \\
\hline CZE & 17 & 3.5 & 4.9 & 17 & 3.3 & 4.6 & 17 & 35.1 & 72.4 & 17 & 3.0 & 4.2 & 17 & 291.6 & 451.1 & 15 & 1.1 & 1.9 \\
\hline EST & 6 & 3.4 & 5.9 & 6 & 3.1 & 5.3 & 6 & 32.5 & 49.9 & 6 & 2.9 & 5.1 & 6 & 293.3 & 507.6 & 5 & 1.9 & 3.0 \\
\hline ESP & 50 & 38.9 & 148.0 & 50 & 35.3 & 131.0 & 49 & 491.2 & $1,826.3$ & 50 & 33.2 & 125.0 & 50 & $2,308.2$ & $8,621.6$ & 17 & 16.0 & 36.8 \\
\hline FIN & 5 & 40.6 & 60.2 & 5 & 37.5 & 58.4 & 5 & 64.7 & 46.4 & 5 & 34.7 & 52.7 & 5 & $3,613.7$ & $6,097.1$ & 5 & 2.9 & 3.7 \\
\hline GRC & 16 & 17.3 & 22.7 & 16 & 15.5 & 20.0 & 16 & 385.0 & 606.5 & 16 & 15.1 & 19.5 & 16 & $1,187.7$ & $1,627.1$ & 11 & 3.0 & 3.6 \\
\hline HUN & 15 & 4.7 & 6.3 & 15 & 4.2 & 5.5 & 15 & 98.9 & 161.9 & 15 & 4.1 & 5.4 & 15 & 410.2 & 648.3 & 11 & 2.6 & 5.3 \\
\hline IRL & 22 & 38.7 & 72.6 & 22 & 37.1 & 70.5 & 19 & 129.6 & 306.4 & 22 & 35.2 & 67.6 & 22 & $1,451.4$ & $2,835.2$ & 21 & 1.1 & 3.6 \\
\hline LTU & 9 & 1.7 & 1.8 & 9 & 1.5 & 1.7 & 9 & 41.3 & 42.2 & 9 & 1.5 & 1.6 & 9 & 130.4 & 145.3 & 7 & 0.9 & 0.8 \\
\hline LVA & 22 & 0.8 & 1.1 & 22 & 0.8 & 1.0 & 22 & 14.0 & 18.7 & 22 & 0.7 & 1.0 & 22 & 65.4 & 83.7 & 21 & 0.5 & 0.7 \\
\hline NLD & 27 & 94.8 & 268.0 & 27 & 88.4 & 254.0 & 26 & 707.3 & $2,348.6$ & 27 & 87.8 & 253.0 & 27 & $2,577.9$ & $6,382.9$ & 22 & 5.6 & 20.5 \\
\hline POL & 24 & 4.7 & 5.6 & 24 & 4.4 & 5.1 & 24 & 78.1 & 113.2 & 24 & 4.1 & 4.8 & 24 & 501.3 & 671.8 & 14 & 3.5 & 4.5 \\
\hline PRT & 12 & 14.6 & 29.0 & 12 & 13.2 & 25.9 & 12 & 129.9 & 296.4 & 12 & 13.0 & 25.9 & 12 & 850.0 & $1,579.0$ & 9 & 3.1 & 6.8 \\
\hline SVN & 12 & 2.9 & 3.8 & 12 & 2.7 & 3.5 & 12 & 59.7 & 93.5 & 12 & 2.6 & 3.5 & 12 & 238.7 & 272.8 & 12 & 1.3 & 2.3 \\
\hline SVK & 15 & 2.2 & 2.6 & 15 & 2.0 & 2.5 & 15 & 44.9 & 60.8 & 15 & 2.0 & 2.3 & 15 & 172.8 & 206.6 & 13 & 1.3 & 1.6 \\
\hline Total & 318 & 21.5 & 51.7 & 318 & 19.9 & 48.0 & 308 & 185.1 & 489.6 & 318 & 19.2 & 46.6 & 318 & 028.0 & $2,249.3$ & 223 & 3.1 & 6.6 \\
\hline
\end{tabular}

Source: Bankscope.

Table A3. Sample Statistics, 2005 (concluded)

\begin{tabular}{|c|c|c|c|c|c|c|c|c|c|c|c|c|c|c|c|c|c|c|}
\hline & \multicolumn{3}{|c|}{$\begin{array}{c}\text { Interest income (ml } \\
\text { USD) }\end{array}$} & \multicolumn{3}{|c|}{$\begin{array}{c}\text { Interest expenses (ml } \\
\text { USD) }\end{array}$} & \multicolumn{3}{|c|}{$\begin{array}{l}\text { Personnel } \\
\text { expenditures (ml } \\
\text { USD) }\end{array}$} & \multicolumn{3}{|c|}{$\begin{array}{l}\text { Other administrative } \\
\text { and operating } \\
\text { expenses (ml USD) }\end{array}$} & \multicolumn{3}{|c|}{$\begin{array}{c}\text { Total operating } \\
\text { expenses (mI USD) }\end{array}$} & \multicolumn{3}{|c|}{$\begin{array}{c}\text { Pre-tax profits (ml } \\
\text { USD) }\end{array}$} \\
\hline & $\begin{array}{c}\text { No. } \\
\text { of } \\
\text { obs. }\end{array}$ & Mean & $\begin{array}{l}\text { St. } \\
\text { Dev. }\end{array}$ & $\begin{array}{l}\text { No. } \\
\text { of } \\
\text { obs. }\end{array}$ & Mean & $\begin{array}{l}\text { St. } \\
\text { Dev. }\end{array}$ & $\begin{array}{l}\text { No. } \\
\text { of } \\
\text { obs. }\end{array}$ & Mean & $\begin{array}{l}\text { St. } \\
\text { Dev. }\end{array}$ & $\begin{array}{c}\text { No. } \\
\text { of } \\
\text { obs. }\end{array}$ & Mean & $\begin{array}{l}\text { St. } \\
\text { Dev. }\end{array}$ & $\begin{array}{c}\text { No. } \\
\text { of } \\
\text { obs. }\end{array}$ & Mean & $\begin{array}{l}\text { St. } \\
\text { Dev. }\end{array}$ & $\begin{array}{l}\text { No. } \\
\text { of } \\
\text { obs. }\end{array}$ & Mean & $\begin{array}{l}\text { St. } \\
\text { Dev. }\end{array}$ \\
\hline$\overline{A U T}$ & 43 & 277.5 & 939.0 & 43 & 172.6 & 30.3 & 43 & 62.7 & 266.9 & 43 & 51.5 & 219.4 & 43 & 140.0 & 598.1 & 43 & 52.9 & 232.8 \\
\hline BEL & 23 & $3,519.4$ & $9,270.8$ & 23 & $2,878.9$ & $8,239.7$ & 23 & 382.8 & 899.2 & 23 & 375.8 & 888.1 & 23 & 763.6 & $1,831.9$ & 23 & 379.5 & 838.1 \\
\hline CZE & 17 & 137.3 & 198.4 & 17 & 61.6 & 65.3 & 17 & 28.6 & 48.1 & 17 & 40.3 & 63.7 & 17 & 72.2 & 118.8 & 17 & 5.9 & 11.8 \\
\hline EST & 6 & 123.5 & 219.7 & 6 & 45.9 & 78.2 & 6 & 32.7 & 56.2 & 6 & 36.3 & 67.3 & 6 & 68.8 & 123.5 & 0 & 65.6 & 120.0 \\
\hline ESP & 50 & $1,527.7$ & $6,099.1$ & 50 & 910.2 & $4,039.7$ & 50 & 310.7 & $1,116.0$ & 50 & 272.1 & $1,051.0$ & 50 & 699.4 & $2,530.4$ & 50 & 460.4 & $1,637.5$ \\
\hline FIN & 5 & $1,070.9$ & $1,461.9$ & 5 & 662.3 & 4.4 & 5 & 190.3 & 226.6 & 5 & 186.4 & 195.0 & 5 & 387.8 & 442.0 & 5 & 317.1 & 42.6 \\
\hline GRC & 16 & 820.8 & $1,088.9$ & 16 & 331.6 & 479.7 & 16 & 233.2 & 294.8 & 16 & 162.0 & 191.1 & 16 & 488.6 & 590.9 & 16 & 220.1 & 353.7 \\
\hline HUN & 15 & 343.0 & 540.3 & 15 & 156.5 & 196.9 & 15 & 70.8 & 112.9 & 15 & 93.7 & 144.4 & 15 & 188.4 & 292.1 & 15 & 107.2 & 225.1 \\
\hline IRL & 22 & $1,282.1$ & $2,543.4$ & 22 & 945.2 & $1,979.9$ & 22 & 163.6 & 430.8 & 22 & 111.6 & 278.7 & 22 & 288.1 & 745.4 & 22 & 259.9 & 580.6 \\
\hline LTU & 9 & 55.3 & & 9 & 19.8 & & 9 & 1 & 16.0 & 9 & .2 & 18 & 9 & .6 & & 9 & & 22.5 \\
\hline LVA & 22 & 31.6 & 43.1 & 22 & 11.5 & 16.6 & 22 & 8.7 & 11.1 & 22 & 11.4 & 14.8 & 22 & 20.8 & 26.1 & 22 & 16.3 & 23.2 \\
\hline NLD & 27 & $3,312.9$ & $9,343.2$ & 27 & $2,335.9$ & $6,492.3$ & 27 & 617.0 & $1,894.2$ & 27 & 526.6 & $1,658.9$ & 27 & $1,186.3$ & $3,691.0$ & 27 & 602.3 & $1,660.9$ \\
\hline POL & 24 & 264.8 & 307.4 & 24 & 121.4 & 127.7 & 24 & 75.3 & 95.8 & 24 & 95.2 & 111.8 & 24 & 178.3 & 220.3 & 24 & 99.5 & 145.6 \\
\hline PRT & 12 & 597.8 & $1,191.0$ & 12 & 342.7 & 666.1 & 12 & 180.6 & 412.1 & 12 & 137.6 & 282.2 & 12 & 364.3 & 763.9 & 12 & 149.7 & 322.8 \\
\hline SVN & 12 & 129.4 & 176.1 & 12 & 56.4 & 73.8 & 12 & 36.5 & 53.4 & 12 & 35.1 & 48.6 & 12 & 89.8 & 124.7 & 12 & 32.2 & 36.7 \\
\hline SVK & 15 & 89.1 & 115.9 & 15 & 31.6 & 36.5 & 15 & 24.0 & 31.5 & 15 & 36.2 & 47.7 & 15 & 64.3 & 84.5 & 15 & 29.3 & 46.9 \\
\hline Total & 318 & 848.9 & $2,099.8$ & 318 & 567.8 & $1,495.4$ & 318 & 152.1 & 372.9 & 318 & 136.9 & 330.1 & 318 & 315.0 & 764.0 & 318 & 179.1 & 425.0 \\
\hline
\end{tabular}

Source: Bankscope. 


\section{References}

Bank of Slovenia, 2006, Financial Stability Report, (Ljubljana: Bank of Slovenia).

Berger, A., and others, 2004, "Bank Concentration and Competition: An Evolution in the Making," Journal of Money, Credit and Banking, Vol. 36, (June), pp. 433-51.

Bikker, J., and K. Haaf, 2002, "Competition, Concentration and Their Relationship: An empirical Analysis of the Banking Industry," Journal of Banking and Finance, Vol. 26, pp. 2191-214.

Bikker, J., L. Spierdijk, and P. Finnie, 2006, "Misspecification of the Panzar-Rosse Model: Assessing Competition in the Banking Industry," mimeo, De Nederlandsche Bank, November.

Claessens, S., and L. Laeven, 2004, "What Drives Bank Competition? Some International Evidence,” Journal of Money, Credit and Banking, Vol. 36, (June), pp. 563-92.

ECB, 2006, EU Banking Structures, (Frankfurt: ECB).

Gelos, G., and J. Roldos, 2002, “Consolidation and Market Structure in Emerging Market Banking Systems,” IMF Working Paper 02/186 (Washington: IMF).

Giannetti, M., and others, 2002, "Financial Market Integration, Corporate Financing and Economic Growth,” European Economy Economic Papers, No. 179 (Brussels: EC, Directorate General for Economic and Financial Affairs).

Kumbhakar, S., and K. Lovell, 2000, Stochastic Frontier Analysis, (Cambridge: Cambridge University Press).

Micco, A., U. Panizza, and M. Yanez, 2004, “Bank Ownership and Performance,” IADB Working Paper No. 518 (Washington: Inter-American Development Bank).

Panzar, J., and J. Rosse, 1987, “Testing for 'Monopoly' Equilibrium,” Journal of Industrial Economics, Vol. 35, (June), pp 443-56. 


\section{BANK RISKS FROM CROSS-BORDER LENDING AND BORROWING IN SLOVENIA ${ }^{15}$}

- Summary
- $\begin{aligned} & \text { Slovene banks are increasingly relying on foreign funding to finance credit, mostly on } \\ & \text { loans from EU banks. At the same time, to boost profits, banks are increasing their } \\ & \text { exposure into regions with wider margins, such as the rest of former Yugoslavia. }\end{aligned}$
The expansion of cross-border lending and borrowing can make Slovene banks more
vulnerable to interest rate and funding risks, while lending in riskier countries can raise
credit and currency risks.
Stress tests do not point to high vulnerabilities, given the still small share of foreign
assets, but information on foreign credit exposure could be improved. Future
developments should be closely monitored, and stress tests should include more
disruptive scenarios of combined shocks.

\section{A. Introduction}

34. Slovene banks have increased cross-border borrowing and lending to compensate for pressures on profitability at home. Profitability has been under pressure since EU integration and euro adoption, as greater competition is narrowing interest margins and revenues from foreign exchange transactions are being reduced. To increase revenues, Slovene banks have started to expand cross-border lending and capital investments in highmargin regions, such as Southeastern Europe. At the same time, to finance growing demand for credit, while depositors are shifting to higher yielding mutual funds, Slovene banks have resorted to foreign borrowing.

35. These trends can increase vulnerability to various risks. The foreign operations expose Slovene banks to risks related to changes interest rates, direct or indirect currency and credit risks from exposure in riskier markets. The dependency on foreign loans could also increase funding risks, if foreign banks suddenly reduce lending in response to a common shock to the region.

36. The paper assesses the nature of these vulnerabilities using stress tests. After a brief description of the extend of Slovene banks' cross-border transactions, the paper, based on stress tests conducted by the Bank of Slovenia, analyzes banks' exposure to interest rate, credit, currency, and liquidity risk. It concludes with some policy observations.

\footnotetext{
${ }^{15}$ Prepared by Jochen Andritzky (MCM) in collaboration with Tomaz Kosak, Financial Stability Department, Bank of Slovenia.
} 
37. The paper finds that vulnerabilities are contained mainly due to the still modest foreign exposure in total assets. The analysis shows that moderate interest rate and margin shocks are not found to put unsustainable pressure on the banking system, as foreign borrowing has reduced the maturity mismatch and lowered the interest rate sensitivity. While the introduction of the euro has lowered currency risks, increasing exposure to foreign credit risk raises vulnerabilities with regard to a downturn in Southeastern Europe (SEE). While these risks warrant greater vigilance, especially as they are concentrated in a few banks, the current size of foreign lending relative to total assets is still small. Liquidity risks, for example, from the withdrawal of foreign funding, are limited for domestic-owned banks, while foreign-owned banks are heavily dependent on financing from their mother institution.

\section{B. Extent of Cross-Border Lending and Borrowing}

\section{The increase in cross-border assets has been concentrated in a few Slovene}

banks. While part of this reflects a rise in holdings of European securities after Slovenia's entry into the EU in 2004, loans to non-residents increased from 6 percent in 2004 to about 8 percent of banks' balance sheets in 2006. The strongest growth took place in the rest of former Yugoslavia, which reached 3.3 percent of banks' balance sheets in 2006, and was driven by the largest bank in Slovenia. These exposures include loans, off-balance sheet liabilities and securities. While the exposure to nonresidents is dominated by lending to foreign banks, claims to the foreign nonbanking sector are also increasing. The largest bank has also raised its foreign assets via acquisitions, which will add to the risks from cross-border activities (Box 1). However, this study only covers direct loan growth abroad in the assessment of vulnerabilities.

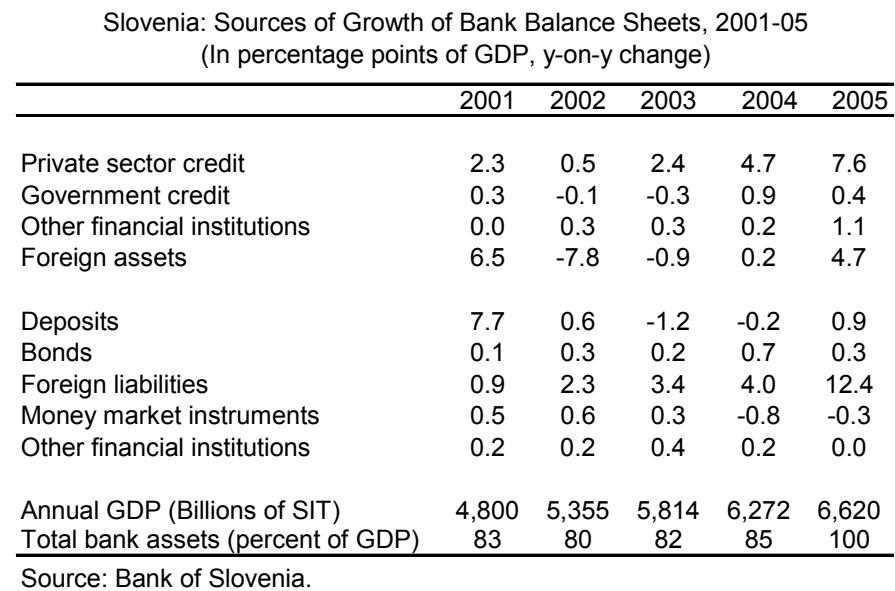

39. Most banks have increased borrowing from foreign sources. Foreign loan exposure of Slovenian banks grew from 2 to 12 percent of GDP between 2002-05. The annual growth of over 50 percent in recent years has been higher than the average for other new EU members. This helped finance domestic credit growth at around 20 percent annually. Liabilities to foreign banks now account for 30 percent of total liabilities, and are highest in the foreign owned banks. 
Net Interest Margin (percent)

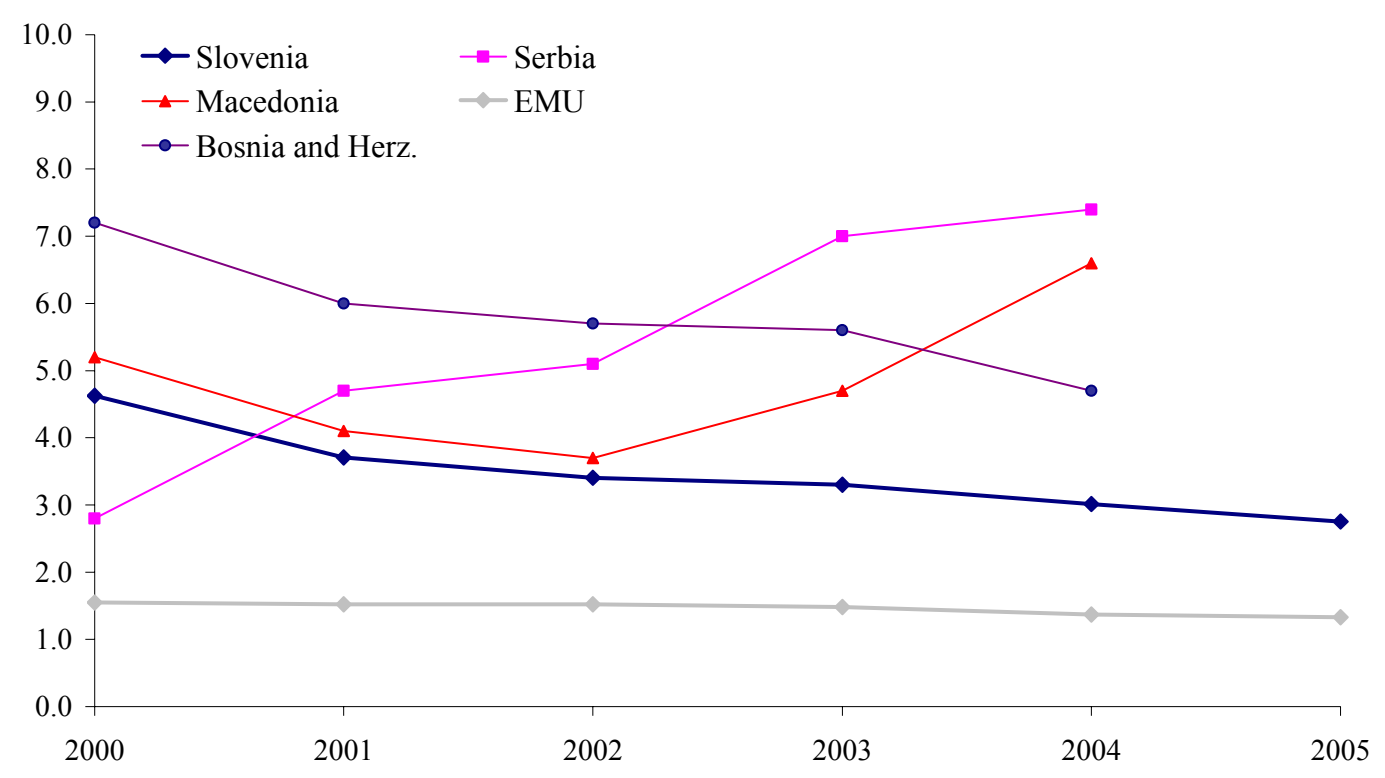

Sources: Bankscope; and staff estimates.

40. The main forces driving Slovene banks' foreign activities are wider margins and lower cost of funds. Margins in Slovenia are gradually converging to euro area levels. In 2006, the net interest margins in domestic banks were 2.3 percentage points compared to 1.8 in foreign-owned ones. The other SEE countries, however, offer significantly higher, albeit volatile margins that can go up to 7 percentage points. Expansion to these higher margins markets has helped Slovene banks sustain profits, that have been under pressure in recent years. Reliance on foreign credit, in turn has been less costly that increasing domestic deposit rates, that compete with returns to mutual funds.

Slovenıa: Bankıng Sector Soundness Indicators, 2U03-US

(In percent; end of period)

\begin{tabular}{lccc}
\hline & 2003 & 2004 & 2005 \\
\hline Regulatory capital to risk-weighted assets & 11.5 & 11.8 & 10.6 \\
Net interest margin to average interest bearing assets & 3.2 & 2.8 & 2.5 \\
Return on average assets (before tax) & 1.0 & 1.1 & 1.0 \\
Average short-term assets to average short-term liabilities & 93.2 & 88.4 & 84.8 \\
Variable rate contracts (share of new loans of largest 8 banks) & 30.1 & 38.5 & 54.5 \\
\hline
\end{tabular}

Source: Bank of Slovenia. 


\section{Box 1. Foreign Expansion of Nova Ljubljanska Banka (NLB)}

The foreign expansion of the banking system is led by NLB, the largest Slovene banking group. NLB accounts for 40 percent of total Slovene banking sector assets, and is majority owned directly and indirectly by the state. Two stylized facts on its foreign expansion stand out--foreign asset exposure through subsidiaries in South-Eastern Europe and Switzerland more than doubled over 2000-05, and it earns a disproportionate share of income and profits from its foreign expansion. For example, assets in Macedonia, Serbia, Bosnia and Herzegovina, and Switzerland grew from 3 percent in 2000 to 8 percent of total in 2005. Over the same period, as a proportion of group profits, contribution of the four countries grew from 1 percent to 19 percent. A similar story emerges for operating income and net interest revenue.

Assets (\% of total consolidated group)

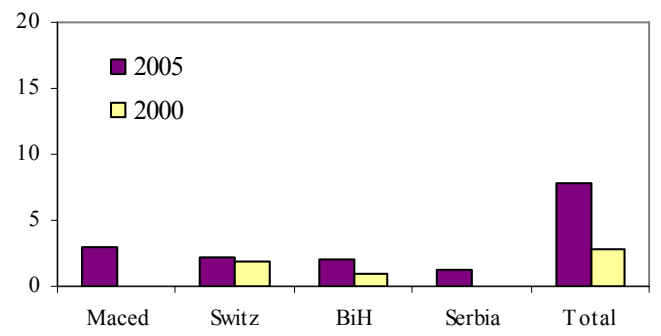

Total Operating Income (\% of total consolidated group)

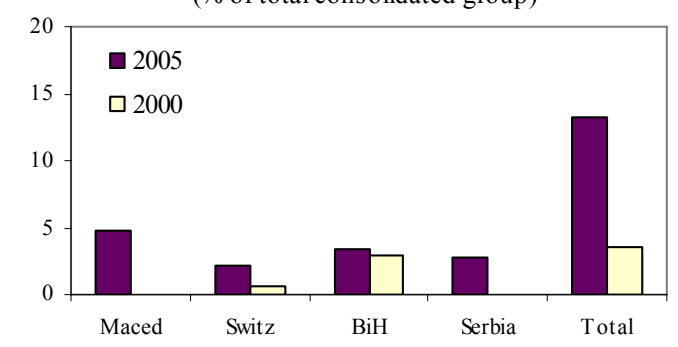

Net Interest Revenue (\% of total consolidated group)

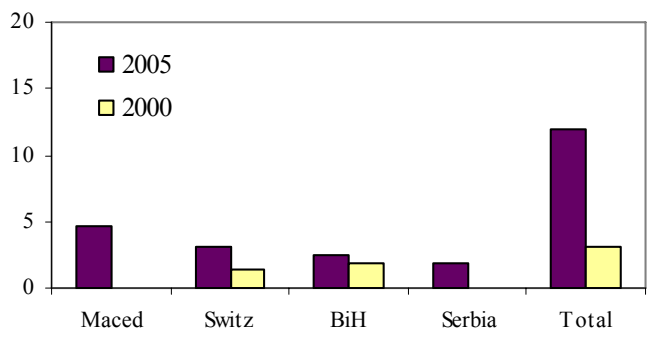

Pre-Tax Profit

(\% of total consolidated group)

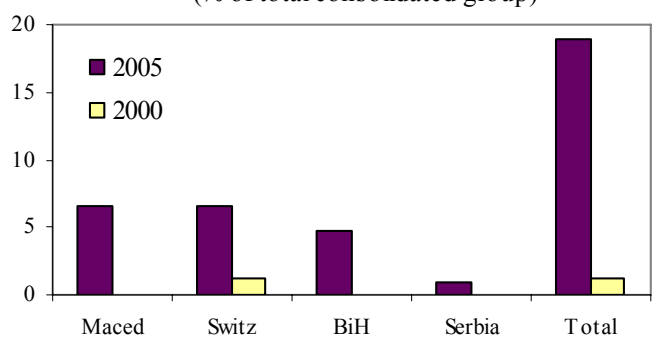

Source: Bankscope, staff calculations

\section{Stress Tests with Risks from Cross-Border Finance}

41. The vulnerabilities related to foreign expansion are assessed using stress tests on shocks to interest rate, credit, currency and liquidity risks. The tests are based on model results provided by Bank of Slovenia (BoS). In some cases, given the differences in foreign activities of Slovene banks, they are divided into three groups in these tests: large domestic (six), small domestic (seven) and foreign owned banks (nine with foreign controlling stakes). Details on the methodology and assumptions are in the Annex. 


\section{Interest rate risk}

\section{Foreign lending and borrowing affect interest rate risk through interest margins}

and maturities. Interest income can be affected by divergences in foreign lending and borrowing rates. By relying on cheap funding from the euro area and investing in high margin areas, such as SEE, Slovene banks become subject to increased earnings risk from shifts in interest rates. Foreign lending and borrowing can also change the maturity composition on the banks' balance sheets with different sensitivities to interest rate changes.

\section{Slovene banks are resistant to temporary modest interest rate shocks. A two} standard deviation shock to interest rates (2.4 percentage points) shows that the effective interest rate (that takes account of rigidities in balance sheets) would rise by less than 2 percentage points. As a result, interest revenue and expenses are higher in 2006 and 2007 compared to the baseline scenario, but net interest revenue falls This drop is partly offset by lower costs, such as lower provisions, reducing the negative impact on profits. ${ }^{16}$ Capital adequacy is affected more by reduced loan growth than by lower profits, which improves the capital adequacy ratio (CAR) at the time of the shock. Thus the test shows that changes on the banks' balance sheets in response to changes in interest rates remain moderate with significant growth of loans prevailing. However, the interest rate shock used by the test may be too small biasing the results. For example, stress tests conducted by the IMF in the Financial Sector Assessment Program usually apply a shock of three standard deviations to interest rates, and the Basel Committee Amendment to the Capital Accord suggests interest rate increases between 100 and 300 basis points with stress tests.

\begin{tabular}{|c|c|c|c|c|c|c|c|c|}
\hline \multicolumn{9}{|c|}{ Implications of the Interest Rate Shock } \\
\hline & $\begin{array}{c}\text { Profit } \\
\text { in Euro } \mathrm{mln}\end{array}$ & $\begin{array}{c}\text { Return } \\
\text { on Equity }\end{array}$ & $\begin{array}{c}\text { Capital } \\
\text { Adequacy }\end{array}$ & $\begin{array}{c}\text { Growth of loans } \\
\text { to non-banks }\end{array}$ & $\begin{array}{l}\text { Non-bank } \\
\text { loans / TA }\end{array}$ & $\begin{array}{c}\text { Growth of deposits } \\
\text { by non-banks }\end{array}$ & $\begin{array}{c}\text { Non-bank } \\
\text { deposits / TA }\end{array}$ & $\begin{array}{c}\text { Growth of } \\
\text { TA }\end{array}$ \\
\hline & \multicolumn{8}{|c|}{ Baseline scenario } \\
\hline 2006 & 346.4 & 13.3 & 11.2 & 26.0 & 57.4 & 8.8 & 53.0 & 19.9 \\
\hline 2007 & 399.8 & 13.7 & 11.0 & 22.5 & 61.7 & 8.2 & 50.3 & 13.8 \\
\hline 2008 & 416.5 & 12.6 & 10.0 & 22.5 & 65.3 & 7.4 & 46.7 & 15.7 \\
\hline \multicolumn{9}{|c|}{ Raising interest rates in the period from Q4 2006 to Q3 2007} \\
\hline 2006 & 318.4 & 12.2 & 11.3 & 25.6 & 57.3 & 8.9 & 53.1 & 19.7 \\
\hline 2007 & 251.6 & 8.6 & 11.1 & 18.5 & 60.9 & 8.5 & 51.6 & 11.6 \\
\hline 2008 & 419.8 & 12.7 & 9.9 & 26.0 & 65.2 & 7.7 & 47.2 & 17.7 \\
\hline \multicolumn{9}{|c|}{ Differences from the baseline scenario } \\
\hline 2006 & -28.0 & -1.1 & 0.0 & -0.4 & -0.1 & 0.0 & 0.1 & -0.2 \\
\hline 2007 & -148.1 & -5.1 & 0.2 & -4.0 & -0.9 & 0.3 & 1.3 & -2.3 \\
\hline 2008 & 3.3 & 0.1 & -0.1 & 3.6 & -0.2 & 0.3 & 0.5 & 2.0 \\
\hline
\end{tabular}

Source: Bank of Slovenia.

44. Foreign borrowing by banks has reduced exposure to interest rate sensitivity by lengthening maturities and reducing maturity mismatch. While about two-thirds of domestic deposits mature within one year, only 12 percent of the banks' foreign loans are short-term. This has improved the maturity structure of banks reducing interest rate and rollover risks. Time to repricing (the remaining time until a change in benchmark rates takes

\footnotetext{
${ }^{16}$ The adoption of the International Financial Reporting Standards (FRS) in 2006 is expected to support growth in profits in the medium term.
} 
effect) also shows that 94 percent of domestic deposits are repriced within one year, while at 88 percent for foreign credit the share is slightly lower. The average time to repricing of foreign assets also fell from 19 to 16 months between 2005-06, while it remained broadly stable at 6 months for foreign liabilities. As a result, foreign funding has reduced the maturity mismatch for Slovene banks, reducing sensitivity to interest rate shocks.

\section{Banks can sustain moderate increases in foreign funding costs through smaller} profits. A 0.5 percentage point reduction of the net interest rate margin, which corresponds to a rise in foreign funding costs by about 2 percentage points, is absorbed by banks through lower profits. The shock would leave the CAR broadly unaffected as there are no balance sheet effects assumed. However, the test may be too mild as it would leave the net interest rate margin at a level above the current EU average. An earlier IMF assessment applied a more significant shock that halved the interest margins. As a result, banks would have incurred losses, and three banks would have required a capital injection. ${ }^{17}$

Impact of the Margin Shock

\begin{tabular}{cccc}
\hline & Profit (EUR mln) & Return on Equity & Capital Adequacy \\
\hline & & Baseline scenario & \\
2006 & 346.4 & 13.3 & 11.2 \\
2007 & 399.8 & 13.7 & 11.0 \\
2008 & 416.5 & 12.6 & 10.0 \\
\hline & Fall in the interest margin by 0.5 percentage points in the period from Q4 2006 to Q3 2007 \\
2006 & 308.0 & 11.8 & 11.2 \\
2007 & 274.6 & 9.4 & 10.8 \\
2008 & 416.5 & 12.6 & 9.8 \\
\hline & & & \\
2006 & -38.0 & Differences from the baseline scenario & 0.0 \\
2007 & -124.8 & -1.5 & -0.2 \\
2008 & 0.0 & -4.3 & -0.2 \\
\hline
\end{tabular}

Source: Bank of Slovenia.

46. In sum, the stress test show that the Slovene banking system can easily absorb moderate interest rate and margin shocks. A sensitivity analysis for a temporary interest rate shock results in lower profits, but credit growth and capital adequacy are sustained. Foreign borrowing has increased the duration of the banks' liabilities, therefore reducing the maturity mismatch. A jump in foreign funding costs, that reduces the net interest margin, could significantly reduce profits, but only a very dramatic fall in margins would result in losses and undercapitalization. However, the shocks are relatively mild, and larger shocks, or the combination of shocks such as a deterioration in credit quality, credit losses or a sudden stop of foreign funding can show greater vulnerabilities. This, however, remains to be tested.

\footnotetext{
${ }^{17}$ See IMF (2004), p. 14.
} 


\section{Credit and currency risk}

Balance Sheet and Off-Balance-Sheet Assets of Banks and Special Provisions (September 2006)

\begin{tabular}{lcccc}
\hline & Loans to & \multicolumn{3}{c}{ Loans to Nonbanks } \\
\cline { 3 - 5 } & Banks & EU & Non-EU & Ex-Yugo \\
\hline Foreign claims (percent of total assets) & 18.4 & 7.6 & 5.2 & 2.2 \\
Foreign classified assets (percent of total assets) & 14.4 & 3.0 & 3.6 & 2.1 \\
Provisions (percent of foreign classified assets) & 0.5 & 10.5 & 5.5 & 5.5 \\
\hline
\end{tabular}

Sources: Bank of Slovenia; and staff calculations.

47. Credit and currency risks arise mainly from exposures to SEE. Euro adoption and EU membership are likely to have reduced some of these risks for Slovenia, while growing exposure to SEE raises mainly credit and currency risks in a region that still needs to see a slow-down in growth.

48. The greater credit risks of foreign lending are reflected in higher provisions in Slovene banks, which should mitigate vulnerabilities. Non-resident loans are classified riskier than domestic loans by banks--provisions for loans to non-residents are about 9 percent compared to about 4 percent for all loans. This reflects the higher proportion of nonperforming loans (NPL) in some areas, such as SEE, where estimates of the NPL ratio range from 3 to 10 percent.

49. However, banks' ability to face risks is reduced by low provisions for loans to subsidiaries of Slovene banks and to Slovene enterprises in SEE. Foreign subsidiaries originate loans in their credit portfolios and refinance them through their mother institution in Slovenia. However, the latter classify these loans as low risk. ${ }^{18}$ This may also explain why provisioning in Slovenia to non-EU countries is lower than to EU-countries. As data on onlending by these foreign subsidiaries is not available, and thus credit risk at the subsidiaries and the likelihood of a risk pass-through are hard to quantify. This can mean that credit risks abroad may be underestimated in balance sheets in Slovenia.

50. At the same time, currency risks in Slovene banks from foreign operations have been substantially reduced by euro adoption. On the funding side, euro adoption eliminated much of the currency risk, while on the lending side, indirect currency risks remain despite the fact that loans in SEE tend to be in foreign currencies. ${ }^{19}$ While the euro is the most common currency of denomination in these countries, some loans, in particular residential housing loans, are denominated in non-euro currencies, such as Swiss francs. Part

\footnotetext{
${ }^{18}$ Loans to subsidiaries are classified as A-rated on a rating scale from A to E.

1978 percent of lending in Croatia, and 85 percent in Serbia, (in particular so for long-term lending) is denominated in non-domestic currency.
} 
of the lending may also be to unhedged borrowers, that may be vulnerable to a sudden change in market conditions or exchange rates. This in a way can substitute currency risk for credit risk in exposure to SEE. As the lending business expands rapidly during times of benign economic circumstances, the quality of this segment of lending, and the appropriate handling of a downturn, is yet to be tested

\section{Overall, currency and credit risks from foreign operations of Slovene banks} remain small given the still limited exposure in total assets. Despite rapid growth in lending to SEE, and potential under-provisioning for credit risks in the region, this exposure at 3 percent of the banks' balance sheets remain small. Together with euro adoption, this suggests that overall risks from exposure to SEE are low. However, their development should be monitored closely. Loan growth to this region is high, and available information on the pass-through of credit risk from foreign lending appears limited despite well established supervisory cooperation.

\section{Liquidity risk}

52. The growing dependence of Slovenia's bank finance on external funds increases the sector's vulnerability to liquidity risk. Given the banks' funding from the euro-area and their credit exposure to SEE, a sudden downturn in the latter region could have repercussions on Slovene banks. A contagion scenario, triggered for example, by a shock in some of the SEE countries, would not only deteriorate the credit quality of Slovene bank assets, but could at the same time cause a sudden stop of foreign funding. To assess these risks, the following traces the origins of capital flows to Slovenia and evaluates a potential impact of a withdrawal of foreign lending on the banks' liquidity ratio and profitability.

\section{The vulnerability to contagion in Slovenia and in SEE is increased by} concentration of foreign funding to banks in a few neighboring EU countries. Austria is the most dominant provider of capital to Slovenia, as to SEE in general, followed by Germany. Most of the investments are bank loans reflecting the relatively underdeveloped financial markets. The dominance of a few countries in the bank loans may reflect the distribution of foreign equity participations in Slovenia--most of the 35 percent of foreign held-equity originates in Austria and Germany. As the same banks are active in other countries in the region as well, potential for contagion risks is increased. By the end of 2005, half of all Eastern European foreign owned bank assets were concentrated in eight bank groups. 
Figure 1. Foreign Bank and Portfolio Investment by Residence of Investor, 2005 (In billions of U.S. dollars)

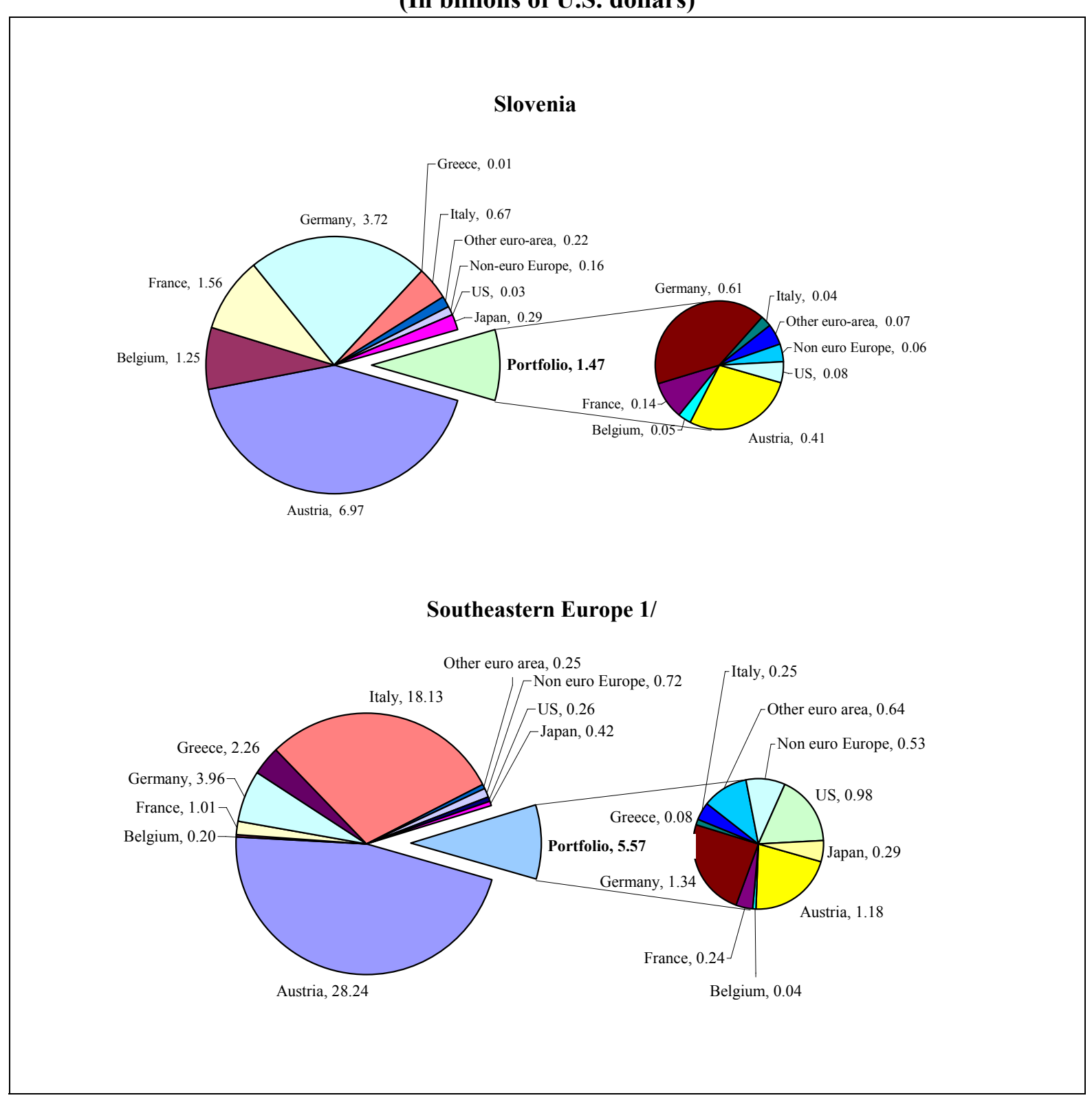

Sources: BIS; CPIS; and staff estimates.

1/ Albania, Bosnia and Herzegovina, Croatia, Macedonia, Serbia and Montenegro. Other euro-area includes Netherlands, Portugal, Spain; Non-euro Europe includes Denmark, Norway, Sweden, Switzerland, United Kingdom. Data unavailable or confidential for bank loans from Norway and portfolio investments from United Kingdom. 
Eastern European Bank Asset Structure, by Key Bank Groups, end-2005 1/

(In percent of total CEE banking sector assets)

Source: RZB Group (2006).

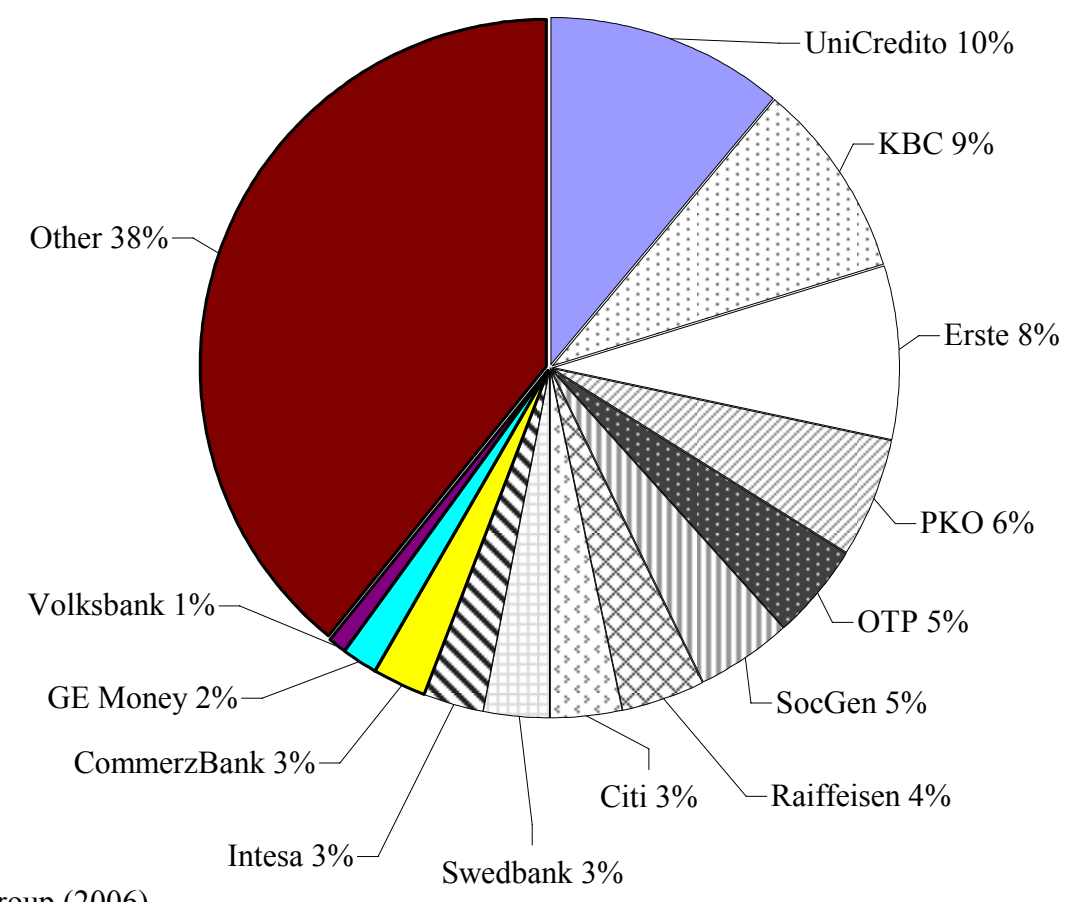

1/ Markets include Albania, Belarus, Bosnia and Herzegovina, Bulgaria, Croatia, Czech Republic, Estonia, Hungary, Kosovo, Latvia, Lithuania, Poland, Romania, Russia, Serbia (data presented are for Serbia and Montenegro), Slovakia, Slovenia, and Ukraine.

\section{The vulnerability of Slovene banks to sudden stops was tested with changes to}

the liquidity ratio. This stress test assesses the change in the liquidity ratio (which is defined as the ratio between liquid assets and short-term liabilities) and pre-tax profits in two scenarios--a withdrawal of liabilities to foreign banks by 20 and 100 percent. The reduction in liabilities to foreign banks is followed by an adjustment on the asset side according to their degree of liquidity. Depending on the liquidity need and the available liquid assets, the stress test shows whether banks need to diminish their credit activity. However, this test can slightly underestimate the impact of sudden stops, as this may also have repercussions on the whole economy. 


\begin{tabular}{|c|c|c|c|c|c|c|c|c|c|c|c|c|c|}
\hline \multirow[b]{4}{*}{ (In Euro bln) } & \multicolumn{13}{|c|}{ Liquidity Stress Test: Balance Sheet Items (actual and scenario) } \\
\hline & \multicolumn{5}{|c|}{ Actual } & \multicolumn{4}{|c|}{ Foreign liquidity shock of $20 \%$} & \multicolumn{4}{|c|}{ Foreign liquidity shock of $100 \%$} \\
\hline & \multirow{2}{*}{$\begin{array}{l}\text { Total } \\
\text { Dec-05 }\end{array}$} & \multirow{2}{*}{$\begin{array}{c}\text { Total } \\
\text { (Sep 2006) } \\
\end{array}$} & \multicolumn{2}{|c|}{ Domestic Banks } & \multirow{2}{*}{$\begin{array}{c}\begin{array}{c}\text { Foreign } \\
\text { Banks }\end{array} \\
\end{array}$} & \multirow[t]{2}{*}{ Total } & \multicolumn{2}{|c|}{ Domestic Banks } & \multirow{2}{*}{$\begin{array}{c}\text { Foreign } \\
\text { Banks }\end{array}$} & \multirow[t]{2}{*}{ Total } & \multicolumn{2}{|c|}{ Domestic Banks } & \multirow{2}{*}{$\begin{array}{c}\begin{array}{c}\text { Foreign } \\
\text { Banks }\end{array} \\
\end{array}$} \\
\hline & & & Large & Small & & & Large & Small & & & Large & Small & \\
\hline Total assets & 36.4 & 32.4 & 21.5 & 3.4 & 7.5 & 30.6 & 20.5 & 3.4 & 6.7 & 23.3 & 16.6 & 3.3 & 3.4 \\
\hline Interbank assets & 3.6 & 3.2 & 2.1 & 0.4 & 0.8 & 1.6 & 1.1 & 0.3 & 0.2 & 0.3 & - & 0.2 & 0.0 \\
\hline Cash reserve & 0.6 & 0.5 & 0.4 & 0.1 & 0.1 & 0.5 & 0.4 & 0.1 & 0.1 & 0.1 & - & 0.1 & - \\
\hline $\mathrm{DIC}$ & 6.9 & 5.1 & 3.5 & 0.6 & 0.9 & 5.0 & 3.5 & 0.6 & 0.8 & 1.8 & 1.2 & 0.6 & - \\
\hline Securities held for trading & 2.0 & 1.4 & 1.0 & 0.2 & 0.2 & 1.4 & 1.0 & 0.2 & 0.2 & 1.1 & 0.9 & 0.2 & - \\
\hline Short-term NBS assets & 6.5 & 6.4 & 4.3 & 0.9 & 1.2 & 6.4 & 4.3 & 0.9 & 1.2 & 5.6 & 4.3 & 0.9 & 0.4 \\
\hline Other assets & 16.7 & 15.8 & 10.2 & 1.3 & 4.3 & 15.8 & 10.2 & 1.3 & 4.3 & 14.5 & 10.2 & 1.3 & 3.0 \\
\hline \multicolumn{14}{|l|}{ Liabilities } \\
\hline Liabilities to foreign banks & 9.8 & 9.2 & 4.9 & 0.2 & 4.1 & 7.3 & 3.9 & 0.1 & 3.3 & - & - & - & - \\
\hline Liabilities to domestic ban & 0.6 & 0.7 & 0.3 & 0.3 & 0.1 & 0.7 & 0.3 & 0.3 & 0.1 & 0.7 & 0.3 & 0.3 & 0.1 \\
\hline ST Liabilities to NBS & 9.5 & 8.2 & 5.8 & 1.1 & 1.3 & 8.2 & 5.8 & 1.1 & 1.3 & 8.2 & 5.8 & 1.1 & 1.3 \\
\hline Other liabilities & 16.4 & 14.4 & 10.5 & 1.9 & 2.0 & 14.4 & 10.5 & 1.9 & 2.0 & 14.4 & 10.5 & 1.9 & 2.0 \\
\hline Liabilities to foreign banks & 0.3 & 0.3 & 0.2 & 0.1 & 0.5 & 0.2 & 0.2 & 0.0 & 0.5 & - & - & - & - \\
\hline Liquidity ratio & 0.99 & 0.92 & 1.03 & 1.37 & 0.58 & 0.92 & 1.03 & 1.37 & 0.51 & 0.92 & 1.05 & 1.41 & 0.26 \\
\hline
\end{tabular}

Source: Bank of Slovenia.

55. Foreign-owned banks are most vulnerable to a withdrawal of foreign funding. About one half of total assets and liabilities in the Slovene banking system are short-term. The share of short-term liabilities provided from abroad is 40 percent for domestic banks, and three quarters for foreign-owned banks. As a result, smaller banks have the most comfortable liquidity ratio, while it is lowest in the foreign-owned banks. This may reflect the foreign-owned banks' role of transferring funds from their parent banks to long-term loans in Slovenia. The stress test, that assumes that short-term assets can be liquidated without any problems, shows that domestic banks can sustain the complete withdrawal of foreign funding without incurring liquidity problems. In contrast, foreign owned banks, that depend on foreign funding, are more vulnerable. In case of a complete withdrawal, foreign banks would suffer from an insufficient liquidity ratio, and would need to liquidate their long-term assets. However, the stress-test scenario assumes that foreign subsidiaries are abandoned by their mother institutions, which is unlikely.

Impact of a Liquidity Shock on Profits

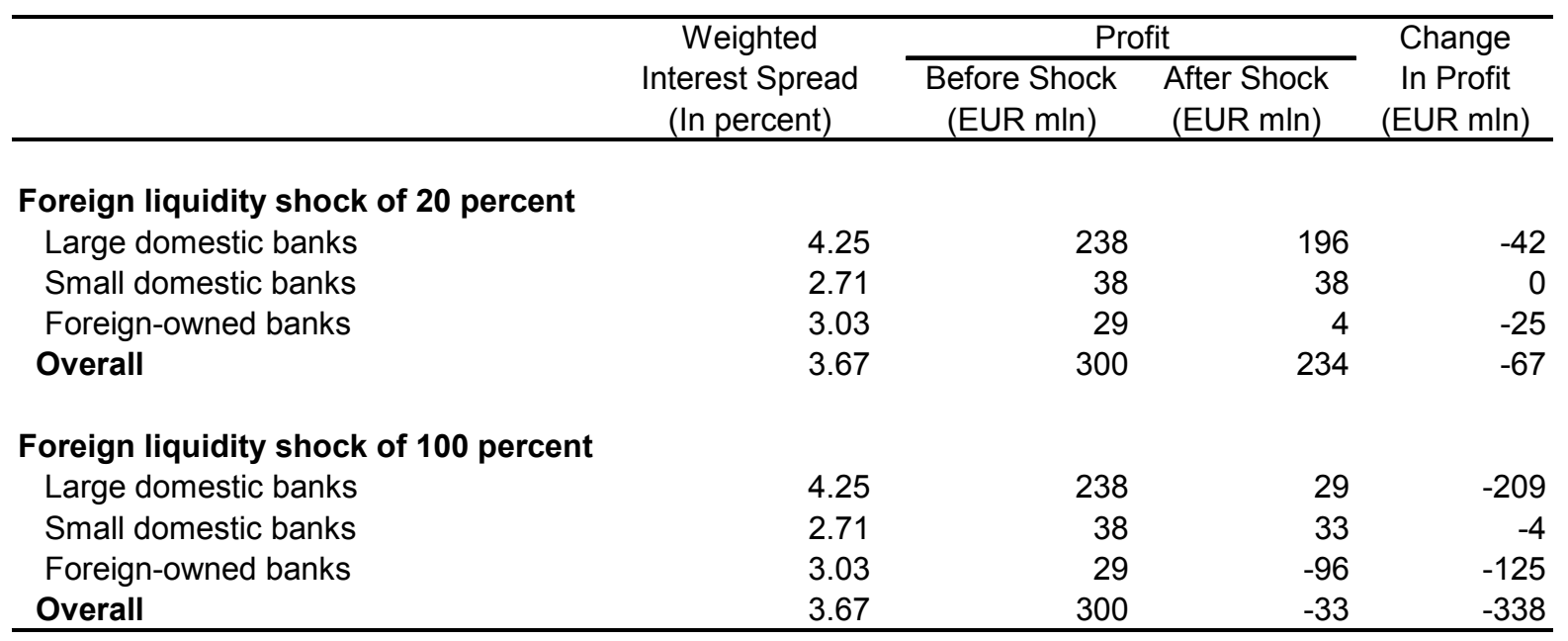

Source: Bank of Slovenia. 
56. Foreign banks are most vulnerable to sudden stops, with the larger shock causing a profound loss of income. With 20 percent withdrawal of liabilities to foreign banks, six of the nine foreign-owned banks would make losses. In case of a complete withdrawal, all foreign owned banks and two large domestic banks would incur losses.

57. If feedback effects are incorporated, a liquidity shock would also impair large domestic banks. The current test assumes that banks can choose liquidating interbank loans, while the effect on the counterparty's balance sheet is not taken into account. In case of a full withdrawal of foreign funding, the complete liquidation of all interbank assets (as suggested in the table) might prove unrealistic as this would send shock waves throughout the banking system. Taking feedback effects of liquidating all interbank loans into account, large domestic banks would be left with insufficient liquidity ratios.

58. In sum, the analysis shows that liquidity risk in Slovenia is low. Although the tests point to some vulnerability to sudden stop shocks, their occurrence in Slovenia is likely to be small. While a shock in SEE may cause foreign banks to reduce exposure in the region, they are likely to differentiate with Slovenia given its membership in the euro area and the EU. Its exposure in SEE is also still modest to create major concerns for the banking system in Slovenia. However, this is not to say that Slovenia would not be impacted by a slow-down in foreign credit given its high reliance on foreign borrowing from a few sources to finance asset growth. Thus diversification of the funding base would spread the risks better and reduce the vulnerability to liquidity risk.

\section{Conclusions}

59. While vulnerabilities to various risks from foreign exposure seem contained in Slovenia, the rise in cross-border activities merits close monitoring. While increasing the dependence on foreign funds, borrowing from abroad has diversified the funding base and contributed to a lower maturity mismatch reducing exposure to interest rate risks. The strong expansion of lending abroad has mitigated the margin pressure on Slovene banks, but it comes at the expense of higher credit risks. Although this exposure remains small in total, the current provisions may not fully cover these risks. A deterioration of foreign credit quality, possibly upon the end of the current credit boom in SEE, could cut into profits. Despite a concentration of funding from a few sources in Europe exposed to elsewhere in Eastern Europe, and large impact of sudden stops with stress tests, contagion risks remain small given Slovenia's euro area membership.

60. Closer monitoring, in particular with regard to credit risks, and broader stress tests could add to the understanding of risks from cross-border lending and borrowing. The analysis on credit risk is limited by data availabilities, and, more generally by perhaps benign assumptions. Better reporting of credit risks in SEE would give more information on country exposure and currency composition from foreign lending and borrowing. More thorough information about the credit quality of non-resident loans and the loan portfolios of 
Slovene banks' foreign subsidiaries are also necessary to monitor the appropriateness of provisions. ${ }^{20}$ Stress tests could be extended to analyze a scenario which combines a sudden decline in foreign funds with a simultaneous deterioration of credit quality of foreign loans, including those to foreign subsidiaries of Slovene banks.

\section{Cross-border supervisory cooperation will also remain important in detecting}

vulnerabilities. Supervisory coordination between EU countries could serve as benchmark to establish a level playing field of foreign banks active in non-EU countries. ${ }^{21}$ Besides crossborder interagency communication, memoranda of understanding could also encompass crisis prevention. ${ }^{22}$

\footnotetext{
${ }^{20}$ The 2004 FSAP recommendations have already pointed out that the banking supervision should strengthen its risk focus and ensure that pricing of risk and provisioning are appropriate. Furthermore, supervisors should give consideration to how prudential tools, including provisioning policies, could be used to address risks.

${ }^{21}$ See Belaisch and others (2001).

${ }^{22}$ See IMF (2007).
} 


\section{Appendix I. Assumptions of the Stress Test}

\section{Interest rate stress test}

The interest rate shock used--a temporary interest rate increase of 2.4 percentage points--corresponds to two standard deviations of the variance in the last 11.5 years. This scenario assumes that the two main reference interest rates, the yield on 60-day tolar bills and the one-year EURIBOR, are raised for four consecutive quarters (Q4 2006-Q3 2007) before receding to their previous level. Upon the shock, the income implications are derived based on the duration of assets and liabilities. Other input variables are taken from the Economic Projections based on a structural model of the Bank of Slovenia and published in the Monetary Policy Report, October 2006.

The setup of the stress test implies that the interest rate shock reduces the demand for loans and stimulates savings, albeit with a lag and delayed pass-through of higher interest rates on deposits. On the one hand, the non-banking sector responds to the increase in interest rates by reducing new borrowing. The rate of growth of loans to the non-banking sector in 2006 is 0.4 percentage points lower than in the baseline scenario. The growth of total assets follows the growth of loans to the non-banking sector. Current loans require longer to adjust to the new circumstances, which is why most of the impact of the higher interest rates manifests itself only in 2007. On the other hand, higher interest rates stimulate saving, although with a delay. In the case of a higher rise in interest rates, the non-banking sector would allocate disposable income for the early repayment of current loans rather than for deposits. Higher interest rates could encourage the transfer of funds from alternative investments into bank deposits, although this shift is not immediate and only partial.

In another test, a net interest rate margin shock of 0.5 percentage point is assumed to take place in the fourth quarter of 2006 and reverse one year later. As opposed to the interest rate stress test, the interest margin shock is modeled to affect only interest expenses, while the interest rate shock affects both interest expenses and revenue. The margin shock is assumed to leave the balance sheet structure unaffected. The drop in the interest rate margin tries to mimick a rise in the cost of foreign funding. A corresponding rise in foreign interest rates would be highest in the first quarter of the shock, rising by 2.3 percentage points. In subsequent quarters, the interest rate rises less ( 2 percentage points in the second quarter, 1.9 in the third and 1.8 in the fourth quarter) due to base effects.

\section{Liquidity stress test}

The liquidity ratio is defined as the ratio between liquid assets and short-term liabilities. Based on Boss and others (2004), liquid assets are defined as the sum of interbank assets, cash reserves, government bonds available for sale, debt instruments and equities held for trading, and other short-term non-banking sector assets. Short-term liabilities are defined 
as the sum of liabilities to foreign banks, liabilities to domestic banks and short-term liabilities to the non-banking sector. ${ }^{23}$

The liquidity shock assumes that foreign banks withdraw their short-term funding and force Slovene banks to liquidate their short-term assets accordingly. Upon the reduction of short-term liabilities to foreign banks, the assets side is adjusted by liquidating the most liquid assets first before rationing long-term credit business. Depending on the need to reduce short- and long-term credit activities, the impact on profits is calculated on base of current weighted interest margins.

${ }^{23}$ See Boss and others (2004). 


\section{References}

Bank of Slovenia, 2006a, Financial Stability Report, May 2006.

Bank of Slovenia, 2006b, Monetary Policy Report, October 2006.

Belaisch, A., Kodres, L., Levy, J., and Ubide, A., 2001, "Euro-Area Banking at the Crossroads," IMF Working Paper No. 01/28. (Washington: International Monetary Fund).

Boss, M., G. Krenn, M. Schwaiger M., and W. Wegschaider, 2004, "Stress Testing the Austrian Banking System," Bank-Archiv, Austrian Society for Bank-Research, ÖBA 11/2004, pp 841-56.

International Monetary Fund, 2004, FSSA Update, IMF Country Report No. 04/137 (Washington: International Monetary Fund)

International Monetary Fund, 2007, Global Financial Stability Report, April 2007, Chapter III (Washington: International Monetary Fund). 


\section{ISSUeS WITH CAPITAL MARKet DEVELOPMENT IN SLOVENIA ${ }^{24}$}

\section{Summary}

- $\quad$ Slovene capital markets remain less developed than their EU peers, and financial market integration with the EU is only starting. The supply of investment instruments and the investor base are narrow, while infrastructure is gradually being integrated with EU markets.

- $\quad$ Deeper capital markets and greater financial integration with the EU would foster growth and financial stability by providing financing alternatives for companies, especially for SMEs, new or leveraged domestic enterprises, and would help diversify risks and accumulate pension savings.

- $\quad$ To develop capital markets, Slovenia should follow a hybrid strategy that removes obstacles to deeper integration with EU capital markets and constraints on domestic market development to meet local needs.

\section{A. Introduction}

\section{The Slovene financial sector is less developed than that of countries in Europe} with similar incomes. Despite strong credit growth in recent years, bank assets, at 40 percent of the EMU average in 2005, are well below those in EMU peers. Intermediation in Slovenia relies mostly on the banking system with established lending relationships. The development of the non-bank financial sector is even more behind EMU peers - their assets, at about

\begin{tabular}{|c|c|c|c|c|c|}
\hline \multicolumn{6}{|c|}{$\begin{array}{c}\text { Financial System by Assets, } 2005 \\
\text { (Percent of GDP, EMU=100; end of period) }\end{array}$} \\
\hline & \multicolumn{4}{|c|}{ Slovenia Portugal Spain Greece } & EMU \\
\hline Total assets of credit institutions & 39 & 86 & 84 & 55 & 100 \\
\hline Total investment of insurance corporal & 21 & 63 & 52 & 14 & 100 \\
\hline Total assets of pension funds & 26 & 125 & 81 & 0 & 100 \\
\hline Total assets of investment funds & 14 & 42 & 44 & 21 & 100 \\
\hline
\end{tabular}
20 percent of EU average, were half of those in Portugal. Integration with EU markets is also only beginning.

\section{Capital market development would enhance growth potential and reduce}

vulnerabilities. A number of studies have pointed out that greater reliance on capital markets can improve access to finance by new and innovative enterprises. ${ }^{25}$ This is important in Slovenia that has to compete by increasing productivity and technological upgrading of production. By improving access to equity, a more diversified financial system can also reduce vulnerabilities, for example, from high reliance on debt financing in Slovenia.

\section{Capital market development can also contribute to financial stability. More} diversified and liquid markets could attract investments from Slovene institutional investors

\footnotetext{
${ }^{24}$ Prepared by Jochen Andritzky (MCM).

${ }^{25}$ See WEO (2006).
} 
that currently prefer to invest abroad. International integration can enable all types of investors, including retail investors, to maintain a diversified global portfolio and better manage risks. A broader investor base could enable companies to raise capital from the local market at lower costs, and banks can develop alternative sources of revenue from investment services. More open financial markets would also increase transparency and accountability. This would support the overall stability of the financial system.

65. EU integration and euro adoption are both an opportunity and challenge for capital market development for a small country like Slovenia. With the removal of currency risk and the adoption of EU directives, the scale and scope of Slovenia's financial integration with the EU is set to deepen. This can bring sizeable benefits for Slovenia by overcoming the problems with the small domestic market. At the same time, it will complicate capital market development at home by greater competition and pressure to find niche markets with a local comparative advantage. Slovenia's situation is therefore indicative for many other smaller emerging countries that move towards integration with an established market, such as the other new EU member states.

\section{This study recommends a hybrid strategy for capital market development in}

Slovenia. The study first takes stock of the current state of development of Slovene capital markets. It then develops a hybrid approach to capital market development that deepens the integration with European capital markets while preserving a local market segment that is tailored to the needs of domestic issuers.

\section{B. State of Development of the Slovene Capital Markets}

67. Key indicators of market development show that Slovene capital markets remain underdeveloped in terms of relative and absolute size. Despite recent growth in market capitalization, equity turnover has remained low. While the number of outstanding bonds point to a considerable market size, most bonds are illiquid. Despite a deregulation of investment restrictions and a pension reform, assets under management of pension and mutual funds and insurance companies are low.

Capital Market Key Indicators

\begin{tabular}{lrr} 
& Slovenia & \multicolumn{1}{c}{ EU } \\
\hline Equity market capitalization (in percent of GDP), end-2006 & 42.1 & 82.8 \\
Equity market turnover ratio, end-2005 (in percent) & 9.1 & 90.8 \\
Outstanding domestic bonds (in percent of GDP), end-2005 & 22.4 & 88.1 \\
Assets under management (in percent of GDP), end-2005 & 20.6 & 115.3 \\
\hline Sources: BIS, EMDB, OECD, staff calculations.
\end{tabular}




\section{Capital market size and volume}

\section{Equity market capitalization} doubled last year, but trading remains thin. Rising stock prices, capital increases, and a listing of a large enterprise (Telekom Slovenije) boosted equity market capitalization to 42 percent of GDP in 2006. Although this makes Slovenia's equity market comparable to Germany in relative terms, liquidity is thin by EU standards, pointing to low market activity.

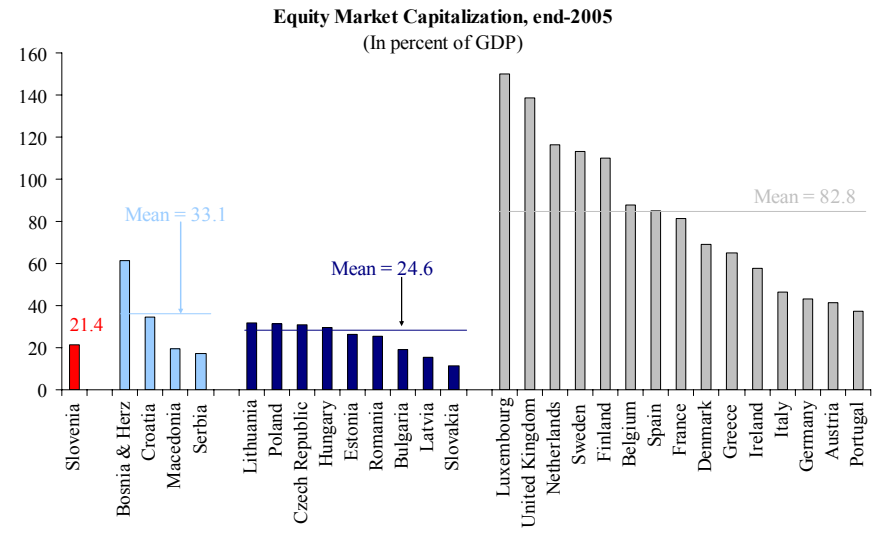

Sources: EMDB; Belgrade Stock Exchange; Bratislava Stock Exchange; Ministry of Finance, Macedonia and WEO.

Equity Turnover Ratios, end-2005

(In percent)
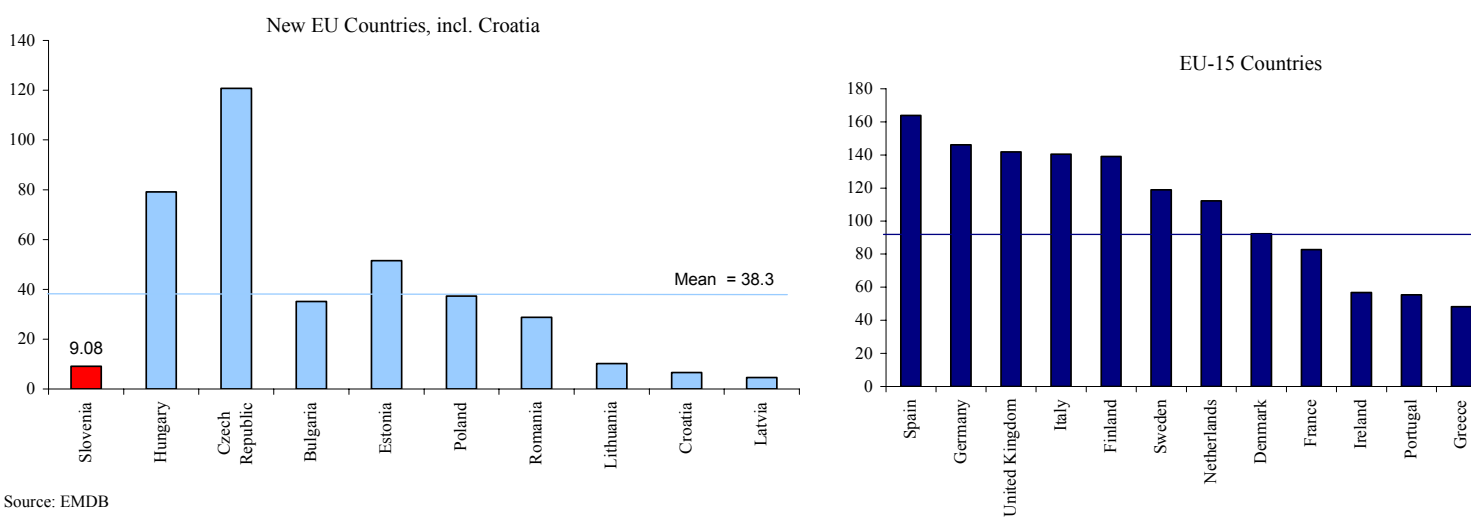

69. Most trading takes place off market, thereby reducing transparency and market information. About one-third of the total trading volume, and 41 percent of equity trading took place off-market ("unofficial market") in 2005. Furthermore, block trades (large transactions that are bilaterally negotiated) accounted for another 16 percent of total trading volume, and 27 percent of equity trading in 2005. These practices have made regular trading volumes at the Ljubljana Stock Exchange (LJSE) small and relatively illiquid. The dominance of these negotiated deals differentiates the LJSE from more established stock exchanges, which usually have a smaller share of negotiated deals and require more timely reporting.

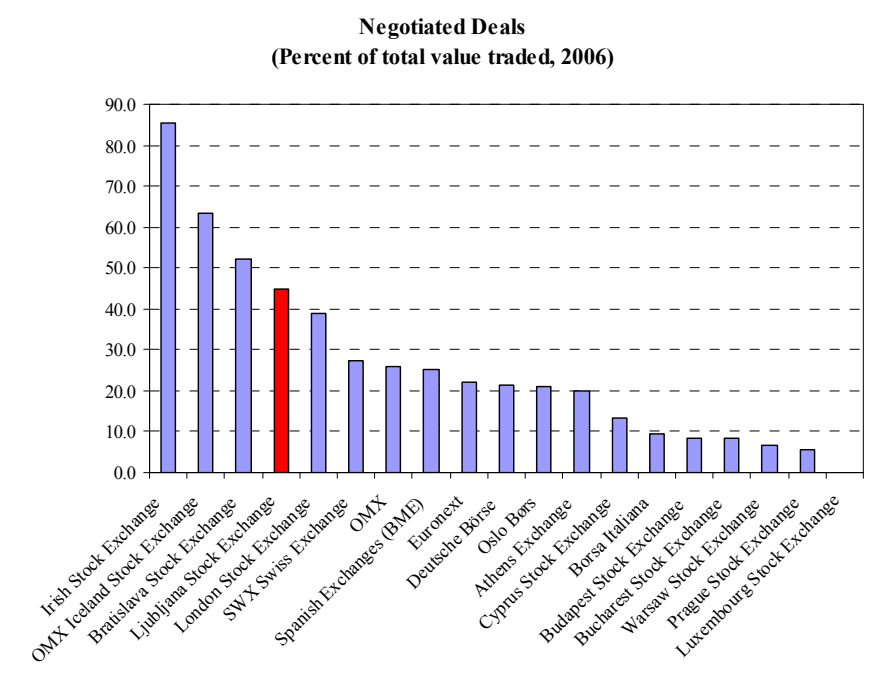


70. The relative size of the local bond market is similar to that in the other new EU member states, but smaller than that of EU peers. The amount of outstanding bonds stood at 22 percent of GDP in 2005. Three quarters of the total consists of government bonds, while the rest are mostly bonds issued by local banks.

\section{The dominance of bank finance and competition from EU sources have complicated bond market development.}

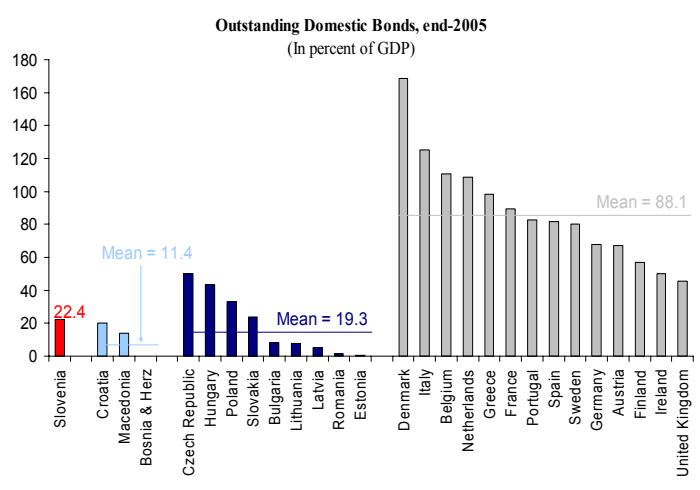

Sources: BIS; Local authorities; Deutsche Bank; Fitch Polska; Cbonds; Erste Bank and WEO.

Alternative sources of funding for corporates, mostly from banks that refinance in the EU, is abundant. This makes bond finance more expensive than loan financing for non-financial corporations. Furthermore, despite recent efforts to develop a special local market (the "TUVL"), government bond issuance is set to migrate to the euro market that can finance larger volumes with lower spreads (Box 1). This is a good example of problems faced by small economies in capital market development with greater international integration.

\section{Box 1. The Rise and the Fall of TUVL}

An over-the-counter trading platform for government bills and bonds, named the "TUVL", was created in Slovenia in September 2005 to increase market liquidity and transparency. To promote trading, the issuer assumed the trading cost, and clearing costs were negotiated to be less than 10 percent of the normal fee levied.

The initiative helped to concentrate the formerly fragmented trading activity and greatly reduced trading costs. Trading volume increased by eight times in the first month of operation and the average trade size doubled. Pre- and post-trade transparency improved as market maker quotes were accessible through a public web page maintained by the LJSE.

While the creation of the TUVL is a good example of how a concerted initiative can boost liquidity and transparency of the trading activity, it also points to the difficulties of capital market development in small countries with increasing international financial integration. Trading volumes at the TUVL declined recently when issuance activity migrated to the euro government bond market (using the panEuropean MTS trading platform). Although this will cease local trading, the adoption of MTS brings significant advantages, such as better access to foreign investors and the possibility to implement the MTS repo facility. Given that the initial investments in the TUVL infrastructure did not pay off, this case also illustrates the need to develop a long-term strategy for capital market development. 


\section{Trading in other financial instruments, such as derivatives or structured}

products, is virtually nonexistent. Repurchase transactions ("repos") are conducted mostly outside Slovenia, which is more cost efficient and less cumbersome. For similar reasons, securities borrowing and lending transactions are rare, and there have been no issues of asset backed securities (ABS). With regard to derivatives, some currency and interest rate products are traded over the counter and a few exchange traded funds (ETFs) are listed at the LJSE.

73. The EU integration process has started. Until recently, bank loans from abroad were the main source of integration with EU financial markets. However, compliance with EU directives, such as for investment services ("ISD") and collective investments ("UCITS"), set off a process that ultimately will lessen the importance of national borders. After Slovenia lifted the investment restrictions on mutual funds, the share of foreign securities in domestic portfolios increased substantially. At the same time, funds domiciled elsewhere in Europe have been launched in Slovenia, and currently outnumber domestic funds. Certificates on the local stock exchange index have also been listed in Frankfurt and Vienna. This has attracted the attention of international investors and improved liquidity, as selling the certificate requires the issuer to hedge on the local market.

\section{Issuer and investor base}

\section{The supply of investable instruments has been limited due to the small market} size and reliance on other sources of finance. The number of issuers of bonds or stocks has been low, partly because of the limited number of sizable companies in Slovenia and the absence of listings from abroad. The government still holds important stakes in many financial and other enterprises and, apart from Telekom Slovenije recently, has not actively pursued their listing on the stock exchange. Privatizations, which in some countries have helped create an investor base, have mostly been conducted by private placements instead of public offerings at the stock exchange.

\section{Despite recent growth, the investor base remains small and concentrated.}

Compared to EU peers, the institutional investor base is shallow. However, the investment fund industry is growing strongly. Since the relaxation of foreign investment restrictions in 2001, private savings are increasingly channeled into mutual funds. Direct participation of retail investors has remained low given the absence of discount brokerage services. Foreign investors are increasingly present (as inward investment in securities has grown to 12 percent of all Slovene securities) and contribute to trading liquidity at LJSE: As active market participants, foreign investors have a 2.3 times higher turnover ratio than domestic investors.

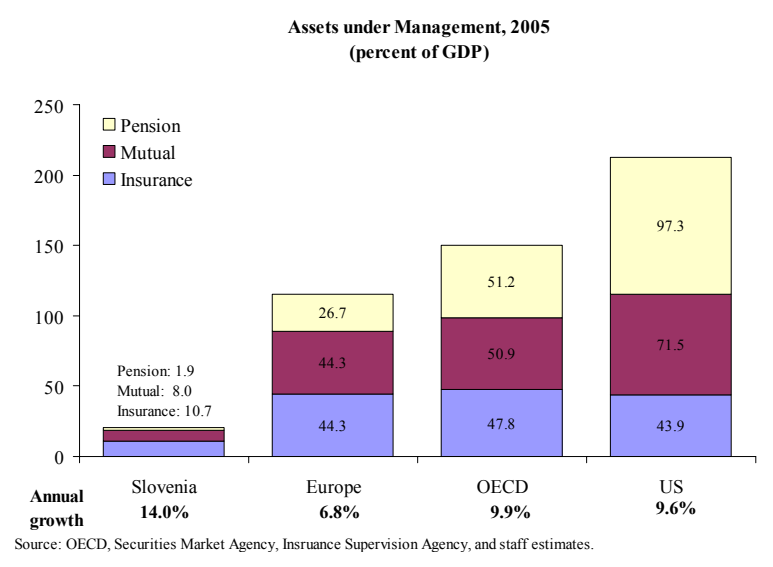


Therefore, foreigners provide liquidity and contribute disproportionately to price formation.

76. The small share of the free float reduces trading liquidity. There is a strong positive relationship between free float and stock market turnover. In Slovenia, the free float capitalization of the prime market (the most liquid segment at the LJSE), at 61 percent of the total capitalization, is relatively low compared to, for example, the DAX ( 88 percent) ${ }^{26}$ This points to a concentration of ownership in many Slovene companies. For 18 smaller companies, for which data is available, the free float stands at only 35 percent.

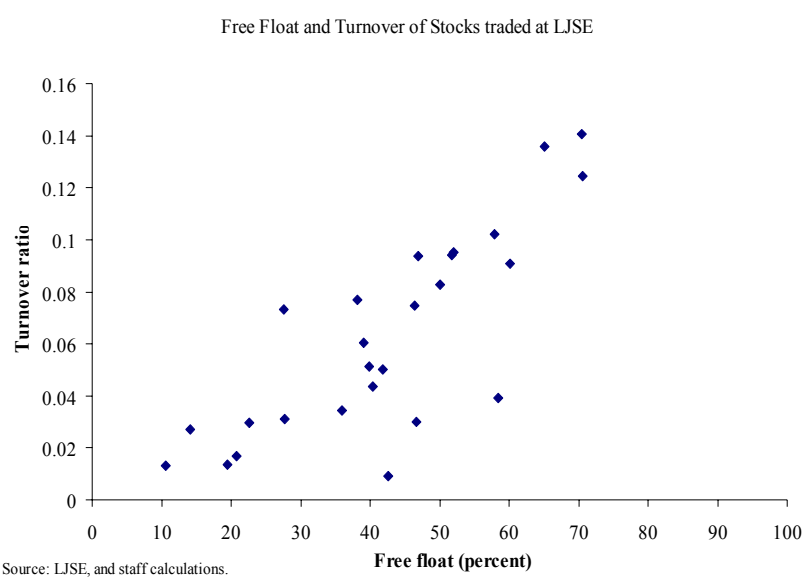

77. Given the limited demand and supply of securities, capital is not raised by initial public offerings (IPOs). With the small number of potential buyers, companies consider an IPO to be too expensive vis-à-vis a private sale. Larger issuers would need to consider listing abroad given that the onshore market does not offer sufficient absorptive capacity. Since listing in an illiquid market does not bring the benefits of deep capital markets, corporations prefer to remain unlisted given the direct and indirect costs of compliance with the stock exchange's transparency rules. Thus, the limited supply and demand of investable securities has become self-reinforcing.

\section{Infrastructure and regulation}

78. The only organized market for securities trading in Slovenia is the LJSE. The LJSE offers trading of equities, bonds, and investment funds. Order book trading is conducted through a trading system called BTS, while block trades are negotiated bilaterally and reported to BTS once a day. The large over-the-counter (OTC) market ("unofficial market"), which accounts for one third of the overall trading activity, does not use any specific trading infrastructure. However, some investors, such as investment funds, are restricted from engaging in off-market trading.

\footnotetext{
${ }^{26}$ The free float is defined as all shareholdings of less than 5 percent of total market value.
} 
Trade Volume in 2006

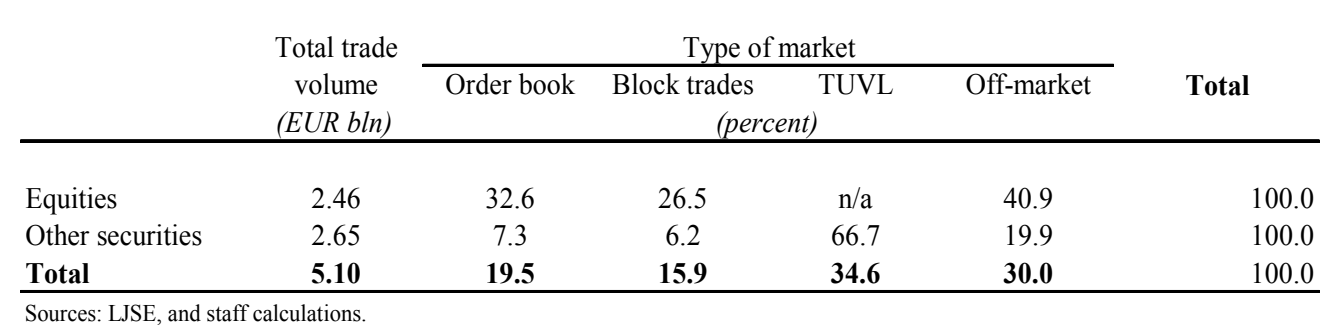

Sources: LJSE, and staff calculations.

79. Slovenia's one clearing and depository house has relatively high settlement costs. Post-trade services are handled by Centralna klirinško depotna družba (KDD), the central securities depository (CSD) in Slovenia.

Given the relatively high fixed cost in the business and small volumes, settlement costs in Slovenia are Operating income per transaction (in euro) higher than in other national CSD in Europe or in the US.

\begin{tabular}{|c|c|c|c|c|}
\hline \multicolumn{5}{|c|}{ Operating income per transaction (in euro) } \\
\hline & \multirow{2}{*}{ Slovenia } & \multicolumn{2}{|c|}{ EU average } & \multirow[t]{2}{*}{ US } \\
\hline & & via CSD & via ICSD & \\
\hline Post-netting & $3.80 / 1$ & 2.98 & 5.14 & 2.77 \\
\hline Pre-netting & 3.80 & 1.49 & 2.86 & 0.46 \\
\hline
\end{tabular}

80. The regulatory framework is in transition, largely to comply with EU directives. Slovenia has adopted all relevant EU capital market-related Directives, most recently the Prospectus Directive by amending the Securities Market Act. By drafting a new law on financial instruments, Slovenia strives for a timely transposition of the Markets in Financial Instruments Directive (MiFID), that extends the range of investment services that firms can passport (i.e., make them transferable to any EU country). ${ }^{27}$ The directive also strives to harmonize the organization and conduct of the investment business, for example by improving transparency requirements for equity markets. Given the complexity of the issues, it remains to be seen whether the new law can accommodate the full scope of MiFID principles, and to what extent it fosters financial integration with the EU. Takeover legislation and capital gains taxation in Slovenia are in line with common practice in the EU. Important regulatory barriers exist in the pension and insurance sector, such as the minimum return requirement on investments that effectively limits risk taking.

81. Financial sector supervision is fragmented. Bank supervision is located at the central bank, the Securities Market Agency is in charge of financial market supervision, including market activity and mutual funds, and the Insurance Supervision Agency covers insurances and pension companies and funds. Consolidating the activities, as currently

\footnotetext{
${ }^{27}$ An example are investment funds compliant with EU regulations that can be marketed in all EU countries.
} 
planned by the authorities, could help streamline administrative procedures and improve the effectiveness of capital market supervision.

\section{Developing Capital Markets in Slovenia}

82. Capital market development in a small country like Slovenia has to balance the objectives of local market development and deeper integration with EU markets.

Slovenia already has a basic infrastructure in place, that can be used to further develop local markets for the needs of investors and issuers. Given its trade and investment links in Southeastern Europe, Slovenia may also find some niches in the region. At the same time, European financial integration is advancing rapidly, and small markets can derive large benefits from participating in this process. International integration mitigates some of the size-related obstacles, such as diversifying the investor universe, attracting trading liquidity, and enlarging the funding capacity. This means that Slovenia should develop a hybrid strategy that pursues integration with international capital markets and continues to enhance domestic capital markets.

\section{Integrating Slovene markets with international capital markets}

83. While benefits from deeper integration with foreign markets can be large, they are not without risks. Consolidation of trading and settlement venues can lead to direct cost savings for market access and trading from scale effects, which can be further enhanced by competition. ${ }^{28}$ By integrating the investor and issuer base, international markets can offer a higher degree of diversification opportunities and lower risk premia. ${ }^{29}$ From a national perspective, the main risk of financial integration is the loss of policy independence. Another risk is fragmentation of liquidity from migration to several exchanges and trade diversion, if they are not linked. ${ }^{30}$ This has happened, for example, in Latin American equity markets (de la Torre and Schmukler, 2007), but not yet in Europe (BIS, 2001, p. 21).

\section{Against this background, deeper international integration in Slovenia should} cover measures to globalize the investor base, integrate the infrastructure, and harmonize other regulations, taxation, and supervision. The globalization of the investor base can be achieved by removing constraints to international investors establishing presence in domestic markets, and to domestic issuers migrating to foreign markets. As with infrastructure and regulation, much of this is guided by EU regulations.

\footnotetext{
${ }^{28}$ Competition among specialists that lead to lower bid-ask spreads has been found by Domowitz and others (1998).

${ }^{29}$ Hardouvelis and others (2006) show that the costs of equity capital decreased upon integration into the EMU.

${ }^{30}$ See Levine and Schmukler (2003).
} 


\begin{tabular}{|c|c|c|}
\hline & Achievements in Slovenia & Future Actions \\
\hline $\begin{array}{l}\text { Globalization of } \\
\text { investor base }\end{array}$ & $\begin{array}{l}\text { - EU accession and euro adoption } \\
\text { - Lifting of foreign investment } \\
\text { restrictions } \\
\text { - Authorization of foreign funds and } \\
\text { issuers } \\
\text { - Education and roadshows }\end{array}$ & $\begin{array}{l}\text { - Increase attractiveness of local market } \\
\text { (see following section) } \\
\text { - Review indirect barriers to foreign } \\
\text { investors in Slovenia }\end{array}$ \\
\hline $\begin{array}{l}\text { Integration of } \\
\text { infrastructure }\end{array}$ & $\begin{array}{l}\text { - Cooperation with foreign exchanges } \\
\text { - Adoption of European MTS trading } \\
\text { platform for bonds }\end{array}$ & $\begin{array}{l}\text { - Strategic partnership with foreign stock } \\
\text { exchange } \\
\text { - Strategic partnership with foreign CSD } \\
\text { - Enable foreign intermediaries to } \\
\text { become trading and settlement members }\end{array}$ \\
\hline $\begin{array}{l}\text { Harmonization of } \\
\text { regulation, } \\
\text { taxation, } \\
\text { supervision }\end{array}$ & $\begin{array}{l}\text { - Reform and harmonization of: } \\
\text { - takeover law and minority shareholder } \\
\text { protection } \\
\text { - market abuse regulation } \\
\text { - capital gains taxation, withholding } \\
\text { taxes, stamp duties } \\
\text { - Double-taxation conventions } \\
\text { - Memoranda of understanding for } \\
\text { supervisory cooperation }\end{array}$ & $\begin{array}{l}\text { - Implementation and enforcement of } \\
\text { MiFID }\end{array}$ \\
\hline
\end{tabular}

85. Further globalization of the investor base requires measures to develop the local capital market and to lower costs of cross-border transactions. Despite recent progress, the limited supply of investment instruments is reducing the attractiveness of Slovenia for foreign portfolio investors. To increase this supply, further development of local markets is needed (see following section). At the same time, Slovene institutional investors have difficulty in competing with larger counterparts in the rest of Europe due high costs of setting up market presence abroad. These costs can potentially be reduced by achieving scale effects and the gradual decrease in costs from cross-border competition. Market participants also note that the existing legislation entails some indirect barriers to foreign participation in local markets that should be further studied.

\section{European integration has led to a consolidation among stock exchanges,} lowering costs for trading; however, the integration of post-trading services lag behind. The consolidation among stock exchanges is expected to continue, further catalyzed by the MiFID. Apart from the common passport discussed above, the directive for an EU wide approach to market regulation could further level the playing field between regulated cash markets, unregulated cash markets, and institutions that internalize trades (i.e., match orders in house). While progress with integrating the trading infrastructure is remarkable, international integration of post-trading services is lagging behind. The currently complex and fragmented environment of clearing and settlement services, which imposes costs, risks, and inefficiencies on investors, institutions, and issuers, has recently alerted EU regulators. The EU Commission has since stepped up efforts to ensure better implementation and 
monitoring of existing directives in this area (the Settlement Finality Directive and the Financial Collateral Directive), and to establish a system for settlement between European clearing and depository houses ("Target2S").

\section{As a small player in the EU context, the LJSE is likely to integrate with}

European exchanges. LJSE has received takeover offers from various European exchanges, including OMX and the Warsaw Stock Exchange. This would benefit Slovenia by a improving access to new technology and trading facilities developed by the partner, and to a broader investor base. Using a joint trading platform under harmonized rules within the network of a pan-European exchange would immediately widen the investor base, as the existing users of this exchange could seamlessly access Slovenia's capital market.

88. The clearing and depository agency should also continue to integrate with other markets to sustain business. After the migration of government bond trading abroad the local clearing agency (KDD) is facing stagnant business. Its settlement facility is designed for a small capital market, limiting its functionality in the European context. KDD is currently marketing its system to other small markets, such as Bosnia-Herzegovina and Angola. Other avenues for future business can include enabling foreign intermediaries to become trading and settlement members, for instance, by making the fee structure internationally competitive and establishing bilateral settlement links to large international centralized securities depositories (ICSDs).

89. Progress in adopting EU-related regulatory reforms has been remarkable, while implementation of MiFID will become key to advance integration. The Securities Market Act was amended to accommodate the EU directive on prospectuses and the directive on market abuse. The revised Takeover Act provides minority shareholder protection along the lines of the EU Takeover Directive. Double-taxation conventions are in place with relevant countries, and memoranda of understanding have been signed for cross-border supervisory cooperation. Going forward, rigorous implementation and effective enforcement of MiFID will be the key for further integration. Its transposition into national law is currently lagging behind schedule in many EU countries. Slovenia has entered the drafting stage but, as of April 2007, has not yet notified the Commission of the transposition.

\section{Domestic capital market development}

90. Local market development in Slovenia has many advantages. Given the high cost of foreign listings, better access to local equity finance can help Slovene enterprises to reduce their high reliance on debt-financing. Capital markets can also provide equity funding that, by its nature, is better compatible with long-term investment projects than bank funding, especially so for young enterprises that do not yet generate significant cash flows or service companies that lack asset collateral. Stock markets allow investors to participate in long-term projects while offering the chance to sell their stakes if needed. Likewise, the stock market opens venture capital investors a way to exit from their investments once they matured, 
thereby freeing capital to be invested once again. Development of new investment products such as venture capital, pension and investment funds or derivatives can also better diversify risks and funding sources.

91. Deepening the local capital market in Slovenia requires measures to enlarge the investor base and the availability of investable securities, coupled with more progress on developing infrastructure and regulations.

\begin{tabular}{|c|c|c|}
\hline & Achievements in Slovenia & Future Actions \\
\hline Investor base & $\begin{array}{l}\text { - Establishment of investment funds } \\
\text { - Promoting pension savings in the form } \\
\text { of pension funds }\end{array}$ & $\begin{array}{l}\text { - Removal of remaining investment } \\
\text { restrictions } \\
\text { - Expanding the presence of hedge funds } \\
\text { and venture capital funds } \\
\text { - Promote direct retail and foreign } \\
\text { investor participation }\end{array}$ \\
\hline $\begin{array}{l}\text { Universe of } \\
\text { investable } \\
\text { securities }\end{array}$ & $\begin{array}{l}\text { - Sophisticated public debt management } \\
\text { to maintain liquid benchmarks } \\
\text { - Market segments with different } \\
\text { requirements for liquidity and } \\
\text { transparency }\end{array}$ & $\begin{array}{l}\text { - Listing of large companies } \\
\text { - Measures to increase the free float } \\
\text { - Promotion of best practice for good } \\
\text { corporate governance } \\
\text { - Introduction of market segment for } \\
\text { SME } \\
\text { - Facilitate ABS issuance }\end{array}$ \\
\hline Infrastructure & $\begin{array}{l}\text { - Rule book (listing, trading) along } \\
\text { international standards } \\
\text { - Adoption of bond trading platform } \\
\text { - Integrated settlement for all products }\end{array}$ & $\begin{array}{l}\text { - Expanding pre- and post-trade } \\
\text { transparency } \\
\text { - Setting incentives for consolidation of } \\
\text { trading activity for deeper order books } \\
\text { - Use of market makers } \\
\text { - Demutualization of CSD }\end{array}$ \\
\hline $\begin{array}{l}\text { Regulation and } \\
\text { supervision }\end{array}$ & $\begin{array}{l}\text { - Capital market legislation } \\
\text { - Independent supervisory agency }\end{array}$ & $\begin{array}{l}\text { - Derivatives law } \\
\text { - Strengthening of non-bank supervision } \\
\text { cross-market cooperation } \\
\text { - Streamlining of administrative } \\
\text { procedures }\end{array}$ \\
\hline
\end{tabular}

\section{To diversify the investor base, restrictions on portfolio selection should be}

reduced. The removal of foreign investment restrictions in 2001 enhanced portfolio diversity by incorporating foreign securities, but additional measures are needed to allow for more flexibility with various investment products. In particular, the requirements for a minimum required return for pension funds, and restrictions on investments in the unregulated market limit portfolio selection of investable securities. By allowing, for example, the operation of funds not compliant with EU legislation (i.e., non-UCITS compliant funds) with more risky strategies (including derivative and leveraged investments) could facilitate the establishment of hedge fund products. Hedge funds contribute to widening the choice of risk-return profiles and, by pursuing active investment strategies, improve trading liquidity. Direct participation of retail investors in the market is hampered by high brokerage fees and the lack of easy-toaccess internet-based brokerage services. Direct access of foreign investors is limited by the high set-up costs of local market presence, which, together with the limited investment opportunities offered, makes such an investment unattractive. 


\section{The supply of securities would be enlarged by listing more companies at the} stock exchange. Listing of companies in which the state holds a significant stake would be a start. In particular, listing of state-dominated financial companies would greatly enhance the universe of investable securities. Implementing the current bank privatization program, that includes a secondary offering of one of the banks - as opposed to a private sale - would draw attention to the equity market and could, by using appropriate allocation rules, increase the free float. The listing of Telekom Slovenije in 2006 is a good example for how the privatization process contributes to the development of capital markets. The secondary listing of the Telekom has roughly doubled the market capitalization and added an actively traded stock that has already been incorporated in the local market indices.

\section{Other measures that should be taken to enhance the supply of products are encouraging companies to present themselves for capital markets, and actively promoting the development of financial innovations, such as asset-backed securities.} Weak corporate governance can make companies shy away from oversight by market participants. Recent efforts at raising corporate governance standards up to EU levels could make more companies go public. Initiatives for capital market education should complement this effort. Besides putting necessary legislation for innovative financial products in place, issuance could also be jump-started, as was done in Spain, by a concerted initiative (see Box 2). However, when considering the use of credit enhancement schemes, such as state guarantees, policy makers need to ensure that they are designed carefully to avoid fiscal contingencies, moral hazard, and reputational risks.

\section{Box 2. SME Securitization: The Spanish Case}

Since late 1990's, several European countries, including Germany and Spain, have incorporated securitization into their SME programs with some types of government guarantees. Similar efforts are also underway in other regions - for example, Singapore launched an SME Loan Access program in 2005.

The mechanics of the program can be described with the example of Spain. An originator puts SME loans to a special purpose vehicle (SPV). The Treasury commits to guarantee specific tranches issued by the relevant SPV, provided that the originator holds a minimum percentage of bank loans to SMEs in its portfolio. In return for the liquidity gained through the sale of the SME loans, the originator commits to reinvest part of this liquidity in SME financing. The scheme is supported by a master agreement that every securitization fund has signed with the Ministry of Economy.

Approximately 60 Spanish banks have participated in the scheme. In a few cases, SME portfolios from several banks have been packaged into one single securitization transaction (i.e. multiorigination). In 2004, SMEs securitization in Spain amounted to 18 percent of the total volume of securitization issuance--EUR 9 billion out of a total issuance volume of EUR 52 billion.

Principal author: Ana Carvajal (MCM-CD). 
95. To improve local infrastructure, trading and settlement systems should be aligned with international standards. Listing and trading rules at LJSE are broadly in line with international practice. The demutualization of the LJSE has transformed the stock exchange into a "for profit" entity that is better positioned to cope with increasing competition. Similarly, the demutualization of KDD would put the local clearing and depository house on equal footing with competitors.

96. Order-book trade flow and transparency of trading activity could greatly be improved. More rigorous reporting requirements for off-market trades would improve transparency with regard to type, amount, and price of securities traded, as envisioned by the MiFID. Measures such as the fee structure or timely reporting requirements could also be considered to align block trading with order-book trading, or at least reduce the dominance of negotiated deals. More immediate reporting requirements, as facilitated by a trading facility for negotiated trades, could improve post-trade transparency that caters to order book trading. Creating incentives by adjusting the fee structure, or increasing the minimum size of block trades could increase the relative attractiveness of order book trades. Furthermore, promoting the presence of market makers could greatly enhance the liquidity of small and less traded stocks. The low interest of brokers to engage in making markets can be traced back to the lack of automated market maker facilities which would greatly reduce costs compared to maintaining continuous quotes manually.

\section{Further strengthening surveillance and enforcement will be required as the} domestic market expands. The authorities recognize the need to strengthen cross-market surveillance and believe that unifying banking, financial market, and insurance supervision under one roof may be effective in improving current efforts. Furthermore, surveillance capabilities of financial markets could be stepped up. For instance, improvements in the IT infrastructure can help to detect market abuse by better monitoring trading activity. The introduction of new financial products, such as derivatives, requires developing an adequate surveillance framework, ideally supported by a derivatives law. ${ }^{31}$

\section{Capital market development would also benefit from better internalization of an}

"equity culture." European financial culture tends to consider market financing as more appropriate for larger companies, while bank financing is for SMEs. The banking system in Slovenia has tended to focus on providing credit to existing clients, rather than to new enterprises. ${ }^{32}$ Better acceptance of market financing could mitigate this situation by directly financing SMEs through stock markets or indirectly through enabling banks to refinance their corporate loan portfolios, possibly by asset-backed securitization. For this to happen, investors need to embrace a financial culture that provides the willingness to deal with the characteristics of SMEs, such as a more volatile business environment, higher bankruptcy rates, innovative business models, and a high share of intangible assets that are hard to evaluate.

\footnotetext{
${ }^{31}$ See Gutierrez (2005).

${ }^{32}$ Studies show that arms-length systems are better at allocating resources to new firms, technologies and activities (WEO, 2006).
} 


\section{Conclusions}

99. Capital market development in Slovenia is best promoted by leveraging the existing local setup in an integrated European market. The size of Slovenia's domestic market is not sufficient to become a thriving market place on its own that can deliver the benefits of a mature capital market. Therefore, a hybrid market model seems best —allowing issuers and investors to reap the benefits of the single European market while preserving a local market segment that fits the needs of domestic issuers.

100. Policymakers can help this process by taking initiatives that further improve the regulatory and supervisory framework and promote an equity culture. The following are key measures that help promote both local capital market development and international integration:

- Structural issues. List state-owned companies with the option to subsequently sell a state-owned stake at the stock exchange; set incentives to foster financial innovation; and support efforts to establish international partnerships for the stock exchange and the clearing and depository house.

- $\quad$ Regulatory issues. Fully implement MiFID as well as EU guidelines for corporate governance; and remove remaining restrictions for local investments by foreign investors as well as foreign investments by locals.

- $\quad$ Supervisory issues. Step up surveillance and enforcement, in particular with regard to transparency in securities trading; and streamline administrative procedures. 


\section{Abbreviations and Acronyms}

ABS Asset backed securities

CSD Central Securities Depository

ETF Exchange traded funds

ICSD International Central Securities Depository

IPOs Initial public offerings

ISD

Investment Services Directive

KDD Centralna klirinško depotna družba

LJSE Ljubljana Stock Exchange

MiFID Markets in Financial Instruments Directive

OTC Over-the-counter

SME

SPV

Small and medium-sized enterprises

UCITS Undertakings for Collective Investment in Transferable Securities 


\section{References}

Bank for International Settlements, 2001, The Implications of Electronic Trading in Financial Markets (Basel: Bank for International Settlements).

de la Torre, A., and S. Schmukler, 2007, Emerging Capital Markets and Globalization (Palo Alto, California and Washington: Stanford University Press and World Bank).

Domowitz, I., J. Glen and A. Madhavan, 1998, "International Cross-Listing and Order Flow Migration: Evidence from an Emerging Market," Journal of Finance, Vol. 53.

Gutierrez, E., 2005, "A Framework for the Surveillance of Derivative Activities," IMF Working Paper 05/61 (Washington: International Monetary Fund).

Hardouvelis, G.A., D. Malliaropulos, and R. Priestley, 2006, "EMU and European Stock Market Integration." Journal of Business, Vol. 79, pp. 365-392.

Levine, R., and S. Schmukler, 2003, "Migration, Spillovers, and Trade Diversion," Policy Research Working Paper No. 3046 (Washington: World Bank). 


\section{A Fiscal Framework for Slovenia ${ }^{33}$}

\section{Summary}

- In the coming years, Slovenia is expected to face significant fiscal challenges as it tries to meet its medium-term fiscal targets while concurrently lowering the tax burden and increasing expenditure flexibility and efficiency. Rapid population aging adds to these fiscal pressures, undermining long run debt sustainability.

- To deal with these challenges, the fiscal institutional framework should be strengthened. Introduction of an expenditure rule, based on a cyclically adjusted deficit, could help enhance the commitment to an expenditure-based consolidation.

- The credibility of the new fiscal framework could be further strengthened by independent assessment of fiscal trends and medium-term fiscal plans and outcomes.

\section{A. Background}

101. As Slovenia enters a new era in the European Monetary Union (EMU), fiscal policy reform has become a key priority. While Slovenia has maintained a favorable fiscal performance with low deficits and debt, sustaining this will be increasingly challenging. The government has embarked on a fiscal reform program that is expected reduce the tax burden significantly over the medium term. The program also envisages lower deficits to achieve structural balance by 2011. Expenditures also need to be restructured to increase budgetary flexibility and enhance the role of fiscal policy has a countercyclical policy tool. Over the longer horizon, age-related spending is expected to increase fiscal burden considerably.

\section{Given these challenges, a strong fiscal institutional framework, including} through fiscal rules, needs to be considered. Effective implementation of the fiscal reform program will require early identification of expenditure reform measures and political consensus to adhere to the government's medium term fiscal targets. A strong fiscal institutional framework could help strengthen commitment and enhance the credibility of the fiscal reform plans.

\section{Against this background, the paper reviews experiences with select aspects of} fiscal rules and makes some policy proposals that could strengthen the fiscal framework in Slovenia. Section B reviews fiscal trends and challenges in Slovene fiscal policy. Section $\mathrm{C}$ discusses the current fiscal framework. Section $\mathrm{D}$ focuses on key features and experiences from the adoption of fiscal rules and independent fiscal institutions in the European Union (EU) and section E discusses policy issues including key considerations for the a fiscal rule in Slovenia. Section F concludes.

\footnotetext{
${ }^{33}$ Prepared by Anita Tuladhar (EUR).
} 


\section{B. Fiscal Policy Developments and Challenges}

104. Slovenia has a history of a sound fiscal policy that has ensured low deficits and debt levels. Debt has remained at around 28 percent of GDP and fiscal deficits, at about $1 \frac{1}{2}$ percent of GDP in 2005, have been among the lowest in the central European new member states (Figure 1) ${ }^{34}$ While revenues and expenditures, as a percent of GDP, are high by regional standards, Slovenia has been gradually lowering them particularly over recent years, through reductions in the payroll tax and containment of public wage bill. This has led to a reduction of the fiscal deficits as well.

105. Despite these favorable developments, Slovene fiscal policy does not appear to have demonstrated a strong countercyclical property. Such a countercyclical role for fiscal policy will be increasingly important for Slovenia as a member of the European Monetary Union. Although the data series for measuring economic cycles are relatively short, fiscal performance over 2000-03 suggests that even as the output gap turned negative and widened, cyclically adjusted balances narrowed from a deficit of almost 4 percent of GDP to 2 percent (Figure 2). This trend likely reflects discretionary measures for fiscal consolidation as part of EU entry preparations, mainly on the revenue side. Since 2004, however, the cyclically adjusted deficit has been stable, reflecting an acyclical stance as the output gap narrowed. This was marked by reductions in both the revenue and spending sides.

\section{Therefore, one key challenge for Slovene fiscal policy is consolidation of} budgetary spending to enhance flexibility. This would improve the discretionary scope to run countercyclical policy as well as create fiscal space for age-related spending pressures. A cross country comparison of expenditure structure shows that Slovenia has a rigid budget structure with a relatively high share of nondiscretionary spending (IMF, 2006a). This has led to measures to reduce mandatory spending including through reindexation of social benefits to inflation. Cross-country analysis of expenditure efficiency suggest scope for efficiency gains in certain areas of mandatory spending such as education,

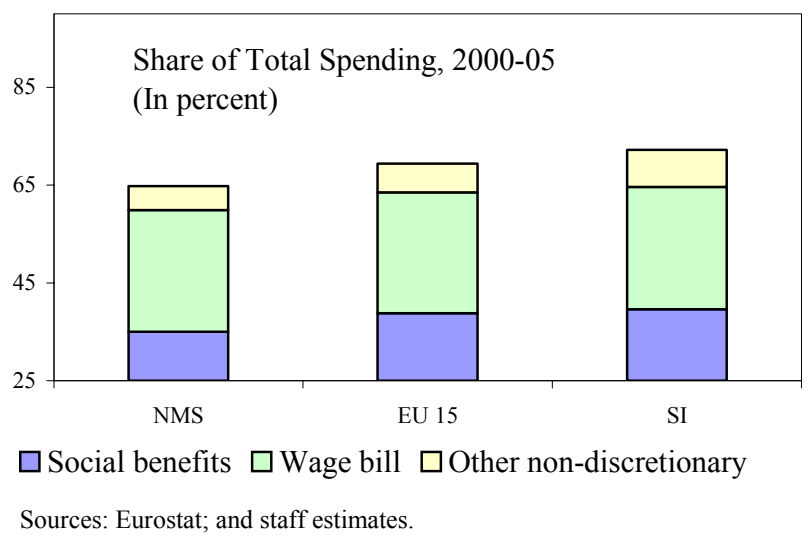
health and social transfers.

\footnotetext{
${ }^{34}$ Fiscal data in this paper are presented on ESA-95 basis.
} 
Figure 1. Slovenia and NMS-8: Fiscal Indicators, 2000-09
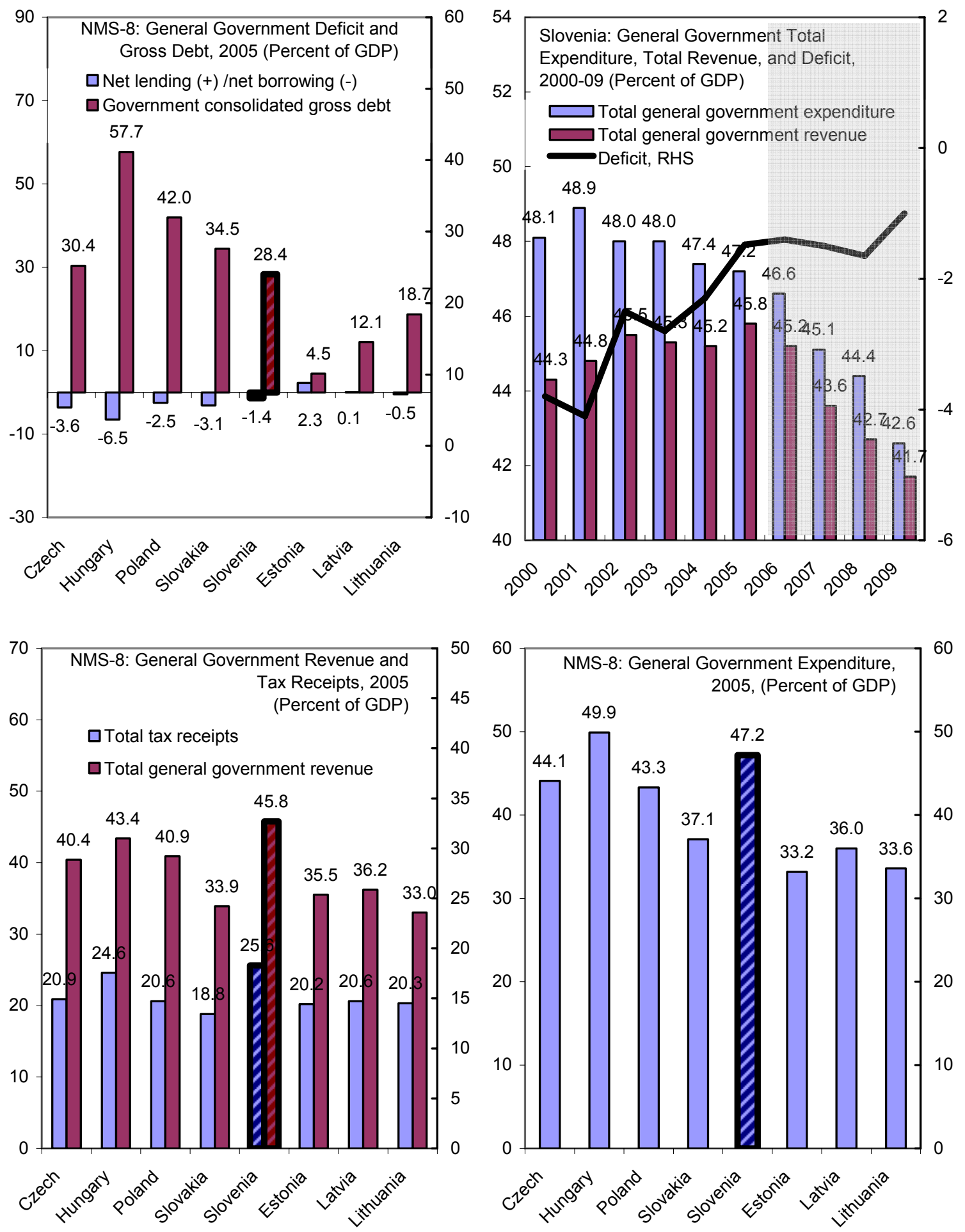

Source:Eurostat, Ministry of Finance of the Republic of Slovenia. 
Figure 2. Slovenia: Indicators of Fiscal Stance, 2001-06
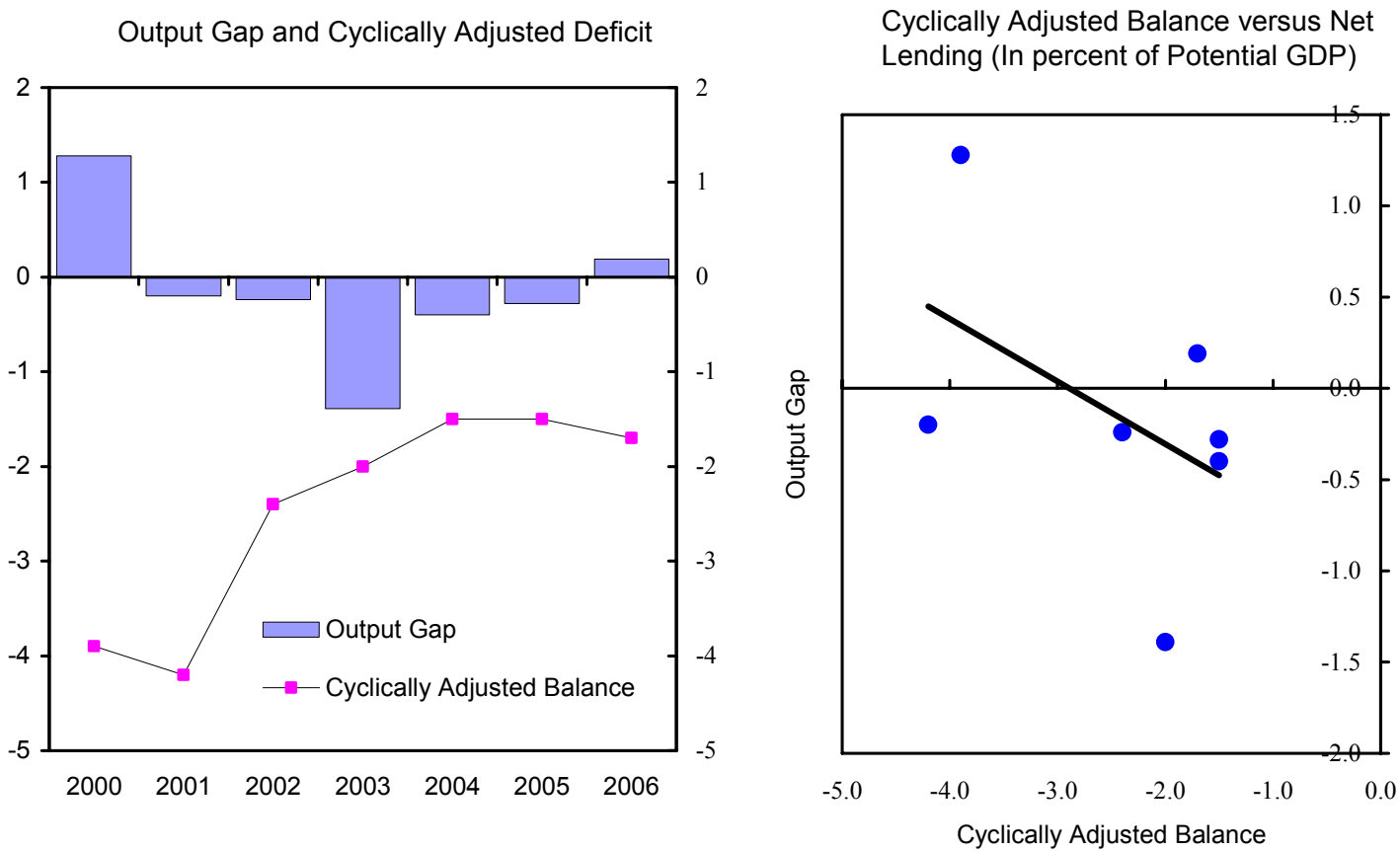

Decomposition of the Change in Deficit (In percent of GDP)

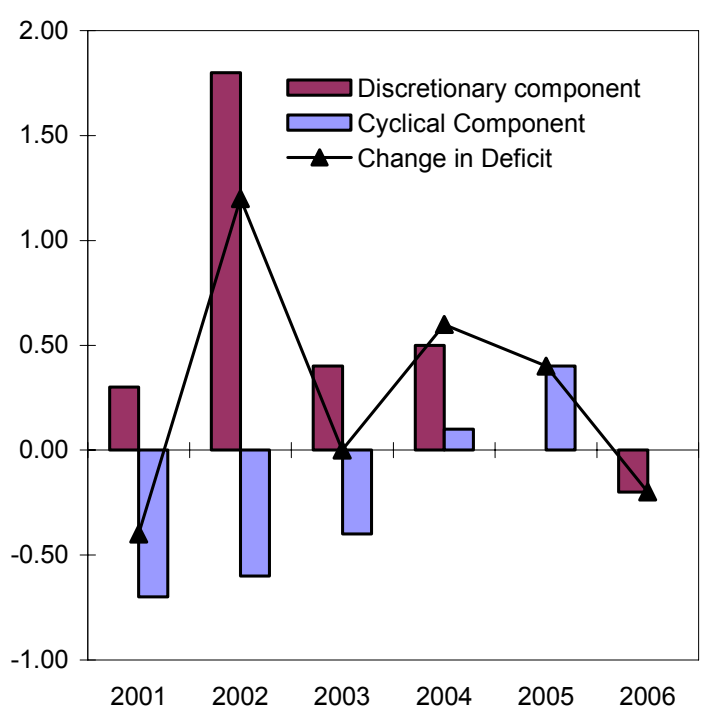

Decomposition of Changes in Cyclically Adjusted Balance (In percent of GDP)

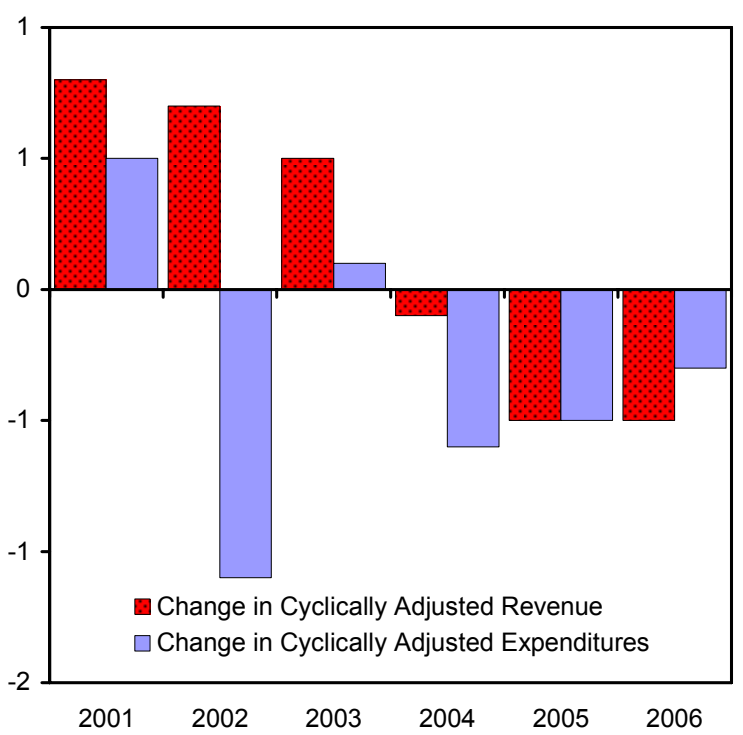

Source: AMECO; Slovene authorities; and staff calculations. 
107. Over the next few years, Slovenia also plans to implement an ambitious revenue consolidation plan while lowering the structural deficit. The authorities envisage reducing the structural deficit to 1 percent of GDP by 2009 and to a structural balance by 2011 . Concurrently, it is anticipated that revenues will decline by almost 4 percent of GDP, from 45.8 percent of GDP in 2005 to 41.7 percent of GDP in 2009, of which about 3 percent of GDP can be attributed to the decline in the tax burden. At the same time, expenditures are projected to be lowered by $4 \frac{1}{2}$ percent of GDP, primarily in the areas of social transfers and gross fixed capital formation. Underlying measures to achieve these targets remain to be fully identified.

108. Over the longer term, age-related spending is expected to add to fiscal pressures and undermine fiscal sustainability. With one of the fastest aging populations in the EU, Slovenia's pension and health care expenditures are expected to increase by around 7 percent of GDP by 2050 under current policies. In the absence of early and decisive measures to reform the pensions and health care systems, fiscal policy will need to be even more conservative to create fiscal space for the age-related spending pressures, and aim for a structural balance or a small surplus (IMF 2006a, Slovenia Stability Report, 2006).

109. The track record shows that medium-term policy targets have been pushed back recurrently. Although the medium term plans in 2004 targeted the deficits to be lowered to less than 1 percent of GDP by 2007, deficit targets in the budget still remain above the 1 percent threshold (Pre-accession Programs, Convergence Program and Stability Programs) for the foreseeable future. These medium-term deficit targets appear to have served as indicative targets for the two-year budgeting process but with substantial revisions in the annual budget process (Ylaoutinen, 2004).
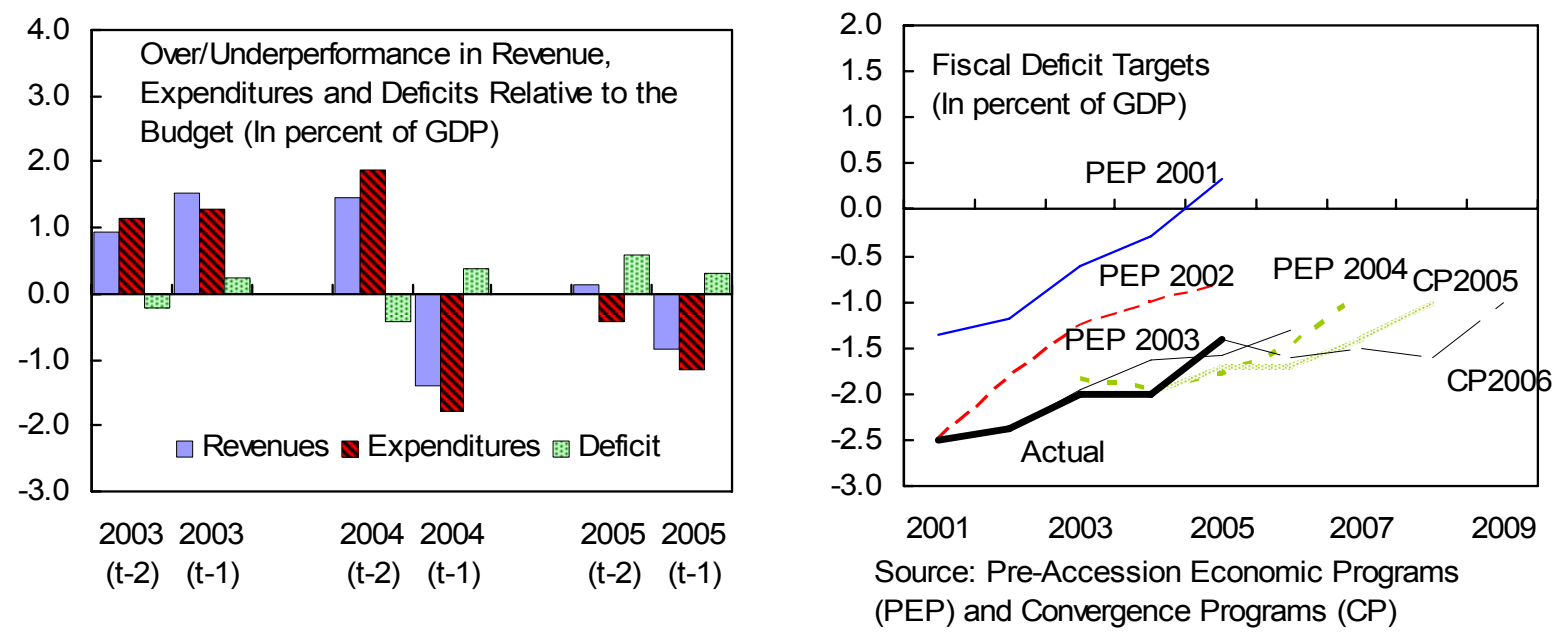

110. While Slovenia has a history of sound fiscal policy implementation, there is also a risk that policies may be relaxed following Euro adoption. The experience with EU members show that fiscal policy discipline weakened and became more expansionary after 
the start of the EMU in 1999, as the countries used the first opportunity to relax their fiscal stance (Von Hagen, 2005, Buti and van den Noord, 2004). This was evident by the fact that once EMU membership was secured, the pattern of political budget cycles, whereby fiscal deficits worsened during election years reemerged as voter's preference for EMU entry no longer served as a restraining factor during budget formulation.

\section{These challenges point to the need for a stronger fiscal framework with due} emphasis on the implementation of the medium term fiscal strategy. In particular, a fiscal responsibility law which embodies a permanent target in the form of a fiscal rule or a full scale medium term budgetary framework with expenditure ceilings would help adhere to fiscal goals. With the tax reforms already in effect, a framework to ensure stronger commitment to the expenditure ceilings would be vital. A clearly defined expenditure-based fiscal framework would lend credibility to the tax reform program as being permanent, allowing efficiency gains. Such a framework would also act as a complementary mechanism to the EU's Stability and Growth Pact.

\section{The Current Fiscal Framework in Slovenia}

\section{As an EU and EMU member, Slovenia has maintained a strong reputation for}

fiscal prudence and discipline. Slovenia's fiscal deficit has stayed safely within the 3 percent margin and the 60 percent debt to GDP threshold under the Stability and Growth Pact. In terms of the quality of budgetary institutions, including its transparency, the Slovene budget fares well relative to the Central European and EMU members. The finance minister's role is ranked particularly strong in the planning and decision-making phases of the budget formulation process while that of the Parliament during the legislative phase is relatively weak. These factors have been shown to contribute to greater fiscal discipline among European countries (Ylaoutinen, 2004).

\begin{tabular}{lc} 
& Open budget index \\
\hline Slovenia & $\mathbf{8 1}$ \\
Bulgaria & 47 \\
Czech Republic & 64 \\
France & 89 \\
Norway & 72 \\
Poland & 74 \\
Romania & 66 \\
Russia & 46 \\
Sweden & 76 \\
United Kingdom & 88 \\
\hline \multicolumn{2}{l}{ Source: Open Budget Initiative, 2006. }
\end{tabular}

\section{Slovenia currently has a two year rolling budgetary framework. The} macroforecasts used for the budget are prepared by Institute for Macroeconomic Analysis and Development (IMAD), an external economic forecasting agency. Revenue forecasts based on these projections, together with the nominal overall expenditure framework, deficit and debt targets and budget priorities for the subsequent four years are presented as the draft Budget Memorandum to the Government by the Prime Minister, the Minister of Finance and the Director of IMAD. Following the guidelines issued by the government, the Ministry of Finance undertakes detailed negotiations with line ministries for the upcoming budget and the subsequent year. The government then sets the disaggregated expenditure ceilings in the second budget session. Following the submission of financial plans and development 
programs by line ministries, the Minister of Finance submits the budget amendment for the upcoming year, the budget for the subsequent budget year, and the Budget Memorandum to the National Assembly.

\section{This unique budgetary framework provides a medium term orientation to the} budget procedures, much akin to a multiannual expenditure framework, but without its automatic countercyclical feature. Since the expenditure ceilings need to be revised in light of changes in macroeconomic circumstances and fiscal policy objectives, this system prevents the functioning of automatic stabilizers embodied in multiyear expenditure ceilings (Kraan and Wehner, 2005). While this system, in principle, allows more room for a countercyclical role for expenditure policy, the high share of non-discretionary spending in the budget structure limits this possibility (IMF, 2006). Nevertheless, it has been argued that by providing a longer term horizon for budget negotiations and limiting the scope of amendments to the budget in the upcoming year, the two year budgeting system ensures that requests for additional spending are narrowed down substantially contributing to the budgetary discipline.

\section{The authorities are currently discussing introduction of a fiscal rule focused on}

an annual deficit rule. Such a rule would require that in case of revenue underperformance, expenditures would need to be reduced to ensure compliance with the annual deficit target. An expenditure rule is not considered viable given the likely conflict with adherence to an a annual deficit target. Proposals also include a golden rule that would allow borrowing for investment or amortization of debt. While a revenue rule exists for local governments that limits borrowing to less than 20 percent of revenues of the previous year, proposals are also being considered on ways to extend the rule for the soon-to-be-formed regional governments.

\section{Experience with Fiscal Rules in the EU}

\section{Several $\mathbf{E U}$ countries have fiscal rules in addition to the debt and deficit rules of} the SGP (EDP) (Table 1). These national fiscal rules are stricter than the SGP rules and often take the form of an internal pact between the different levels of government reflecting differing economic circumstances, government structures, and public preferences. For instance, countries with coalition governments adopt a contract-based approach to budgetary decision-making whereas those with majoritarian governments have decision-making structures that are centralized and delegated to the finance minister. Stricter fiscal rules are more prevalent under the former system (Hallerberg, Strauch and von Hagen, 2004). Over the past two decades, the restrictiveness and coverage of national fiscal rules have increased in the EU (European Commission, 2006). 
Table 1. Deficit Target Rules in Select EU Countries.

\begin{tabular}{|c|c|c|c|}
\hline & & Fiscal objective & Planning horizon \\
\hline Denmark & $\begin{array}{l}\text { Medium term fiscal } \\
\text { strategy, } 2001\end{array}$ & $\begin{array}{l}\text { Average structural budget surplus of } 1.5-2.5 \\
\text { percent of GDP from } 2003 \text { to } 2010 \text {. }\end{array}$ & $\begin{array}{l}\text { Multiannual (till } \\
\text { 2010) }\end{array}$ \\
\hline Finland & $\begin{array}{l}\text { Medium term objectives, } \\
2004\end{array}$ & $\begin{array}{l}\text { Reach balanced structural deficit by } 2007 \text { for } \\
\text { central government, cap on central } \\
\text { government primary expenditure excluding } \\
\text { unemployment benefits; decline in debt ratio }\end{array}$ & $\begin{array}{l}\text { Four years on a } \\
\text { rolling basis }\end{array}$ \\
\hline Germany & $\begin{array}{l}\text { Domestic Stability Pact, } \\
\text { 2002, Constitution }\end{array}$ & $\begin{array}{l}\text { Golden rule for the federal government under } \\
\text { the Constitution. Federal and subnational } \\
\text { governments should aim for a balanced } \\
\text { budget }\end{array}$ & Permanent \\
\hline Netherlands & & $\begin{array}{l}\text { Below } 3 \text { percent of GDP under normal } \\
\text { economic fluctuations }\end{array}$ & $\begin{array}{l}\text { Four years at } \\
\text { beginning of } \\
\text { coalition period }\end{array}$ \\
\hline Spain & Budget Stability Law, 2003 & $\begin{array}{l}\text { Balance budget or surplus at all levels of } \\
\text { government. Temporary deviations allowed } \\
\text { with plans to restore balance within two to } \\
\text { three years. }\end{array}$ & $\begin{array}{l}\text { Multiannual ( } 3 \\
\text { years) }\end{array}$ \\
\hline Sweden & Fiscal Budget Act, 1997 & $\begin{array}{l}\text { Surplus of } 2 \text { percent of GDP over the business } \\
\text { cycle }\end{array}$ & Three years \\
\hline Switzerland & Constitution & Balanced structural budget & Permanent \\
\hline $\begin{array}{l}\text { United } \\
\text { Kingdom }\end{array}$ & Finance Act, 1998 & $\begin{array}{l}\text { Golden Rule: balanced current account over } \\
\text { the cycle }\end{array}$ & $\begin{array}{l}\text { Three years on } \\
\text { a two year } \\
\text { rolling basis }\end{array}$ \\
\hline
\end{tabular}

Source: IMF (2006), European Commission (2006).

\section{Numerical fiscal rules help promote fiscal discipline provided there exists}

sufficient political commitment. Fiscal rules act as a permanent constraint on the government to help contain a deficit bias arising from the 'common pool' problem-a failure to internalize the cost of programs by individuals or interest groups when the cost is borne by a wider group. This phenomenon is known to be more acute during cyclical upswings, in fragmented political systems with a 'commitment' approach of budgeting, and in case of governments that face electoral uncertainty leading to a myopic policy horizon. Entry into a monetary union can also increase this problem as the cost of fiscal spending is borne among a wider group of countries. Empirical evidence is in favor of deficit reduction following introduction of a rule, although this may be subject to endogeneity bias, i.e. enactment of fiscal rule already reflects political will to consolidate (Debrun, 2007).

118. However, numerical deficit rules have some drawbacks. The main issues include:

- Rigid annual deficit stance can lead to a procyclical stance. Hence, deficit targets are often set in structural terms or as averages over a medium term horizon. But this is difficult to calculate for a transition economy particularly when the nature of shocks are 
difficult to identify on a short run basis. This, in turn, also creates difficulties in interpretation for setting expenditure ceilings.

- Strict adherence to the deficit rule could lead to a poor quality of fiscal adjustment. Frequently, measures fall on discretionary expenditures that are easiest to cut such as capital expenditures rather than spending based on efficiency consideration. Hence, a number of countries have introduced a 'golden rule' that excludes investment spending and targets current balance.

- To meet the deficit rule, governments can resort to creative accounting and circumventions through off-budget activity, cash/accrual classification, etc.

- Lack of enforceability is a major challenge at the central and general government level. Hence, such rules are more common at local level governments (European Commission, 2006). The main enforcement mechanism for fiscal rules at higher levels of government is through reputational costs, presuming voter awareness and preference for the rule.

\section{Lessons from country experiences suggest that fiscal rules can be more successful under certain preconditions (IMF, 2005a). Fiscal rules require wide-ranging political consensus about the need for prudent fiscal policies. The fiscal institutional framework, including budgetary institutions and expenditure management, should be sufficiently developed. Fiscal rules should be well defined, simple, transparent, and monitorable. Independent monitoring and credible enforcement mechanisms are important. The coverage of the fiscal rule needs to be broad-based and the degree of hardness of the fiscal rule affects fiscal performance. This is more evident in case of coalition governments.}

\section{Fiscal rules are often complemented by medium term budgetary frameworks} (MTBF) with underlying expenditure ceilings. A medium term budgetary framework defines a legal framework regulating formulation of multi-year fiscal policies in order to promote transparency and accountability. An expenditure rule, in the form of a ceiling, introduces a countercyclical feature to the budgeting system as it allows the automatic stabilizers to operate fully on the revenue side. The main characteristics of MTBFs and the underlying expenditure rule (Table 2) vary considerably. Some key features are in terms of the length of the time horizon; and whether the time horizon is fixed or rolling. Other important dimensions are the flexibility with which the ceilings are updated and whether the ceilings are defined in constant or current prices. The latter, in turn, depends on the time horizon of the expenditure ceilings: over shorter horizons, nominal rules help fiscal stabilization, but over longer horizons this will depend upon the nature of inflation 


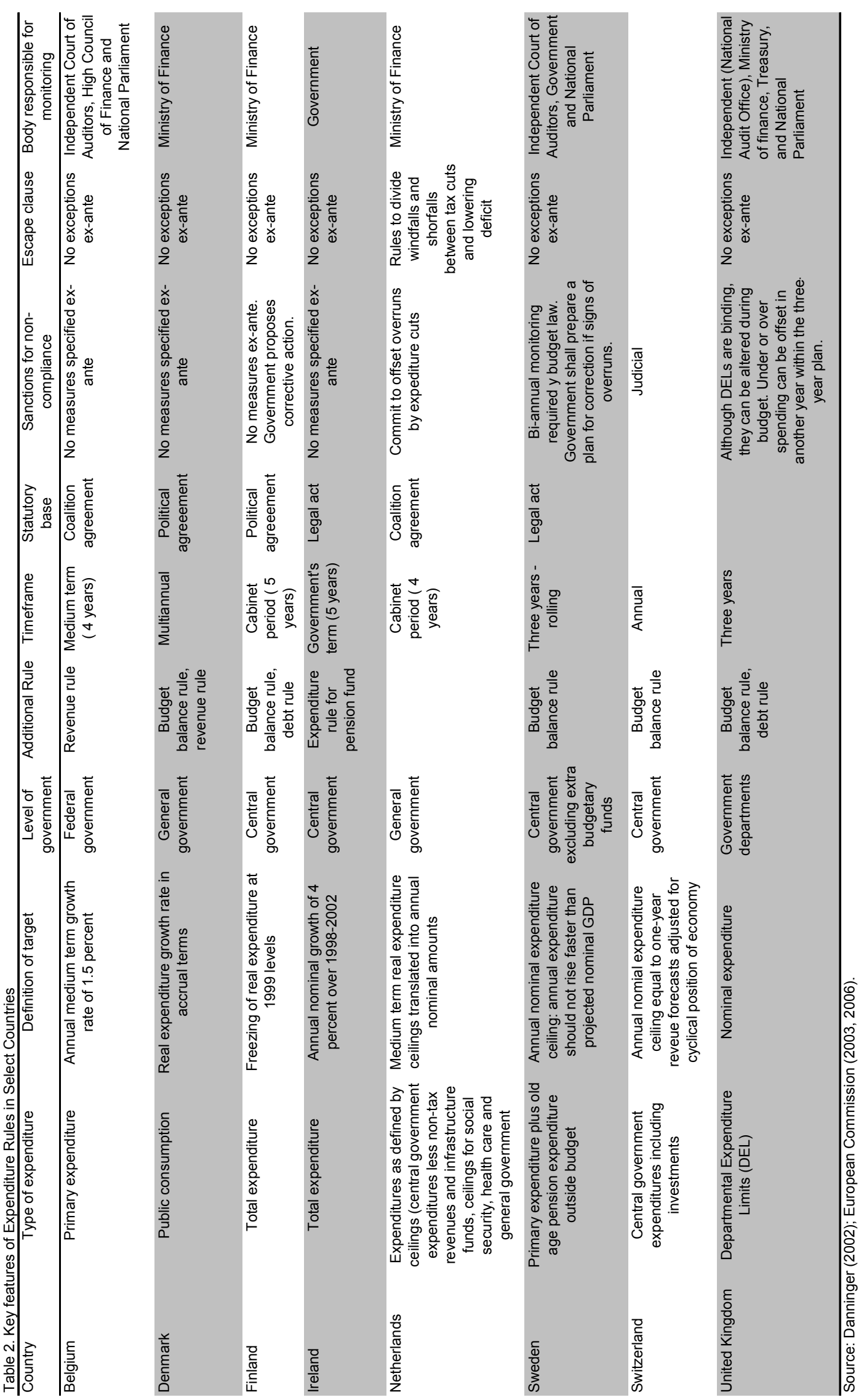


forecast errors. The coverage of expenditure ceilings - on aggregate spending versus subcategories such as discretionary expenditures or current spending - is also an important consideration. The theoretical foundations of spending rules are similar to cyclically-adjusted deficit rules, but are more practical due to its transparency (Mills and Quinet, 2002).

121. Provided sufficient political will exists, MTBFs have played an important role in countries that have undertaken large fiscal adjustments. In the absence of political commitment, MTBF has had little impact on annual budget formulation. A MTBF that is not fully integrated into the annual budget formulation process tend to remain ineffective. Country experiences also suggest that the underlying structural reforms need to be wellidentified. Ceilings imposed only on total expenditure tend to be breached. Thus, exclusions of hard to control items such as interest and cyclical items such as unemployment benefits are common. Regular reviews of budget programs and projections help promote more realistic medium-term cost projections. Furthermore, official projections tend to be biased, especially if there is no obligation to explain ex post to the public the difference between projections and outturns.

\section{To enhance the credibility of the MTBF, a few countries have established}

independent fiscal institutions. Such institutions help to limit time-inconsistent behavior of policymakers by monitoring fiscal policy and making them more transparent to the public, thereby increasing the cost of fiscal profligacy. Given their independent expertise, these institutions serve as a guardian of fiscal policy objectives that are set ex-ante by the Parliament.

\section{The model for an independent fiscal institution varies considerably by country}

(Table 3) and their roles generally include:

- Independent monitoring and analysis of fiscal policy developments. These institutions also make normative statements on fiscal policy implementation including on adherence to the rules, which facilitates greater public debate on fiscal policy developments and objectives and evaluation of government's performance;

- Preparation of macroeconomic forecasts and assumptions for the annual and MTBFs.

- Enforcement of sanctions on a non-discretionary basis. An independent monitoring and assessment of the compliance of rules is crucial to maintain the credibility of the fiscal framework.

124. Survey data in the EU suggest that the presence of independent fiscal institutions has led to more transparency and public debate $(\mathrm{EC}, 2006)$. This has contributed to fiscal discipline by improving incentives for the government to adhere to the fiscal rule. The legal restraints imposed by these institutions on fiscal policymaking and the legal guarantees on their independence have increased the perceived impact on fiscal performance. While it is 
unclear if fiscal institutions affect fiscal performance, there is empirical evidence that it serves as a signaling device for a commitment to fiscal discipline (Debrun, 2007).

Table 3. Key features of Independent Fiscal Institutions in Select Countries

\begin{tabular}{|c|c|c|c|c|}
\hline Country & Institution & $\begin{array}{l}\text { Forecasts and } \\
\text { Projections of }\end{array}$ & $\begin{array}{l}\text { Independent Analysis of } \\
\text { Fiscal Policy }\end{array}$ & $\begin{array}{l}\text { Normative } \\
\text { Reports/Recommendations on }\end{array}$ \\
\hline Belgium & $\begin{array}{l}\text { National Account } \\
\text { Institute, High } \\
\text { Council of Finance }\end{array}$ & $\begin{array}{l}\text { Macroeconomic } \\
\text { forecasts }\end{array}$ & $\begin{array}{l}\text { Monitoring of budget } \\
\text { implementation, analysis } \\
\text { of whether budgetary } \\
\text { plans and outcomes are } \\
\text { in line with fiscal rules }\end{array}$ & $\begin{array}{l}\text { Proposals for changes in } \\
\text { budget plans, normative } \\
\text { statement on respect of fiscal } \\
\text { rules, recommendations in case } \\
\text { of slippages }\end{array}$ \\
\hline Denmark & $\begin{array}{l}\text { Danish Economic } \\
\text { Council }\end{array}$ & $\begin{array}{l}\text { Forecasts } \\
\text { (macroeconomic, } \\
\text { revenue, expenditure, } \\
\text { balance, debt, long- } \\
\text { term) }\end{array}$ & $\begin{array}{l}\text { Monitoring and analysis of } \\
\text { budget }\end{array}$ & $\begin{array}{l}\text { Proposals for changes in } \\
\text { budget plans, normative } \\
\text { statement on respect of fiscal } \\
\text { rules, recommendations in case } \\
\text { of slippages }\end{array}$ \\
\hline Netherlands & $\begin{array}{l}\text { Bureau of } \\
\text { Economic Policy } \\
\text { Analysis }\end{array}$ & $\begin{array}{l}\text { Forecasts } \\
\text { (macroeconomic, } \\
\text { revenue, expenditure, } \\
\text { balance, debt, long- } \\
\text { term) }\end{array}$ & $\begin{array}{l}\text { Budget analysis, } \\
\text { monitoring of budget } \\
\text { implementation, analysis } \\
\text { of whether budgetary } \\
\text { plans and outcomes are } \\
\text { in line with fiscal rules, } \\
\text { estimates of impact of } \\
\text { policy measures }\end{array}$ & \\
\hline Spain & Court of Auditors & & $\begin{array}{l}\text { Monitoring of budget } \\
\text { implementation, analysis } \\
\text { of whether budgetary } \\
\text { plans and outcomes are } \\
\text { in line with fiscal rules }\end{array}$ & $\begin{array}{l}\text { Normative statement on respect } \\
\text { of fiscal rules, } \\
\text { recommendations in case of } \\
\text { slippages (ex-post basis) }\end{array}$ \\
\hline Sweden & $\begin{array}{l}\text { National Institute of } \\
\text { Economic } \\
\text { Research }\end{array}$ & $\begin{array}{l}\text { Forecasts } \\
\text { (macroeconomic, } \\
\text { revenue, expenditure, } \\
\text { balance, debt, long- } \\
\text { term) }\end{array}$ & $\begin{array}{l}\text { Monitoring and analysis of } \\
\text { budget }\end{array}$ & $\begin{array}{l}\text { Normative statement on respect } \\
\text { of fiscal rules }\end{array}$ \\
\hline United Kingdom & $\begin{array}{l}\text { National Audit } \\
\text { Office }\end{array}$ & & $\begin{array}{l}\text { Analysis of budget } \\
\text { assumptions }\end{array}$ & $\begin{array}{l}\text { Normative statement on respect } \\
\text { of fiscal rules in budget plans }\end{array}$ \\
\hline
\end{tabular}

Source: European Commission (2006).

\section{E. Policy Issues for Slovenia}

\section{Fiscal rule}

125. Rules targeting a cyclically adjusted deficit may be considered. Although estimates of potential output and the needed cyclical adjustment are subject to a high degree of uncertainty, particularly in a transition economy, an agreed method of calculating the potential output by an independent institution could form the basis for estimating cyclically adjusted revenue or deficit to be used for policy formulation and assessment. While basing formal rules on them may be challenging, fiscal policy discussions should, at the minimum, incorporate adequate attention to the development of the cyclically adjusted revenues and expenditures. 
126. Long term fiscal sustainability considerations would need to guide the deficit target underlying the fiscal rule. A number of studies have highlighted the challenges of fiscal sustainability arising from aging pressures, suggesting the need to run fiscal surpluses (Stability Report, 2006). The medium term fiscal targets thus need to incorporate the longer term considerations for debt sustainability, particularly as pension reforms fail to take hold. The MTBF would serve as an effective communication device to analyze the implications of delaying reforms in age-related expenditures.

\section{Medium term budgeting framework}

\section{Improvements in the MTBF could be considered to spell out the reform} programs in a detailed framework while simplifying the budgetary procedures. It would include specific reform measures within a prespecified time horizon that would achieve the deficit targets under the rule along with estimates of savings from these measures. The time horizon of the MTBF could be extended to match the electoral cycle which would lend credibility to the fiscal strategy of the incoming government and raise the reputational costs of failing to adhere to it. In addition, the expenditure ceilings could be specified at a more aggregated level for the budget for the second year and beyond which would also minimize the need for negotiating and amending the second year budgets at a detailed line item level in subsequent budget cycles.

\section{An expenditure rule, combined with a MTBF framework that is based on the} rule for the cyclically adjusted deficit, could help promote fiscal consolidation. This could provide the necessary flexibility to conduct countercyclical fiscal policies by letting the automatic stabilizers work on the revenue side. The expenditure ceilings could be set on the basis of a spending review that analyses the objectives and performance of spending areas. To safeguard the medium-term fiscal targets, the law could include a requirement to make increases in mandatory spending program budget-neutral through offsetting measures.

129. To safeguard concerns that productive spending on infrastructure can be cut to meet the rule, a 'golden rule' could be considered. This prevents a poor quality of fiscal adjustment whereby expenditure cuts fall on areas which are more productive but are easiest to cut due to more discretion. However, such exclusions from a fiscal rule have also been criticized on the grounds that returns on public investment spending do not necessarily ensure a return higher than the cost of borrowing. Furthermore, the distinction between capital and current spending is not always very clear, allowing ways of circumventing the ceilings on current spending.

\section{Independent assessment of fiscal trends and budget plans and implementation}

130. Independent assessment of fiscal trends could enhance the credibility of a new fiscal framework. In Slovenia, Institute for Macroeconomic Analysis and Development (IMAD) already provides macroeconomic assumptions and projections for the underlying 
budgets (such as growth, inflation, and market interest rates). Analysis of macroeconomic assumptions since 1995 do not suggest evidence of a systematic bias in macroeconomic projections. Nevertheless, it may be prudent to consider a cautionary bias by applying a prudential margin to its growth forecasts for budgetary assumptions as practiced in Canada and Unites Kingdom. To strengthen the role of independent institutions, in line with international practices, additional roles could also be considered. These include:

- $\quad$ Assessment of medium- and long-term fiscal trends by producing fiscal baseline projections (based on unchanged policies and legislation);

- $\quad$ The yield of new fiscal measures in annual or medium-term budgets;

- A normative assessment of fiscal policy implementation, including on adherence to fiscal strategy and rules;

- $\quad$ The factors responsible for deviations from annual and medium-term budget targets.

The purposes of such assessments would be to enhance transparency and improve the methodology of projecting macroeconomic developments, budget revenue and expenditure; and eliminate political bias in the budget formulation process. To this end, the independence of the institution could be strengthened by requiring it to report its assessment directly to Parliament, readily available to the public.

\section{F. Conclusions}

\section{Slovenia faces significant challenges in reforming fiscal policy in the coming} years. For fiscal policy to be an effective instrument for economic stabilization, increased budgetary flexibility particularly on the expenditure side will be required. Slovenia also needs to implement significant expenditure consolidation to meet its medium-term fiscal targets while accommodating tax reforms. In light of long-run sustainability concerns, fiscal policy will need to aim for a structural balance or a surplus, if systemic pension and healthcare reforms are not addressed soon. A stronger fiscal framework that incorporates these fiscal targets will help to signal the commitment to the objectives of the fiscal reform package, specify the underlying measures, and thus enhance the credibility of the mediumterm fiscal goals. Against this background, the paper examined considerations for strengthening the fiscal framework in Slovenia.

\section{Strengthening the medium term budgetary framework with underlying fiscal} rules and greater transparency on adherence to the fiscal objectives could help enhance fiscal discipline. Slovenia's fiscal deficit targets that are anchored on debt-sustainability analysis need to be better integrated in the medium term budgetary framework. Introducing a fiscal rule for expenditures that is based on a structural deficit target could impose more fiscal discipline while allowing short term flexibility through revenue stabilizers. An increased role for independent monitoring of budgetary plans and an assessment of the 
budget implementation against the stated objectives could allow more public debate and voter awareness, helping to enforce the framework and preserve fiscal discipline. 


\section{References}

Buti, Marco, and Paul van den Noord, 2004, "Fiscal Policy in EMU: Rules, Discretion, and Political Incentives,” Economic Papers 206 (Brussels: European Commission).

Danninger, Stephan, 2002, “A New Rule: The Swiss Debt Brake,” IMF Working Paper 02/18. (Washington: International Monetary Fund).

Debrun, Xavier, 2007, “Tying Hands Is Not Commitment: Can Fiscal Rules and Institutions Really Enhance Fiscal Discipline?” Bruegel Working Paper 01/2007 (Brussels: Bruegel).

European Commission, 2003, "Expenditure Rules in EU Member States," in Public Finance in EMU, 2003 (Brussels: European Commission).

European Commission, 2006, "National Numerical Fiscal Rules and Institutions for Sound Public Finances," in Public Finance in EMU, 2006 (Brussels: European Commission).

Hallerberg, Strauch and von Hagen, 2004, "The Design of Fiscal Rules and Forms of Governance in European Union Countries," ECB Working Paper No. 419 (Frankfurt: European Central Bank).

IMF, 2005a, Fiscal Responsibility Laws, unpublished, Washington DC.

IMF, 2005b, Cyclicality of Fiscal Policy and Cyclically Adjusted Fiscal Balances, unpublished, Washington DC.

IMF, 2005c, Promoting Fiscal Discipline Over the Business Cycle, unpublished, Washington DC.

IMF, 2006a, "Slovenia: Selected Issues,” IMF Country Report No. 06/275 (Washington DC: International Monetary Fund).

IMF, 2006b, “Poland: Selected Issues," IMF Country Report No. 06/XXX (Washington DC: International Monetary Fund).

Kraan, Dirk-Jan, and Joachim Wehner, 2005, "Budgeting in Slovenia," OECD Journal on Budgeting, Volume 4, Issue 4 (Paris: Organization of Economic Cooperation and Development). 
Mills, Philippe and Alain Quinet, 2002, "How to Allow the Automatic Stabilizers to Operate Fully? A Policymaker's Guide for EMU Countries," in The Behavior of Fiscal Authorities-Stabilization, Growth and Institutions, pp. 115-29, ed. by M. Buti, J. von Hagen and C. Martinez-Mongay (Brussels: European Commission).

Ministry of Finance of the Republic of Slovenia, 2006, "Stability Program 2006," (Ljubljana: Ministry of Finance).

Von Hagen, Jurgen, 2005, "Fiscal Rules and Fiscal Performance in the EU and Japan," CEPR Discussion Papers 5330 (London: Center for Economic Policy Research).

Ylaoutinen, Sami, 2004, "Fiscal Frameworks in the Central and Eastern European Countries," Discussion Paper No. 72, (Helsinki: Central Bank of Finland). 